\title{
Vegetable Cultivar Descriptions for North America \\ List 27 \\ 2013
}

\author{
Edited by Todd C. Wehner and Beiquan Mou \\ North Carolina State University, Raleigh, NC 27695-7609 \\ (todd_wehner@ncsu.edu) \\ and \\ USDA-ARS, 1636 East Alisal Street, Salinas, CA 93905 \\ (beiquan.mou@ars.usda.gov)
}

Crop listings: asparagus, bean-dry, bean-green, beet, broccoli, cabbage, cabbage-Chinese, carrot, cauliflower, celery, collard, cucumber, eggplant, endive, herbs-parsley, leek, lettuce, melon, okra, onion, pea-green, pepper, pumpkin, radish, rhubarb, soybean, spinach, squash, sweetcorn, Swiss chard, tomato, turnip, watermelon.

This list of the North American vegetable cultivars was developed using the database of cultivars registered with the American Seed Trade Association, as well as published descriptions from scientific journals, seed catalogs, and websites of seed companies. Assistant editors responsible for each crop were instructed to obtain as much information as possible about the cultivars available to North American growers. The crop species are listed alphabetically, with cultivars listed alphabetically within each of those.

The information about each cultivar is presented in a standard format that includes the cultivar name, experimental designation, breeder, vendor, parentage, plant characteristics, disease and other resistances, similar cultivars, areas of adaptation, plant variety protection information, reference information, and year of release. In many cases, complete information was not available for the cultivars included in the list.

Previous vegetable cultivar lists have been published (1-26) in this journal, and its predecessor.

1. Anonymous. 1954. New vegetable varieties list I. Proc. Amer. Soc. Hort. Sci. 63:503-525.

2. Anonymous. 1955. New vegetable varieties list II. Proc. Amer. Soc. Hort. Sci. 65:493-511.

3. Anonymous. 1956. New vegetable varieties list III. Proc. Amer. Soc. Hort. Sci. 67:587-609.

4. Anonymous. 1957. New vegetable varieties list IV. Proc. Amer. Soc. Hort. Sci. 69:574-587.

5. Anonymous. 1958. New vegetable varieties list V. Proc. Amer. Soc. Hort. Sci. 71:591-600.

6. Anonymous. 1960. New vegetable varieties list VI. Proc. Amer. Soc. Hort. Sci. 75:842-850.

7. Anonymous. 1961. New vegetable varieties list VII. Proc. Amer. Soc. Hort. Sci. 77:648-653.

8. Anonymous. 1963. New vegetable varieties list VIII. Proc. Amer. Soc. Hort. Sci. 82:652-660.

9. Anonymous. 1964. New vegetable varieties list IX. Proc. Amer. Soc. Hort. Sci. 84:665-673

10. Minges, P.A. 1965. New vegetable varieties list X and XI Proc. Amer. Soc. Hort. Sci. 86:824-845.

11. Minges, P.A. 1966. New vegetable varieties list XII. Proc. Amer. Soc. Hort. Sci. 88:718-726.

12. Minges, P.A. 1966. New vegetable varieties list XIII. Proc. Amer. Soc. Hort. Sci. 88:727-732.

13. Minges, P.A. 1967. New vegetable varieties list XIV. Proc. Amer. Soc. Hort. Sci. 90:567-569.

14. Minges, P.A. 1968. New vegetable varieties list XV. Proc Amer. Soc. Hort. Sci. 92:823-840.

Individuals knowing of new cultivars to add to the list, or corrections to be made in the published lists are encouraged to contact Beiquan Mou. The assistance of Robert Falasca (American Seed Trade Association), and Julia Jenkins (North Carolina State University) is gratefully acknowledged.
15. Barnes, W.C. 1969. New vegetable varieties list XVI. HortScience 4:65-69.

16. Barnes, W.C. 1970. New vegetable varieties list XVII. HortScience 5:146-149.

17. Barnes, W.C. 1971. New vegetable varieties list XVIII. HortScience 6:124-127.

18. Lower, R.L. 1973. New vegetable varieties list XIX. HortScience 8:465-470.

19. Lower, R.L. 1975. New vegetable varieties list XX. HortScience 10:467-470.

20. Tigchelaar, E.C. 1980. New vegetable cultivar list XXI. HortScience 15:565-578.

21. Tigchelaar, E.C. 1986. New vegetable cultivar list 22. HortScience 21:195-212.

22. Tigchelaar, E.C. 1991. New vegetable cultivar list 23. HortScience 26:343-357.

23. Wehner, T.C. 1999. Vegetable cultivar descriptions for North America, list 24, 1999. HortScience 34:763-806.

24. Wehner, T.C. 1999. Vegetable cultivar descriptions for North America, list 25, 1999. HortScience 34:957-1012.

25. Wehner, T.C. 2002. Vegetable cultivar descriptions for North America, list 26, 2002. HortScience 37:15-78.

\section{ASPARAGUS \\ Todd C. Wehner \\ Department of Horticultural Science \\ North Carolina State University \\ Raleigh, NC 27695-7609}

Jersey Knight - Breeder and vendor: Jersey Asparagus Farms. Parentage: F1 hybrid. Characteristics: all male (androecious); adapted to temperate and warm climates; 7 days later than Jersey Supreme; high yield; medium to large spear diameter (control by spacing); green spears with slightly purple bracts under cool conditions. Resistance: rust. 2002.

Jersey Supreme - Breeder and vendor: Jersey Asparagus Farms. Parentage: F1 hybrid. Characteristics: all male (androecious); adapted to temperate warm and cool climates; early maturity; high yield; medium to medium large spear diameter (control by spacing); green spears with slightly purple bracts under cool conditions. Resistance: rust. 2002.

\section{BEAN-DRY}

Black Velvet (EX 08520643) - Breeder and vendor: Seminis Vegetable Seeds. Parentage: inbred line. Characteristics: upright indeterminate habit; processing type; black bean with a nice erect plant and full season maturity (105-110 days); seed size plumper 
than standard cultivars; canned quality as good or better than that of standard cultivars; yields consistently good. Resistance: Bean common mosaic virus ( $I$ gene), anthracnose (race Alpha). Similar: Midnight. Adaptation: NAFTA. 2004.

Chianti (XP 08530759) - Breeder and vendor: Seminis. Parentage: open pollinated. Characteristics: cranberry bean; upright determinate plant type, matures in 90 days, processor type, better than any current determinate bush cranberry type. Resistance: Bean common mosaic ("I" gene). Similar: Michigan Improved Cran, Dolly. Adaptation: NAFTA — processor dry edible bean areas. 2005.

Dolly (XP 8504118) - Vendor: Seminis Vegetable Seeds-Asgrow. Parentage: open pollinated. Characteristics: late maturing, large seed size bush borlotti for the dry seed market that exports to Italy; good yields and seed size makes this cultivar very attractive; good color contrast. Resistance: BCMV, beet common mosaic. Similar: Cran 09, ASI Taylor's, Hooter. Adaptation: Canada, Michigan. 2002.

Pink Panther (EX 08590462) - Breeder and vendor: Seminis Vegetable Seeds-Asgrow. Parentage: inbred line, parentage not disclosed. Characteristics: light red kidney type with improved grain quality, good processed quality, high yield, early maturity, and good plant type. Resistance: bean common mosaic Virus (I gene). Similar: Cal Early Light Red, Foxfire. Adaptation: Northeast U.S. 2003.

\section{BEAN-GREEN}

Ambra (HMX 0104) - Breeder: Robert Gehin. Vendor: Harris Moran. Parentage: open pollinated. Characteristics: 52 day relative maturity fresh market green bean; medium green color, 6 inch, round, 4 sieve pods, high to mid pod placement, upright plant habit; darker pod color and more erect plant habit than Hialeah; white seeded. Resistance: BCMV, beet curly top virus. Similar: Hialeah. Adaptation: U.S. 2002.

Cadillac (RS 1260, EU 11666 in Europe) - Breeder and vendor: Seminis Vegetable Seeds. Parentage: open pollinated. Characteristics: medium late maturity for processor use, perhaps also fresh market use; end product grade $=6$ and $9 \mathrm{~mm}$; pod length is $10-11 \mathrm{~cm}$. Resistance: anthracnose, halo blight, bean common mosaic. Similar: Remeo, Sigma. Adaptation: NAFTA (processing and fresh market), Europe (processing). PVP applied for. 2004.

Caprice (HMX 0944)-Breeder: Steve Magnuson. Vendor: Harris Moran. Parentage: open pollinated. Characteristics: green bean type; 56 days to maturity; upright plant habit; high pod set; sieve size 4; pods are medium dark green and 5.5 inches long. Resistance: bacterial brown spot. Adaptation: home garden, U.S. 2003.

Charon-Breeder and vendor: Syngenta Seeds, Inc./Rogers Brand. Characteristics: long (6-inch), dark-green pods are very refined and have shown good yield potential in about 58 days. Resistance: superb disease package; resistance to bean common mosaic virus; tolerance to bacterial brown spot, halo blight, and curly top. Adaptation: adapted to a variety of locations. 2005.

Concesa (HMX 8996)—Breeder: Steve Magnuson. Vendor: Harris Moran. Parentage: open pollinated. Characteristics: bush green bean type; 55 day maturity; strong upright plant habit, high pod set and strong seedling vigor; pods dark green, 6.0 inches long, 3 to 4 sieve. Resistance: BCMV, rust (races $38,53,72$ ) and beet curly top virus. Adaptation: U.S. 2002.

Dart (FM 658) - Breeder: Robert Gehin. Vendor: Harris Moran. Parentage: open pollinated. Characteristics: 52-day maturity; medium dark green pods, 5.1 inches long; pod size distribution at processing maturity: 20\% 1-3; 60\% 4; 20\% 5-sieve. Resistance: BCMV, I gene. Adaptation: processing; U.S. US patent \#6,211,441 B1. 2002.

Dusky-Breeder and vendor: Syngenta Seeds, Inc./Rogers Brand. Characteristics: produced long dark green pods; bush tends to be upright with good cover helping to produce straight, smooth beans. Adaptation: Midwest and Northeast. 2005.

Excaliber (XP 08190505)—Breeder and vendor: Seminis Vegetable Seeds-Asgrow. Parentage: open pollinated. Characteristics: intermediate sieve, dual purpose type, pods $13 \mathrm{~cm}$ long, very dark green, high quality; for processing and fresh market. Resistance: bean common mosaic virus ("I" gene), anthracnose (races Delta, Gamma), intermediate resistant halo blight. Similar: Medinah, Slenderpack. Adaptation: NAFTA — northeast and northwest U.S. PVP application \#200300181. 2003.

Festina-Breeder and vendor: Seminis Vegetable Seeds. Characteristics: features very dark-green, glossy pods, matures early to mid-season, and is suited to machine and hand harvest with high yield; plant is vigorous, heat tolerant, and upright with concentrated sets medium-high on the plant. Resistance: bean common mosaic virus. 2002.

Firstmate (XP 07715813)—Breeder and vendor: Seminis. Parentage: OP. Characteristics: medium sieve size garden bean with attractive plant; sets a consistent set of deep green, straight, refined pots. Similar: Teseo, Minuette. Resistance: Bean common mosaic virus "I" gene (BCMV); intermediate resistance to Beet curly top virus (BCTV), Pseudomonas springae pv. syringae (BBS/Bacterial brown spot). Adaptation: NAFTA-Northeast U.S Processor. 2005.

Greenback (SSC 1202)—Breeder and vendor: Shamrock Seed Co. Parentage: open pollinated. Characteristics: a highly productive bush bean that produces a dark green, upright bush with high pod placement; the round to oval pods are medium green in color and range from 6 to 6.5 inches in length; suited for mechanical harvest; developed for fresh market. Similar: Green Crop. Adaptation: U.S. bean growing areas. 2003.

HMX 5991 - Breeder and vendor: Harris Seeds. Characteristics: gourmet quality, 60-day fresh market bush green bean; 5 - to $51 / 2$ inch pods have dark green color, 2 to 3 sieve size, and are set high on compact and erect bush plants. 1998.

Leon-Breeder and vendor: Syngenta Seeds, Inc./Rogers Brand. Characteristics: in winter trials, has provided the advantage of good field-holding ability and a longer harvest of smooth, round pods. Resistance: certain races of common mosaic virus. Adaptation: excellent for winter plantings in Florida. 2005.

Lynx (XP 8104379) - Vendor: Seminis Vegetable SeedsAsgrow. Parentage: open pollinated. Characteristics: bush type; high quality, glossy medium size pods on a compact, but upright plant; $13 \mathrm{~cm}$ pods are slightly darker and shorter than Bronco $(13.7 \mathrm{~cm})$; shorter and darker pods will result in less breakage and should provide excellent high quality produce in the bag; compact upright plant will benefit the markets that suffer with large plant growth because of planting time and/or high soil fertility. Resistance: Bean common mosaic (I gene). Similar: Bronco, Opus, Festina. Adaptation: northeast U.S., fresh market. PVP application \#200200097. 2002.

Navarro (FM 184) - Breeder: Robert Gehin. Vendor: Harris Moran. Parentage: open pollinated. Characteristics: 54 day Bush Romano type with medium dark green 6.0-6.5 inch pods; like Primo but better plant type and thinner pods; fleshy pods and excellent shape. Similar: Primo. Adaptation: U.S. 2002.

Preakness (XP 8104098) — Vendor: Seminis Vegetable SeedsAsgrow. Parentage: open pollinated. Characteristics: large plant with long pods; medium dark pod color; reliable set under heat; pods are large sieve and are 5.4 inches long; maturity is 65 days, or 1203 heat units at Twin Falls, Idaho. Resistance: bean common mosaic virus (BCMV); intermediate to halo blight. Similar: Hialeah, Bronco. Adaptation: NAFTA, fresh market. PVP application \#200200073. 2002.

Romano Gold (EX 08190506) - Vendor: Seminis Vegetable Seeds-Asgrow. Parentage: open pollinated. Characteristics: Wax Romano type with an excellent, uniform, golden pod color; color contrast with green pods is excellent; blanched $11.7 \mathrm{~cm}$ long pods are highly flavorful. Resistance: bean common mosaic virus (I gene); intermediate to rust and white mold. Adaptation: U.S. 2002.

Sahara (HMX 1945) - Breeder: Steve Magnuson. Vendor: Harris Moran. Parentage: open pollinated. Characteristics: green bean type; 58 days to maturity; upright plant habit; high pod set; sieve size 3-4; pods are medium dark green and 5.5 inches long. Resistance: bacterial brown spot. Adaptation: home garden, U.S. 2003.

Sea Biscuit (XP 15330724) - Breeder and vendor: Seminis Vegetable Seeds. Parentage: open pollinated. Characteristics: low fiber, fresh market type; 51 to 52 day maturity; dark green pods $1 \mathrm{~cm}$ 
diameter and $13 \mathrm{~cm}$ long; determinate upright plant forms medium height bush. Resistance: bean common mosaic virus (I gene), bacterial brown spot. Similar: Shade, Dusky, Festina. Adaptation: NAFTA, southeast U.S. 2005.

Secretariat (XP 08120691) - Breeder and vendor: Seminis Vegetable Seeds. Parentage: inbred line. Characteristics: medium green round pods with height to thickness ratio of 1.07; pods are slightly longer than Bronco; medium to large determinate bush plant type; good yield. Resistance: Bean common mosaic virus (I gene). Similar: Shade, Charon. Adaptation: NAFTA, Northeast and Southeast. 2005.

Slenderpack (XP 08780412)—Vendor: Seminis Vegetable Seeds-Asgrow. Parentage: open pollinated. Characteristics: widely adapted, dual purpose bean for intermediate sieve processing and fresh markets; distribution of 38\% 1-3, 53\% 4, and 9\% 5-6 sieve sizes (6.4\% seed); pod length of $132 \mathrm{~mm}$. Resistance: anthracnose (races delta, gamma), bean common mosaic virus (I gene). Similar: Celtic, Medinah, Minuette. Adaptation: NAFTA areas. 2002.

Spartacus (XP 08110633)—Breeder and vendor: Seminis. Parentage: open pollinated. Characteristics: processor, determinate bush type; high yielding with good pod quality and dark green color; pod length is 5.5 inches long with moderate to slow seed development; plant is upright with a medium size bush that holds the pods well off the ground. Resistance: bean common mosaic ("I" gene), intermediate to bacterial brown spot. Similar: True Blue, Summit. Adaptation: NAFTA - Northeast and Midwest processors. 2005.

Thoroughbred (XP 08100518) - Breeder and vendor: Seminis Vegetable Seeds-Asgrow. Parentage: open pollinated. Characteristics: medium green bush type garden bean; white seeds; higher yielding than Opus in South Florida; pods smoother and darker green than Opus; not as dark as Bronco; pods $142 \mathrm{~mm}$ long; sieve size distribution similar to Opus; 53 day maturity (like Opus, Bronco). Resistance: Bean Common Mosaic virus (I gene). Similar: Leon, Opus, Bronco. Adaptation: southeast U.S., Florida. PVP Application \#200300069. 2003.

Ulysses (XP 08120670) - Breeder and vendor: Seminis. Parentage: open pollinated. Characteristics: processor, determinate bush type; high yielding with good pod quality and deep green color; pod length is 5.5 inches long with moderate to slow seed development; plant is upright with a medium size bush that holds the pods well off the ground. Resistance: Bean common mosaic virus ("I" gene), intermediate to bacterial brown spot. Similar: True Blue, Summit. Adaptation: NAFTA-Northeast and Midwest processors. 2005.

Valentino (XP 15321397) - Breeder and vendor: Seminis. Parentage: open pollinated. Characteristics: fresh market type with medium dark green pods; pod length is $12-15 \mathrm{~cm}$ with a round cross section; the pods are straight and well positioned in the plant, not touching the soil; pod setting is well concentrated; suitable for mechanical harvest. Similar: Bronco, Festina. Adaptation: NAFTANortheast U.S. and Southeast U.S. 2005.

Veronica (XP 15330723) - Breeder and vendor: Seminis. Parentage: open pollinated. Characteristics: low fiber fresh market type, early mid season maturity (51-52 days), dark green pods of $1 \mathrm{~cm}$ diameter (4 sieve) and $13 \mathrm{~cm}$ (5.1 inch) in length; determinate, upright plant forms medium-height bush. Similar: Shade, Cahron, Hialeah. Adaptation: NAFTA-Fresh Market. 2005.

\section{BEET}

Etna (PS 2189) - Breeder and vendor: Seminis Vegetable Seeds. Parentage: hybrid. Characteristics: dull, glossy green leaves; 14 to 16 inches tall; very strong leaf attachment for easy pulling; nice blood red interior color; excellent round shape for small beet processors; early maturity. Similar: Little Ball, Red Ace. Adaptation: NAFTA. 2005.

\section{BROCCOLI}

BC602-Breeder and vendor: Daenhfeldt. Characteristics: slightly earlier than BC600; excellent quality in a high-domed head; well suited for crown cuts; tight head with good color and minimal hollow core in the heat. 2005.

Concord-Breeder and vendor: Syngenta Seeds, Inc./Rogers Brand. Characteristics: newly released broccoli variety; shown good adaptation to cooler production seasons and has demonstrated excellent adaptability in trials and commercial plantings in the spring and fall harvest periods in the Salinas Valley; has also performed well in the desert Southwest. 2005.

Demoledor (254302) - Breeder and vendor: Seminis. Parentage: F1 hybrid. Characteristics: hybrid broccoli for cool season segment; plant type is open, erect, so easy to work and harvest; good uniformity; leaves narrow at the petioles so the product is easy to clean at harvest; heads are deep, domed, and firm; can be used for both fresh market and processing. Similar: Marathon, Monaco. Adaptation: NAFTA-Mexico. 2005.

Denali (BOS 1030)-Breeder and vendor: Orsetti Seed Co. Characteristics: tall frame; firm, semi-raised head; medium fine beads; clean stalk; 80-85 days to maturity. Adaptation: U.S. 2002.

FM 198 (FMX 198) - Breeder and vendor: Ferry Morse. Parentage: F1 hybrid. Characteristics: early maturing, widely adapted, performs best in the spring and fall with tolerance to both heat and cold; beads are small to medium size, tight and uniform; head shape is domed to slightly flat; good head weight. Adaptation: U.S. 2002.

Grandisimo (HNX 11721105) - Breeder and vendor: Seminis Vegetable Seeds. Parentage: F1 hybrid. Characteristics: maturity is 80-83 days, deep green and high dome head with very fine bead; no side stems. Similar: Marathon. Adaptation: NAFTA-Mexico. 2004. Green Magic - Breeder and vendor: Sakata Seed America, Inc. Characteristics: summer-type broccoli; good uniformity and holding ability; mid-early maturing; semi-dome tight head, with mediumsmall bead size and good plant habit. Adaptation: wide adaptability 2005.

Gypsy_-Breeder and vendor: Stokes Seeds, Inc. Characteristics: smooth domed heads; good holding ability in warm weather; has medium-sized beads on 6-inch heads; plants are uniform; can be used for singles, bunching, or crown cuts. Resistance: tolerant to downy mildew. 2005.

Olympia-Breeder and vendor: Sakata Seed America, Inc. Characteristics: good uniformity; yields a dome-shaped head. Similar: Marathon. Adaptation: ideal for crown, bunch, or processing markets. 2005.

Revolution (PS 0511095) - Breeder and vendor: Seminis Vegetable Seeds. Parentage: F1 hybrid. Characteristics: fast maturing; for the main season in Yuma, Arizona and cool and transition season of the Salinas Valley, California; head size is large; plant produces smooth dome shaped heads with fine bead size; stalk cleans easily; compact plant is well suited for high densities. Similar: Marathon. Adaptation: NAFTA-Arizona, California. 2004.

Rookie (BC600) - Breeder and vendor: Daenhfeldt. Characteristics: main season broccoli; high-domed head perfect for crown cuts; tolerant to heat; does not hollow in mid-summer; excellent quality, high dome, no hollow core. 2005.

Tlaloc (PS 261295) - Breeder and vendor: Seminis Vegetable Seeds. Parentage: F1 hybrid. Characteristics: Tlaloc is the God of Rain in Mexican culture; warm season type; heavy head; fine bead; thick petiole for heavy florets; strong, medium plant frame with no side shoots and very thick stem. Similar: Patriot, Patron. Adaptation: NAFTA, Mexico. 2004.

Tradition (PS 511018) - Breeder and vendor: Seminis Vegetable Seeds-Petoseed. Parentage: F1 hybrid. Characteristics: main season in warm/hot conditions, high dome, medium bead, refined stalk, excellent uniformity, improved heat tolerance as compared to competing cultivars for the same harvest slot, resulting in 3-4 days earlier harvest. Similar: Patriot, Patron. Adaptation: California, Mexico. 2002.

Warrior (SSC 14181) - Breeder and vendor: Shamrock Seeds. Parentage: F1 hybrid. Characteristics: for production through winter and spring, but also for year round production in regions with cool summers; produces tall, blue-green plants with an upright structure; makes large heads (6-inch diameter) with a relatively smooth, domed 
shape and small beads; its short floret petioles ensure a compact head structure and its thick, clean stalk provides weight. Resistance: moderate tolerance to mildew. Similar: Marathon, Legacy, Heritage. Adaptation: U.S. broccoli production areas in the cool season. 2004.

\section{CABBAGE}

Constellation (RS 05843307)—Breeder and vendor: Seminis. Parentage: F1 hybrid. Characteristics: late (118 days after transplanting) maturity, storage cabbage; large frame, dense head, good wrapper leaf protection; rounder head than many other storage cultivars, which is an advantage for packing and marketing; head color is blue-green; holds up well to decay in storage, requiring a minimal amount of trimming and retains its blue-green color well in storage. Similar: Amtrak, Bingo. Adaptation: NAFTA-Northeast and Canada. 2005.

Deuce (HMX 0222)-Breeder: S.A. Clause. Vendor: Harris Moran. Parentage: F1 hybrid. Characteristics: large head cabbage, with small core and white interior; for processing and kraut. Resistance: Fusarium yellows. Adaptation: northeastern U.S. 2003.

Early Thunder (HMX 0228)-Breeder and vendor: Harris Moran. Parentage: F1 hybrid. Characteristics: early maturing; round uniform heads; excellent field holding ability; slow bolting and mild texture and taste. Resistance: Fusarium yellows (race 1); tolerance to black rot. Adaptation: U.S. fresh market. 2002.

Encore (HMX 0224)-Breeder: Clause Tezier. Vendor: Harris Moran. Parentage: F1 hybrid. Characteristics: fresh market and processing kraut type; green leaves; large, round, flat, dense head; good field holding ability. Adaptation: U.S. 2003.

Polo (XPH 5786) - Breeder and vendor: Seminis Vegetable Seeds-Asgrow. Parentage: F1 hybrid. Characteristics: medium-late hybrid, matures in 80 to 85 days, tropical type, plants are semi flat and blue-green in color with good canopy for head protection. Similar: Green Coronet. Adaptation: Brazil. 2002.

Ruby Dynasty (EX 5219037) — Breeder and vendor: Seminis Vegetable Seeds-Asgrow. Parentage: F1 hybrid. Characteristics: early maturing red CMS type; 7 to 10 days earlier than Red Dynasty; round heads with good wrapper protection; vigorous and uniform; for fresh market. Similar: Red Rookie. Adaptation: NAFTA — southeast U.S. 2003.

Ruby King - Breeder and vendor: American Takii. Characteristics: early maturing red cabbage with excellent uniformity, high yield potential, and good field holding capability; heads are solid and round-shaped with bright purplish-red color; vigorous grower with excellent wrapped leaves. 2002.

Sagittarius (177868)—Vendor: Seminis Vegetable SeedsAsgrow. Parentage: F1 hybrid. Characteristics: early CMS type intended for fresh market; matures in 95 days in the summer and 105 days in the late spring in Brazil; good holding ability has been noted. Resistance: intermediate to Fusarium yellows. Similar: Shinsei. Adaptation: Brazil. 2002.Savoy Blue (HMX 0220)—Breeder and vendor: Harris Moran. Parentage: F1 hybrid. Characteristics: midearly maturity; savoy type; dark green, round heads; refined interior, tolerant to warm temperatures. Adaptation: U.S. 2002.

Spring Dynasty (XP 5210087) - Breeder and vendor: Seminis Vegetable Seeds-Asgrow. Parentage: F1 hybrid. Characteristics: hybrid with excellent yield potential; ability to make size consistently; holds well with good interior quality; early to mid-season maturity; performs well in Midwest and California; possible use for fresh processing industry. Resistance: Fusarium yellows (race 1) intermediate to black rot. Similar: Little Goblin. Adaptation: NAFTA. 2003.

\section{CABBAGE-CHINESE}

Ohken 75-Breeder: Kyowas Seed. Vendor: Siegers Seed Co. Characteristics: club root tolerant Chinese cabbage; 75-day variety features good uniformity; barrel shaped. Resistance: tolerant to bolting, tip burn, and downy mildew. 1998.

\section{CARROT}

Chantenay \#1 (PS 2590)—Vendor: Seminis Vegetable SeedsPetoseed. Parentage: F1 hybrid. Characteristics: 13-16 cm root length with 4-6 cm root width at crown, tapering to a $1-\mathrm{cm}$ blunt root tip; crisp, juicy texture, medium orange color with uniform color from exterior to interior, medium size core. Resistance: intermediate to Alternaria leaf blight. Adaptation: Chantenay areas. 2002.

Copperhead (SCR 9840) - Breeder and vendor: Sakata Seed America, Inc. Characteristics: variety for any cut and peel growing area; offers good yields of medium tall (10 and 11 inches long); slightly tapered roots with a semi-blunt tip; vigorous tops; great root length and color. 2005.

Cosmic Purple - Breeder and vendor: Johnny's Selected Seeds. Characteristics: eye-catching, 6 to 7 inch deep, purple-skinned carrot with a sweet and spicy flavor; interior color ranges from solid orange to orange with a yellow core; matures in 70 days. 2005.

Dyna Bites (HMX 8913) - Breeder and vendor: Harris Moran. Characteristics: new Imperator carrot for Cut \& Peel and Slicer markets; mid-season, medium dark orange carrot with excellent flavor and texture quality; 10-12 inch tube-shaped carrot features uniform interiors (coreless); wide adaptability to many products. 2005.

Envy (PX 07132127) - Breeder and vendor: Seminis Vegetable Seeds-Petoseed. Parentage: F1 hybrid. Characteristics: early to midseason maturity; early sizing; cylindrical shape with blunt tip; not brittle; good tops for better and easier harvest; 12-inch length, 1.5- to 1.75-inch diameter (depending on spacing); keeps its uniformity on mineral and muck soil. Similar: Apache. Adaptation: NAFTA, northeast U.S. and Canada. 2004.

FM 291 (FMX 291) - Breeder: Court Nichols. Vendor: Harris Moran. Parentage: F1 hybrid. Characteristics: Chantenay type for processing, dicing; length is slightly longer than Royal Chantenay; complements Mark II. Adaptation: U.S. 2002.

Idaho - Breeder and vendor: Bejo Seeds. Parentage: hybrid. Characteristics: heavy-shouldered Imperator with a slight taper; very sweet; great flavor; suited for cellopak, jumbos, juice or slicing; mid-season carrot with strong foliage attachment. 1998.

Invicta (PS 715004) - Breeder and vendor: Seminis Vegetable Seeds. Parentage: F1 hybrid. Characteristics: hybrid fresh market Kuroda type with Nantes shape; length is $15-17 \mathrm{~cm}$ with $2-\mathrm{cm}$ diameter at the crown; slight taper to a $1.5-\mathrm{cm}$ blunt root tip; color is dark orange with uniform color from exterior to interior; medium size core with slight whitish halo around circumference of the core; exterior surface is very smooth; texture is lightly sweet and crisp; excellent eating quality; high uniformity and quality as compared to standard open pollinated cultivars; slower bolting (moderate bolting tolerance) than standard open pollinated cultivars; strong, but medium sized top. Similar: Concerto, Nantes. Adaptation: NAFTA-Mexico. 2004.

Juliana (HX 10206004) - Breeder and vendor: Seminis Vegetable Seeds. Parentage: F1 hybrid. Characteristics: summer type with improved bolting tolerance; cylindrical root shape, earlier maturing than the open pollinated cultivar currently leading the market. Similar: Conquista. Adaptation: NAFTA and Brazil. 2004.

Magnum (HMX 1336) - Breeder: Clause Seed Co. Vendor: Harris Moran. Parentage: F1 hybrid. Characteristics: processing type to be used for slicing; uniform in shape; interior color is acceptable in the market with a very good blunt tip, good length and good yield. Resistance: moderate to Alternaria. Adaptation: jumbo fresh market and storage areas of Canada, and fresh market of Mexico (also Mid West and Texas). 2002.

Maverick-Breeder and vendor: Nunhems. Characteristics: early-maturing; produces good yields of uniform roots that are smooth, have excellent interior color, and good taste. Resistance: excellent tolerance to foliar diseases such as Alternaria. 2005.

Natasha (XP 8415) - Breeder and vendor: Seminis Vegetable Seeds-Asgrow. Parentage: open pollinated. Characteristics: Nantes root type, excellent tops with good internal and external color, slightly pointed shape, good tolerance to bolting, root length $15-18 \mathrm{~cm}$, 
has a thick orange neck, strong leaves, conic shape (visible characteristic of a Flakee type); yield same as Supreme; very uniform shape. Similar: Supreme. Adaptation: NAFTA, Argentina. 2003.

Propeel (PS 07101435) - Breeder and vendor: Seminis. Parentage: Hybrid. Characteristics: cut and peel type carrot, 12-14 inches long; shoulder is $3 / 4$ inches in diameter; $1 / 2$ inch in diameter; slightly blunt tip; good uniform orange color; good for mechanical harvest; good flavor; for short cuts. Similar: Sugarsnaks; Sweetbites. Resistance: none. Adaptation: United States. 2005.

Six Shooter (HMX 6319) - Breeder: Mark Mason. Vendor: Harris Moran. Parentage: F1 hybrid. Characteristics: early maturing Imperator type carrot for cello/jumbo markets with improved color and length; bolt tolerant with good field holding ability. Adaptation: U.S. 2002.

Topcut 93-Breeder and vendor: Sunseeds. Characteristics: long slender, cut-and peel type; roots 10 to 11 inches under high populations; holds the preferred diameter range at maturity; roots have good quality, color, and uniformity. Adaptation: wide. 2002.

Veronesa (RS 2696) - Vendor: Seminis Vegetable Seeds-Royal Sluis. Parentage: F1 hybrid. Characteristics: long Flakee/Kuroda type with blunt tip; good bolting tolerance; very uniform root; for the summer season; very good color and root quality. Similar: Brasilia. Adaptation: Colombia, Brazil. 2002.

\section{CAULIFLOWER}

Absolute (HMX 0226) - Breeder: Clause/Tezier. Vendor: Harris Moran. Parentage: F1 hybrid. Characteristics: main season, fresh market type with medium plant size, excellent curd protection, dense and bright white head color; wide adaptability with very uniform maturity. Adaptation: U.S. 2002.

Alaska (HMX 0227)—Breeder: Clause/Tezier. Vendor: Harris Moran. Parentage: F1 hybrid. Characteristics: for spring harvest in coastal regions and warm wet season in Mexico; medium large plant type providing very good head protection; heads are dense, domed and white. Adaptation: fresh market or processing, U.S. 2002.

Attribute (HMX 0242)-Breeder: Clause/Tezier. Vendor: Harris Moran. Parentage: F1 hybrid. Characteristics: fresh market production in the eastern U.S.; also for baby production in the western U.S.; good quality dome with exceptional white color and good yields. Adaptation: fresh market, U.S. 2003.

CA712 - Breeder and vendor: Daenhfeldt. Characteristics: combines brilliant white colored curds with a high tight dome shape; has an excellent wrapper and firm curd; well-suited for processing; can be used in both spring/summer crops at 65 to 75 days and fall crops at 80 to 90 days; offers earliness and quality. 2005.

Casper RZ - Breeder and vendor: Rijk Zwaan. Characteristics: heat tolerant; very dense white and smooth head, performs especially well under warm and dry conditions. 2002.

Cheddar (PX 66196) - Breeder and vendor: Seminis Vegetable Seeds. Parentage: F1 hybrid. Characteristics: medium weight curds, firmness; medium orange with elevated beta carotene level. Adaptation: NAFTA - Northeast and Southwest Coastal U.S. 2004.

Cielo Blanco (PS 514415) - Breeder and vendor: Seminis Vegetable Seeds. Parentage: F1 hybrid. Characteristics: vigorous, self blanching type for winter harvest in California and Arizona; produces heavy, smooth white curds that are well protected; for fresh market and processing. Similar: White Magic, Incline, Shasta. Adaptation: NAFTA — Southwest Coastal U.S. and Mexico. 2004.

Graffiti-Breeder and vendor: Daenhfeldt. Characteristics: unlike any other cauliflower on the market; unique purple head, gets its iridescent color from anthocyanin, one of the leading antioxidants in the battle against cancer; combination of color and nutritional values offer a product that is truly different, this medium-early cultivar features a large frame with good curd protection; suitable for fresh market and processing. Resistance: tolerance to downy mildew. Adaptation: suitable for a broad range of climatic conditions. 2005.

Juneau (PS 05104612) - Breeder and vendor: Seminis. Parentage: Hybrid. Characteristics: vigorous plant with medium large frame and good self-wrapping capabilities; matures in 85-100 days depending on season; very adaptable; produces smooth domes with excellent color, weight and quality. Similar: Symphony and Shasta. Resistance: None. Adaptation: NAFTA- Southwest U.S. 2005.

Summer Streak (NA 11) —Vendor: Seminis Vegetable SeedsAsgrow. Parentage: F1 hybrid. Characteristics: early season, firm and compact heads, very white color, can be used for processor/freezer and fresh market; unique appearance. Adaptation: Brazil. 2002.

Whistler (PX 514481)—Vendor: Seminis Vegetable Seeds. Parentage: F1 hybrid. Characteristics: main season type; large plant with good wrapping habit; smooth dome head with excellent white color and weight. Similar: Apex, Attribute, Freemont, Freedom. Adaptation: NAFTA—northeast U.S., main season. 2004.

\section{CELERY}

Calypso - Breeder and vendor: Bejo Seeds. Parentage: open pollinated. Characteristics: smooth, compact plant, intermediate Fusarium and bolt tolerance. Adaptation: Coastal California. 2004.

Command (PYC 2531) - Breeder and Vendor: Pybas Vegetable Seed Co. Parentage: Matador; open pollinated. Characteristics: Similar to Matador though somewhat shorter with more smooth dark green petioles; slower to bolt than Matador. Resistance: Fusarium yellows. Adaptation: California coastal valleys. 2004.

Discovery F1 (PCH6848) - Breeder and Vendor: Pybas Vegetable Seed Co. Characteristics: F1 hybrid similar to Command with smooth medium green petioles. Resistance: Fusarium yellows. Adaptation: California coastal valleys. 2006.

Dutchess (PYC 9112) - Breeder and Vendor: Pybas Vegetable Seed Co. Parentage: open pollinated. Characteristics: improved XP 85 type, best suited for celery processing in the Midwestern United States. Resistance: Fusarium yellows. Adaptation: Michigan, Wisconsin. 2002.

Mission (PYC 2510) - Breeder and Vendor: Pybas Vegetable Seed Co. Parentage: open pollinated. Characteristics: like Napoleon, but slightly taller, with more dark green smooth petioles. Tolerant to bolting. Resistance: Fusarium yellows. Adaptation: California coastal valleys. 2004.

Stix (PYC 6651) - Breeder and Vendor: Pybas Vegetable Seed Co. Parentage: open pollinated. Characteristics: exceptionally tall dark green celery with medium-smooth, slender petioles; especially suited to processing into shorter sticks. Resistance: Fusarium yellows. Adaptation: California coastal valleys. 2006.

Triple Eight (PS 06510888) - Breeder and vendor: Seminis Vegetable Seeds. Parentage: open pollinated. Characteristics: Tall Utah type; medium green color with slightly wider petioles; uniform height; tight shingling of inner stalks and cover; planted in spring and summer in Santa Maria and Salinas Valley, California; winter transplants in Ventura County, California. Similar: Sonora, Conquistador. Adaptation: Salinas Valley, Santa Maria and Ventura County, California. 2004.

\section{COLLARD}

Hi-Crop-Breeder and vendor: American Takii, Inc. Parentage: hybrid. Characteristics: versatile and vigorous; tolerant to heat and cold; uniform plants that produce tender dark-green, semi-savoyed leaves. 2005.

\section{CUCUMBER}

\author{
Todd C. Wehner \\ Department of Horticultural Science \\ North Carolina State University \\ Raleigh, NC 27695-7609
}

22-32 RZ—Vendor: Rijk Zwaan. Parentage: F1 hybrid. Characteristics: 16-18 cm fruit length; dark green fruit color; slightly ribbed; strong vigor; broad growing spectrum; self-pruning laterals; 
powdery mildew resistant and highly tolerant to CMV, CVYV, ZMV and Papaya ring spot virus; good shelf life. Adaptation: U.S. 2002.

22-35 RZ - Vendor: Rijk Zwaan. Parentage: F1 hybrid. Characteristics: 16-18 cm fruit length; dark green fruit color; slightly ribbed; medium vigor; performs well in warmer conditions; powdery mildew resistant and tolerant to CMV, CVYV, ZYMV, and PRSV. Adaptation: U.S. 2003.

22-64 RZ — Vendor: Rijk Zwaan. Parentage: F1 hybrid. Characteristics: 18-20 cm fruit length; dark green fruit color; slightly ribbed; very strong vigor; suitable for cold and stress conditions; tolerant to powdery mildew. Adaptation: U.S. 2003.

Accordia RZ - Vendor: Rijk Zwaan. Parentage: F1 hybrid. Characteristics: very early; easy to pick; good regeneration; high yields; smooth fruits; L/D ratio 3:1; powdery mildew resistant. Adaptation: U.S. 2003.

ACX 5001 - Vendor: Abbott \& Cobb. Parentage: hybrid. Characteristics: 60 days to maturity; cylindrical fruit; 8-8.5 inches long; medium plant; long picking season; multiple disease resistance and tolerances. Adaptation: U.S. 2005.

Adrian RZ - Vendor: Rijk Zwaan. Parentage: F1 hybrid. Characteristics: $18-20 \mathrm{~cm}$ fruit length; dark green fruit color; medium vigor; spined fruit; parthenocarpic; open plant habit; tolerant to CMV and PM; low labor input required. Adaptation: U.S. 2003.

Ajax - Vendor: Sunseeds. Characteristics: 53 days to maturity; blocky fruit shape; long vine; medium fruit color. Adaptation: U.S. 2005.

Alanis RZ_Vendor: Rijk Zwaan. Parentage: F1 hybrid. Characteristics: 19-22 cm fruit length; dark green fruit color; strong vigor; parthenocarpic slicer; good shelf life. Adaptation: U.S. 2003.

Alibi-Breeder and vendor: Johnny's Selected Seeds. Characteristics: fresh flavor; good brining characteristics; suitable for picking or fresh eating; dark-green, uniform fruit; grows on vines that are somewhat shorter than typical vines; predominantly female flowering plant with high yield potential. 2005.

Aramon RZ-Vendor: Rijk Zwaan. Parentage: F1 hybrid. Characteristics: $30-35 \mathrm{~cm}$ fruit length; dark green fruit color; medium vigor; powdery mildew resistant; strong against burnt heads; good for hot summer conditions. Adaptation: U.S. 2003.

Autograph - Vendor: SeedWay. Parentage: hybrid. Characteristics: 58 days to maturity; 8 inch $\times 2.5$ inch fruit size; vigorous pollinator; high yield. Adaptation: U.S. 2002.

Aviance RZ-Vendor: Rijk Zwaan. Parentage: F1 hybrid. Characteristics: $30-35 \mathrm{~cm}$ fruit length; dark green fruit color; strong vigor; early; high production; tolerant to powdery mildew; good shelf life. Adaptation: U.S. 2002.

Azor RZ-Vendor: Rijk Zwaan. Parentage: F1 hybrid. Characteristics: $32-38 \mathrm{~cm}$ fruit length; medium green fruit color; medium vigor; slender fruit shape; dark green and shiny fruit with ribs and short handles; open plant habit; early maturity; suitable for short cultures and recommended for autumn and spring cultivation. Adaptation: U.S. 2002.

Bahher RZ_-Vendor: Rijk Zwaan. Parentage: F1 hybrid. Characteristics: $13-15 \mathrm{~cm}$ fruit length; medium green fruit color; strong vigor; smooth skintolerant to cucumber vein yellowing virus; zucchini yellow mosaic virus; and papaya ring spot virus; very strong against downy mildew. Adaptation: U.S. 2003.

Ballerina (SX2686PU) - Vendor: Sunseeds. Parentage: parthenocarpic. Characteristics: 53 days to maturity; slight taper to fruit; long vine; dark fruit color. Adaptation: U.S. 2005.

Bodega RZ - Vendor: Rijk Zwaan. Parentage: F1 hybrid. Characteristics: $32-38 \mathrm{~cm}$ fruit length; dark green fruit color; strong vigor; medium earliness; open plant habit; good tolerance to powdery mildew; suitable for early planting; very productive. Adaptation: U.S. 2003.

Boothby's Blonde - Vendor: Seed Savers Exchange. Characteristics: oval fruit 6-8 inches long; creamy-yellow warty fruit with black spines; excellent flavor; 55-60 days to maturity. Adaptation: U.S. 2003.

Bushy-Vendor: Seed Savers Exchange. Characteristics: compact plants with 3-5 ft vines; good production; 46-49 days to maturity. Adaptation: U.S. 1992.
Cadiz RZ—Vendor: Rijk Zwaan. Parentage: F1 hybrid. Characteristics: $32-38 \mathrm{~cm}$ fruit length; medium green fruit color; strong vigor; powdery mildew resistant; good regrowth; open plant habit; strong fruit set; strong against skin cracking; rounded base fruit. Adaptation: U.S. 2003.

Cobra-Breeder and vendor: Rispens Seeds, Inc. Characteristics: beautiful dark green color; fantastic yields; excellent disease package; great quality. Adaptation: U.S. 2005.

Competitor-Vendor: SeedWay. Parentage: hybrid. Characteristics: 58 days to maturity; 8 -inch long fruit; moderate resistance to scab, cucumber mosaic virus, powdery mildew, downy mildew, anthracnose, and angular leaf spot. Adaptation: U.S. 2005.

Componist RZ-Vendor: Rijk Zwaan. Parentage: F1 hybrid. Characteristics: parthenocarpic; spined; manual harvesting; high yield potential; L/D ratio is $3.1: 1$; resistant to powdery mildew; tolerant to CMV; resistant to scab. Adaptation: U.S. 2003.

Condesa RZ - Vendor: Rijk Zwaan. Parentage: F1 hybrid. Characteristics: 15-18 cm fruit length; medium green fruit color; slightly ribbed; strong vigor; excellent shelf life; resistant to powdery mildew and scab. Adaptation: U.S. 2003.

Cool Breeze-Vendor: Seminis. Parentage: parthenocarpic. Characteristics: 45 days to maturity; fine spines and thin skin; high productivity. Adaptation: U.S. 1999.

Crescendo RZ-Vendor: Rijk Zwaan. Parentage: F1 hybrid. Characteristics: good regeneration; uniform, dark green fruits; fruit L/D ratio is 3:1; powdery mildew tolerant. Adaptation: U.S. 2003.

Cumlaude RZ-Vendor: Rijk Zwaan. Parentage: F1 hybrid. Characteristics: $30-35 \mathrm{~cm}$ fruit length; dark green fruit color; medium vigor; powdery mildew resistant; open plant habit; strong against burnt heads and mycosphaerella; good stamina. Adaptation: U.S. 2003.

Deltastar RZ-Vendor: Rijk Zwaan. Parentage: F1 hybrid. Characteristics: 16-18 cm fruit length; dark green fruit; slightly ribbed; strong vigor; excellent shelf life; good flavor; highly tolerant to cucumber mosaic virus, cucumber vein yellow virus, and powdery mildew. Adaptation: U.S. 2003.

Eclipse - Vendor: Harris Moran. Characteristics: blocky to slight tapered fruit shape; 2.9-3.1 LD ratio; mid maturity; medium to dark green fruit color; resistant to SCAB, ALS, ANTH; fruit sets well for machine harvest. Adaptation: U.S. 2005.

Expedition (SVR 04506116) - Breeder and vendor: Seminis Vegetable Seeds. Parentage: F1 hybrid. Characteristics: gynoecious pickle, dark green blocky fruit with 3.0 to $3.06 \mathrm{~L} / \mathrm{D}$; high yield; excellent fruit color and shape; machine pick; 1 to 2 days earlier than Vlaspik. Resistance: angular leaf spot, cucumber mosaic virus, scab; intermediate to anthracnose, powdery mildew, downy mildew. Similar: Lafayette, Sassy, Discover. Adaptation: NAFTA—southeast U.S. 2005.

Feisty (HMX 9464) - Breeder: Gary Taurick. Vendor: Harris Moran. Parentage: F1 hybrid. Characteristics: pickling type; dark green indeterminate vines; fruit with small seedcell; $3.2 \mathrm{~L} / \mathrm{D}$ ratio. Adaptation: U.S. 2003.

Gardon RZ-Vendor: Rijk Zwaan. Parentage: F1 hybrid. Characteristics: $30-35 \mathrm{~cm}$ fruit length; medium green fruit color; medium vigor; CMV and powdery mildew tolerant; high yield. Adaptation: U.S. 2003

Gianco RZ - Vendor: Rijk Zwaan. Parentage: F1 hybrid. Characteristics: 17-19 cm fruit length; dark green fruit color; medium vigor; slightly ribbed; strong in stress conditions such as heat; highly tolerant to CMV, CVYV, and ZYMV; good shelf life. Adaptation: U.S. 2003.

Harmonie RZ_-Vendor: Rijk Zwaan. Parentage: F1 hybrid. Characteristics: very early; high yield; vigorous; firm straight fruits; small diameter; medium green; resistant to powdery mildew; tolerant to CMV; resistant to scab. Adaptation: U.S. 2003.

HMX 8461 - Vendor: Harris Moran. Characteristics: mid maturity; medium green fruit color; white spine; 2.9-3.1 LD ratio; medium fruit set concentration; resistant to SCAB; very blocky fruit; highly rated in brinestock tests. Adaptation: U.S. 2002.

HMX 9466 - Vendor: Harris Moran. Characteristics: mid maturity; medium green fruit color; white spine; 2.8-3.0 LD ratio; resistant 
to SCAB, ALS, ANTH, CMV; uniform size; good for hand harvest. Adaptation: U.S. 2002.

Homemade Pickles-Vendor: Seminis. Parentage: open pollinated. Characteristics: 56 days to maturity; medium green fruit with small white spines; good for home gardens and home pickling; vigorous plants. Adaptation: U.S. 2002.

Impact-Breeder and vendor: Siegers Seed Company. Characteristics: early-maturing slicer with high yields of super-select, darkgreen fruits. Resistance: anthracnose, angular leaf spot, powdery mildew, scab, watermelon mosaic virus, zucchini yellow mosaic virus. Adaptation: U.S. 2005.

Ivory Queen-Breeder and vendor: Burpee. Characteristics: fruit have white skin. 2005.

Journey (XP 04504229) — Breeder and vendor: Seminis Vegetable Seeds-Asgrow. Parentage: F1 hybrid. Characteristics: dark green blocky fruit with a 3.00-3.06 L/D ratio; heavy yield, excellent fruit color and shape for machine pick for processors; darker fruit color and better or equal yield to Vlaspik, 1-2 days earlier than Vlaspik. Resistance: downy mildew, anthracnose, scab, angular leafspot, cucumber mosaic. Similar: Lafayette, Vlaspik, HMX 9465. Adaptation: NAFTA. 2003.

Lynx - Breeder and vendor: Nunhems. Characteristics: excellent length and color; main season maturity. Resistance: resistant to many viruses. 2005.

Midas (SSC 1364) - Breeder: Magnum Seeds. Vendor: Shamrock Seed Co. Parentage: F1 hybrid. Characteristics: a multi-virus resistant, monoecious slicing type; very vigorous plant with abundant, dark green foliage; produces a uniform crop of dark green, firm fruit; high yields of fruit measuring $8-9 \times 2$ inches $(\mathrm{L} \times \mathrm{W})$; maintains a smooth, cylindrical shape under hot growing conditions. Resistance: cucumber mosaic virus, zucchini yellow mosaic virus, papaya ringspot virus, watermelon mosaic virus, angular leafspot, anthracnose, scab, powdery mildew and moderate resistance to downy mildew. Similar: Conquistador. Adaptation: U.S. cucumber growing regions. 2003.

Miniature White-Vendor: Seed Savers Exchange. Characteristics: miniature; yellow-white fruit; no need to peel; very productive; vines up to $3 \mathrm{ft}$; 50-55 days to maturity. Adaptation: U.S. 2003.

Miranda (LD997552) - Breeder and vendor: Daenhfeldt. Characteristics: new F1 long English-type cucumber for the greenhouse; produces fruits of high quality; excellent dark-green color. Adaptation: winter plantings in Northern climates. 2005.

Moxie (HMX 8460)_-Breeder: Gary Taurick. Vendor: Harris Moran. Parentage: F1 hybrid. Characteristics: pickling type; dark green fruit color with excellent block shape; small seedcell; 3.0 L/D ratio; mid-late maturity; resistant to SCAB. Adaptation: U.S. 2003.

Musica RZ - Vendor: Rijk Zwaan. Parentage: F1 hybrid. Characteristics: very productive; smooth, marbled fruits; fruit L/D ratio is 3:1. Adaptation: U.S. 2003.

NC-Davie $($ NC-54 $\times$ NC-55) - Breeder: T.C. Wehner. Vendor: North Carolina State University, Raleigh. Parentage: F1 hybrid of NC-54 (dwarf-determinate, gynoecious) $\times$ NC-55 (tallindeterminate, monoecious) inbreds; S10 inbreds from NCEDP population, cycle 9 . Characteristics: slightly gynoecious pickling hybrid, medium size vines with short hypocotyl, dark green leaves, semi-determinate flowering habit; high yield, early maturity; dark green fruit, L/D 3.0, good processing quality, good keeping ability, bloater resistance. Resistance: anthracnose, powdery mildew, scab. Similar: Raleigh. Adaptation: southern U.S. 2004.

NC-Duplin $(\mathbf{N C - 5 6} \times \mathbf{N C - 5 7 )}$ - Breeder: T.C. Wehner. Vendor: North Carolina State University, Raleigh. Parentage: F1 hybrid of NC-56 (dwarf-determinate, gynoecious) $\times$ NC-57 (tall-indeterminate, monoecious) inbreds; S10 inbreds from NCEDP population, cycle 9. Characteristics: slightly gynoecious pickling hybrid, medium size vines with short hypocotyl, dark green leaves, semi-determinate flowering habit; high yield, early maturity; dark green fruit, L/D 3.1, good processing quality, good keeping ability, bloater resistance. Resistance: anthracnose, powdery mildew, scab. Similar: Johnston. Adaptation: southern U.S. 2004.
NC-Stratford $(\mathbf{N C - 5 8} \times \mathbf{N C - 5 9 )}$ - Breeder: T.C. Wehner. Vendor: North Carolina State University, Raleigh. Parentage: F1 hybrid of NC-58 (dwarf-determinate, monoecious) $\times$ NC-59 (dwarf-determinate, monoecious) inbreds; S10 inbreds from NCEDS population, cycle 9. Characteristics: monoecious slicing hybrid, medium dwarf size vines with short hypocotyl, dark green leaves, and dwarf-determinate plant type, slightly longer vines than NC-Sunshine; high yield, early maturity; dark green fruit, $207 \mathrm{~mm}$ (191-246 mm) fruit length, good fresh-market quality, and good keeping ability. Resistance: anthracnose, powdery mildew, scab. Similar: Dasher II. Adaptation: southern U.S. 2004.

NC-Sunshine $($ NC-62 $\times$ NC-63)-Breeder: T.C. Wehner. Vendor: North Carolina State University, Raleigh. Parentage: F1 hybrid of NC-62 (dwarf-determinate, monoecious) $\times$ NC-63 (dwarfdeterminate, monoecious) inbreds; S10 inbreds from NCEDS population, cycle 9. Characteristics: monoecious slicing hybrid with high percentage of pistillate nodes, medium dwarf size vines with short hypocotyl, dark green leaves, and dwarf-determinate plant type, slightly shorter vines than NC-Stratford; high yield, early maturity; very dark green fruit, $202 \mathrm{~mm}(186-218 \mathrm{~mm})$ fruit length, good freshmarket quality, and good keeping ability. Resistance: anthracnose, powdery mildew, scab. Similar: Dasher II. Adaptation: southern U.S. 2004.

Odessa RZ — Vendor: Rijk Zwaan. Parentage: F1 hybrid. Characteristics: $30-35 \mathrm{~cm}$ fruit length; dark green fruit color; medium vigor; good results with glasshouse cultivation; mildew-tolerant; good stamina. Adaptation: U.S. 2003.

Opera RZ —Vendor: Rijk Zwaan. Parentage: F1 hybrid. Characteristics: straight fruits; small, firm, spiny; dark green fruit; medium early and very productive; L/D ratio is $2.9: 1$, tolerant to powdery mildew and CMV; resistant to scab. Adaptation: U.S. 2003.

Orient Express - Vendor: SeedWay. Parentage: hybrid. Characteristics: burpless; 62 days to maturity; 12-inch long fruit; smooth taste. Adaptation: U.S. 2002.

Parade - Vendor: Seed Savers Exchange. Characteristics: heavy set of uniform fruit; 5-inch long fruit; resistant to extreme weather conditions; 50-60 days to maturity. Adaptation: U.S. 2003.

Placido RZ — Vendor: Rijk Zwaan. Parentage: F1 hybrid. Characteristics: smooth parthenocarpic segment; high-yielding; good regeneration; medium green fruits fruit $\mathrm{L} / \mathrm{D}$ ratio $3: 1$; powdery mildew resistant. Adaptation: U.S. 2003.

Powerpack (XP 1904)-Vendor: Seminis Vegetable SeedsAsgrow. Parentage: F1 hybrid. Characteristics: pickling type for hand harvest. Resistance: PRSV, ZYMV, scab, downy mildew; intermediate to anthracnose, powdery mildew, and angular leafspot. Similar: Vlasset, Duke. Adaptation: NAFTA, Brazil, Mexico. 2002.

Prancer-Vendor: Siegers Seed Co. Parentage: hybrid. Characteristics: 58 days to maturity; 8-inch long fruit; tolerant to downy mildew. Adaptation: U.S. 2005.

Radiant RZ - Vendor: Rijk Zwaan. Parentage: F1 hybrid. Characteristics: 16-18 cm fruit length; dark green fruit color; medium vigor; slightly ribbed; very strong against fruit abortion under stress conditions; highly tolerant to cucumber mosaic virus, CVYV and powdery mildew. Adaptation: U.S. 2003.

Rania RZ-Vendor: Rijk Zwaan. Parentage: F1 hybrid. Characteristics: $14-15 \mathrm{~cm}$ fruit length; medium dark green fruit color; medium vigor; slightly ribbed; resistant to powdery mildew and scab. Adaptation: U.S. 2003.

Sassy (HMX 9465) - Breeder: Gary Taurick. Vendor: Harris Moran. Parentage: F1 hybrid. Characteristics: pickling type; dark green indeterminate vines; fruit with small seedcell; $3.3 \mathrm{~L} / \mathrm{D}$ ratio. Adaptation: U.S. 2003.

Sauna (CB882) - Breeder and vendor: Daenhfeldt. Characteristics: new Beit Alpha type for the greenhouse; self-pruning with an open habit; delivers high yields of excellent fruit for spring and summer crops. Resistance: downy mildew, powdery mildew, angular leaf spot. Adaptation: U.S. 2005.

Scotinos RZ-Vendor: Rijk Zwaan. Parentage: F1 hybrid. Characteristics: $32-38 \mathrm{~cm}$ fruit length; dark green fruit color; strong vigor; successful as a winter crop; powdery mildew tolerant; long, slender fruits. Adaptation: U.S. 2003. 
SCU 6601-Vendor: Sakata Seed America, Inc. Parentage: hybrid. Characteristics: mid early maturity; $22-\mathrm{cm}$ fruit; dark green fruit; smooth skin; tolerant to CMV, AN1,3, and powdery mildew; resistant to Scab; good yield. Adaptation: U.S. 2002.

Slice More (SCU 6601)-Breeder and vendor: Sakata Seed America. Parentage: F1 hybrid. Characteristics: mid-early maturity; 8.5-inch-long fruits; predominantly gynoecious slicing type, mediumsize vine, uniform dark green fruit, high yielding. Resistance: scab, downy mildew, powdery mildew; tolerance to CMV, anthracnose races 1, 3. Similar: Dasher II. Adaptation: fresh-market; wide. 2001.

Sonate RZ - Vendor: Rijk Zwaan. Parentage: F1 hybrid. Characteristics: spined fruits; L/D ratio is 3:1; medium green fruit color; good tolerance to downy mildew. Adaptation: U.S. 2003.

Spunky (HMX 0469) — Breeder: Gary Taurick. Vendor: Harris Moran. Parentage: F1 hybrid. Characteristics: pickling type; medium green color with very uniform, straight, blocky fruit; very small seedcell with slow seed development; 3.0 L/D ratio. Adaptation: U.S. 2003.

Talladega (PX 3502179) — Breeder and vendor: Seminis Vegetable Seeds-Petoseed. Parentage: F1 hybrid. Characteristics: early, productive gynoecious American slicing type with uniform dark smooth fruit and very few spines; strong plant; fruit at market stage are $20 \mathrm{~cm} \times 6 \mathrm{~cm}$; adaptable; no blossom end star or ridging. Similar: General Lee, Stonewall. Adaptation: NAFTA, southeast U.S. 2004.

Tiffany-Breeder and vendor: Daehnfeldt/SeedWorks. Characteristics: high-yielding, European greenhouse slicer for planting in heated greenhouses; medium vigor, and dark-green fruit measure 30 to $35 \mathrm{~cm}$ long; suitable for fresh market. Resistance: tolerant to powdery mildew. 2001.

Timor-Vendor: Hazera. Parentage: hybrid. Characteristics: 45 days to maturity; 6-7 inch long fruits; dark green; slightly ribbed and uniform fruit; high yield potential. Adaptation: U.S. 2002.

True Lemon-Vendor: Seed Savers Exchange. Parentage: F1 hybrid. Characteristics: similar in appearance to a lemon; rust and drought resistant; 58-70 days to maturity. Adaptation: U.S. 1894.

Vero (PS 13292) - Breeder and vendor: Seminis Vegetable Seeds-Petoseed. Parentage: F1 hybrid. Characteristics: white spined, indeterminate vine for hand harvest, L/D approximately 3.25 ; very strong vined, dark green fruit, small seedcell. Resistance: anthracnose, downy mildew, scab, papaya ringspot, watermelon mosaic, zucchini yellow mosaic; intermediate to angular leafspot, powdery mildew, cucumber mosaic. Adaptation: California, Midwest and Northeast U.S., Mexico, Brazil. 2002.

Vert de Massy-Vendor: Willhite. Characteristics: 53 days to maturity; good texture; used for pickling; tolerant to scab; black spine. Adaptation: U.S. 2003.

Vertina-Vendor: Sunseeds. Characteristics: 54 days to maturity; blocky fruit shape; long vine; medium fruit color. Adaptation: U.S. 2005.

Virginian RZ-Vendor: Rijk Zwaan. Parentage: F1 hybrid. Characteristics: $32-38 \mathrm{~cm}$ fruit length; medium green fruit; very strong vigor; early maturity; medium jointed and open plant habit. Adaptation: U.S. 2002.

Vlasspear-Vendor: Asgrow. Parentage: hybrid. Characteristics: Medium to large fruit; medium foliage; medium to dark green fruit. Adaptation: U.S. 2005.

XP 4506116 - Vendor: Seminis. Parentage: hybrid. Characteristics: dark green fruit with white spines; L/D ration of 3.1; well suited for machine picking. Adaptation: U.S. 2005.

\section{EGGPLANT}

Fairy Tale (PS 2409080) - Breeder and vendor: Seminis Vegetable Seeds. Parentage: F1 hybrid. Characteristics: miniature bush plant 18 inches tall; purple and white striped elongated fruit $4 \times 2$ inches; 2004 All America Selections Winner. Adaptation: NAFTAhome garden. 2004.

\section{ENDIVE}

Damsel (SSC 26018) - Breeder and vendor: Shamrock Seed Co. Parentage: open pollinated. Characteristics: Tres Fine Maraichere or
Frisee type; common component in baby leaf salads; produces a medium-large, spreading plant with thick, finely serrated leaves; the plant frame is medium green and has a dense, blanched heart; maturity is 60-65 days during summer in coastal regions and 110 days during winter in desert regions. Resistance: none claimed. Similar: Tres Fine Maraichere. Adaptation: U.S. salad production regions. 2003.

\section{HERBS-PARSLEY}

Geppetto-Breeder and vendor: Meyer Seed International. Characteristics: dark-green Italian parsley; large, glossy, dark-green leaves; excellent recovery and regrowth with a superior aroma. 2005.

Pinocchio - Breeder and vendor: Daehnfeldt/SeedWorks. Characteristics: for commercial herb growers; has a plain, broad leaf that is larger than most parsley; medium-early, very vigorous plant which produces excellent yield. 2001.

\section{LEEK}

Ashton-Breeder and vendor: Nunhems. Parentage: hybrid. Characteristics: long harvest window; suitable for high-density planting; nice dark green color; upright plant habit. 2005.

\section{LETTUCE}

\section{Beiquan Mou \\ USDA/ARS \\ U.S. Agricultural Research Station \\ 1636 East Alisal Street \\ Salinas, CA 93905}

98-A-Breeder: Central Valley Seeds. Vendor: Siegers Seed Co. Characteristics: heavy romaine; dark green and tall with an approximate maturity of 62 days; easy to pack with little breakage and excellent arrival. 1998

Acropolis (SSC 1501) - Breeder and vendor: Shamrock Seed Co. Parentage: open pollinated. Characteristics: sure-heading, hot season iceberg cultivar with remarkable uniformity and consistent performance; produces large, dark green plant frames that provide good head protection; reliably makes large, flattened-round heads with a very smooth shape; large size and thick, crisp texture ensure high yields; very good internal quality. Resistance: tipburn and bolting tolerance. Adaptation: Imperial Valley, California, Yuma, Arizona. Utility Patent \#7,102,606 (issued 9/5/2006). 2004.

Amaze - Breeder and vendor: Shamrock Seed Co. Characteristics: A red Little Gem with excellent uniformity and impressive color; it produces plants with glossy, maroon-red external leaves and an attractive yellow interior; the leaves have a soft, buttery texture and have no red speckling as other red Little Gems. Resistance: Downy Mildew (pathotypes I-VI / BL 1-16, 19, 21, 23). Similar: Dazzle, but Amaze produces slightly smaller plants. Utility Patent 7,453,026 and Plant Breeder's Right pending. 2012.

Annapolis (SSC 1332) - Breeder and vendor: Shamrock Seed Co. Parentage: open pollinated. Characteristics: red romaine type developed for baby leaf salads; glossy, deep wine-red color; medium-broad, club shaped leaf with slightly wavy leaf margins and light serration along the stem; slightly blistered at the 4th true leaf; pliable texture. Resistance: downy mildew (pathotypes I, IIA, IIB, III, IV, V). Similar: Infantry. Adaptation: U.S. lettuce growing regions. 2004

Annie-Breeder and vendor: Asgrow. Characteristics: crisphead type, excellent green color and leaf texture, good heading ability. Resistance: downy mildew (B1 2, 6, 14, 19). Similar: Early Giant, Vanguard. Adaptation: U.S. SW Desert(Sowing dates 9/20-10/5). PVP \#9400156 (issued 3/31/1998). 1993.

Artillery (SSC 30421) - Breeder and vendor: Shamrock Seed Co. Parentage: open pollinated. Characteristics: light green colored Salad Bowl type; smooth textured and highly undulated leaves; 
developed for production as a baby leaf component in spring mix salads; suited for organic and conventional productions. Resistance: downy mildew resistance (pathotypes I, IIA, IIB, III, IV and V). Similar: Standard Green Oak Leaf. Adaptation: U.S. lettuce production regions. 2001.

Badger (GS 6598531) - Breeder and vendor: Seminis Vegetable Seeds-Genecorp. Parentage: open pollinated. Characteristics: Vanguard type iceberg with medium color, good weight and texture; this cultivar is vigorous and sure heading; ideally suited for the late Merit slot (sowing dates 9/28 to 10/15). Similar: Desert Storm. Adaptation: NAFTA-Desert Southwest. 2002.

Bandit (SSC 1611) - Breeder and vendor: Shamrock Seed Co., Inc. Parentage: OP. Characteristics: a very uniform and highly disease tolerant romaine; it produces heavy plants with a thick, moderately blistered leaf texture; trimmed plants are 12-13 inches tall and have an upright structure with a compact base and straight ribs; develops a darker green color than standard PICs; tends to cup-in at maturity and makes nice, dense hearts; its heavy weight, combined with an excellent shape and disease tolerance to Lettuce Dieback, Cork Root and Downy Mildew (pathotypes I-VI) make Bandit the ideal choice for problem fields. Similar: N/A. Resistance: Downy Mildew I-VI, Lettuce Dieback, Corky Root. Adaptation: All lettuce production regions. 2005.

Bennett-Breeder and vendor: Nunhems. Characteristics: excellent color; high yields; crisp leaf texture. 2005.

Beretta (SSC 1121) - Breeder and vendor: Shamrock Seed Co. Parentage: open pollinated. Characteristics: romaine type with consistent performance over a wide range of growing conditions in coastal California and the desert southwest; produces large, dark green plants with an upright structure; leaves have faint blistering, smooth margins and no tendency to cup; plants are 12.5-13 inches tall and weigh $1.75 \mathrm{lb}$; highly tolerant to tipburn; ideal for prepared salads, carton pack and whole leaf products. Adaptation: U.S. lettuce production regions. PVP. 2003.

Bermuda (SSC 1309) - Breeder and vendor: Shamrock Seed Co. Parentage: open pollinated. Characteristics: uniform and widely adapted green leaf type; consistent production of heavy plants with highly frilled, medium-dark green leaves; its supple ribs minimize harvest and packing damage thereby providing better overall quality; good bolting and tipburn tolerance (not suited for slots with high temperature extremes). Similar: a standard green leaf lettuce. Adaptation: all production regions. 2005.

Bidwell (SSC 2985) - Breeder and vendor: Shamrock Seed Co. Parentage: open pollinated. Characteristics: a romaine variety with dark green leaves for baby leaf production. Resistance: Downy Mildew (pathotypes I-VIII / BL 1-20, 22-25, 27). Adaptation: all lettuce growing regions. 2012.

Big Ben M.T.-Breeder and vendor: Pybas Vegetable Seeds. Characteristics: spring and fall variety lettuce; features excellent corky root resistance; produces large, heavy heads; exceptional yield. Resistance: tolerance to sclerotinia; tip burn resistance. 1998.

Big Star-Breeder and vendor: Central Valley Seeds, Inc. Parentage: open pollinated. Characteristics: a green leaf variety with a medium to large frame and a impressive butt and midrib appearance at harvest time; it is very pliable at harvest while exhibiting non-heading abilities with extremely dark green plant color; its strong holding abilities past harvest stage will improve its leaf count while maintaining product quality and weight. Resistance: possesses a strong bolting and tip-burn resistance under extremely warm temperatures with long day lengths. Adaptation: all U.S lettuce production regions. PVP \#200,200,013 (issued 12/12/2005). 2001.

Blackjack M.T.-Breeder and vendor: Pybas Vegetable Seeds. Characteristics: unique and extremely dark red leaf surface lettuce; especially suited for baby leaf and gourmet lettuce products; in the early stages of growth, the entire plant is dark burgundy in color. 1998.

Blockbuster (SSC 1370)—Breeder and vendor: Shamrock Seed Co. Parentage: open pollinated. Characteristics: vigorous, Salinas type iceberg lettuce for carton and processing markets; consistent production of large, heavy heads with a full-round, symmetrical shape; heads have medium-large butt, short core and flat ribs; its large, bright green plant frame offers excellent head protection. Resistance: big vein. Similar: Pacific. Adaptation: early season production for all lettuce growing regions. PVP \#200500183 (issued 11/29/2007). 2004

Bubba (XP 559) - Breeder and vendor: Seminis Vegetable Seeds-Asgrow. Parentage: open pollinated. Characteristics: Iceberg lettuce of Vanguard type; has a large frame and head size and medium green color when compared to Kofa. Adaptation: late winter production; planting schedule: Yuma in October or November; Huron in November. PVP \#9800032 (issued 3/10/2003). 2003.

Burton (SSC 2986) - Breeder and vendor: Shamrock Seed Co. Parentage: open pollinated. Characteristics: a green leaf variety for baby leaf production; unique shape and crunchy texture. Resistance: Downy Mildew (pathotypes I-VIII / BL 1-28). Adaptation: all lettuce growing regions. 2012.

Cadet (SSC 1865) - Breeder and vendor: Shamrock Seed Co., Inc. Parentage: OP. Characteristics: an oak leaf lettuce that produces attractive, wine-red colored leaves with good texture; baby leaves have a medium-broad shape and smooth, wavy margins. Resistance: downy Mildew (CA pathotypes I-VI). Similar: unknown. Adaptation: all lettuce production areas. 2005.

Champion-Breeder and vendor: Shamrock Seed Co., Inc. Parentage: open pollinated. Characteristics: a vigorous iceberg lettuce that produces large plants with good head cover, short cores, good texture, and a fresh green color. Resistance: downy mildew (CA pathotypes I-VIII) and corky root.

Citori (SSC 1128) - Breeder and vendor: Shamrock Seed Co. Parentage: open pollinated. Characteristics: produces uniform, tall and upright plants with very good weight; medium green leaves have smooth margins and a lightly savoyed texture; a compact base and straight ribs make for an attractive shape; thick, blanched hearts. Resistance: corky root. Similar: Parris Island cos. Adaptation: U.S. lettuce growing regions. 2004.

Concept (BOS 9052) - Breeder and vendor: Orsetti Seed Co. Parentage: open pollinated. Characteristics: mildly savoyed, Romainelike green leaf type; heavy butterhead texture; dark color; excellent pliability; supple leaves resist cracking and bruising; leaves are approximately the same dimension through the head; suited for whole leaf market as well as fresh market. Adaptation: U.S. 2001.

Conquistador (PX 0136) - Breeder: Doug Sousa. Vendor: Seminis Vegetable Seeds-Petoseed. Characteristics: tall romaine with glossy, dark green leaves that are semi savoy; superior weight, very uniform maturing, well suited for winter harvest, for fresh pack and hearts. Resistance: corky root rot. Similar: Green Towers. Adaptation: desert southwest U.S. PVP\#200000071 (issued 4/19/2005). 1999.

Cornerstone - Breeder and vendor: Shamrock Seed Co. Parentage: open pollinated. Characteristics: produces a uniform crop of large, medium green iceberg heads protected by a large plant frame; its heads have a smooth, round shape and very crisp leaf texture; large smooth butt. Resistance: downy mildew (CA pathotype I-VI) and corky root. Adaptation: early spring production.

Corporal (SSC 1856) - Breeder and vendor: Shamrock Seed Co., Inc. Parentage: OP. Characteristics: a slow growing red romaine that produces small leaves with an attractive, wine-red color that extends to the base of the leaf; the leaves have the standard romaine shape and are fairly flat but have faintly scalloped leaf margins. Resistance: Downey mildew resistance to be confirmed. Similar: unknown. Adaptation: all lettuce production areas. 2005.

Cosmopolitan (PS 654569) - Breeder and vendor: Seminis Vegetable Seeds-Petoseed. Parentage: open pollinated. Characteristics: unique; shape is similar to Romaine but with a thicker and tougher texture than crisphead lettuce with a dark green color; shape of the head is similar to a Romaine heart. Adaptation: coastal California. 2002.

Coyote (GS 6530201) - Breeder and vendor: Seminis Vegetable Seeds-Genecorp. Parentage: open pollinated. Characteristics: Vanguard type crisphead with medium dark color, short core and large frame; non undulating leaf margin and uniformity; top leaf cover offers good protection from the cold and sun. Similar: Cibola, 
Accolade. Adaptation: U.S. southwest desert October and November plantings. PVP\#200200224 (issued 4/27/2005). 2002.

Darkland Cos-Breeder and vendor: Central Valley Seeds, Inc. Parentage: open pollinated. Characteristics: this romaine has excellent dark green color, heavy leaf texture; has a smooth midrib and has one of the best appearances when packed. Resistance: strong bolt tolerance; has shown tolerance to big vein and less cupping than other romaines. Adaptation: all U.S. lettuce production regions. PVP expired 5/29/2010. 1990.

Darkland Cos EL_-Breeder and vendor: Central Valley Seeds, Inc. Parentage: open pollinated. Similar: similar to Darkland Cos but has some distinct advantages such as, added weight, and later cupping and slightly larger frame. This variety shows excellent shipping quality. The other difference is that Darkland Cos EL has a slightly less bolting tolerance than Darkland Cos. Adaptation: all U.S. lettuce production regions.

Dazzle - Breeder and vendor: Shamrock Seed Co., Inc. Characteristics: A red Little Gem with excellent uniformity and impressive color; it produces plants with glossy, maroon-red external leaves and an attractive yellow interior; the leaves have a soft, buttery texture and have no red speckling as other red Little Gems. Resistance: Downy Mildew (pathotypes I-VI / BL 1-16, 19, 21, 23). Similar: Amaze, but Dazzle produces slightly larger plants. Utility Patent 7,592,510 and Plant Breeder's Right pending. 2012.

Desert Spring-Breeder and vendor: Seminis Vegetable Seeds. Characteristics: crisphead with large frame and relatively smooth leaves, medium-sized core diameter, a flat butt appearance. Resistance: tolerant to tipburn. Adaptation: U.S. southwest desert (planting dates: 11/15-12/15). PVP\#8900299 (issued 12/31/1991).

Excalibur - Breeder and vendor: Shamrock Seed Co. Parentage: open pollinated. Characteristics: a sure heading iceberg type; uniform head size and maturity; smooth round heads have a medium green color and crisp texture; produces heavy heads in the 24's size range; smooth, symmetrical butt. Resistance: downy mildew (CA pathotype I-VI); tipburn and bolting tolerant. Adaptation: main season production in coastal California. Utility Patent \#7,326,829 (issued 2/5/2008). 2006.

Fireball-Breeder and vendor: Johnny's Selected Seeds. Characteristics: more heat tolerant than Red Cross; tastes milder; stays bitter-free longer in hot weather; large, dense heads with creamy yellow centers mature in 51 days. 2005 .

Folsom (SSC 2988) - Breeder and vendor: Shamrock Seed Co. Parentage: open pollinated. Characteristics: a romaine variety with crunchy green leaves for baby leaf production. Resistance: Downy Mildew (pathotypes I-VI, VIII / BL 1-23, 25). Adaptation: all lettuce growing regions. 2012.

Fortress (SSC 1623) - Breeder and vendor: Shamrock Seed Co., Inc. Parentage: OP. Characteristics: a triple-red Lolla Rossa lettuce developed for baby leaf salads; medium to slow vigor, as expected for varieties of this type; leaves have a short, broad leaf shape and frilly margins; produces a uniform crop of wine-red colored leaves with good leaf texture. Similar: Sentry and Sentinel, but with more mildew resistance. Resistance: Downy mildew (Pathotypes I-VI, VIII / BL 1-24). Adaptation: All lettuce production regions. 2005.

Fortunas-Breeder and vendor: Rijk Zwaan. Characteristics: spring to autumn cultivation type; first head lettuce cultivar resistant to Nasonovia ribis-nigri, the green lettuce aphid. 2001.

Garrison (SSC 1366) - Breeder and vendor: Shamrock Seed Co. Parentage: open pollinated. Characteristics: red, oak leaf lettuce developed for baby leaf salads; produces medium wine-red colored leaves (double red); narrow, oak leaf shaped leaves have undulating lobes and smooth leaf margins; very supple texture. Resistance: downy mildew (pathotypes I, IIA, IIB, III, IV, V). Similar: Armada. Adaptation: U.S. lettuce growing regions. 2004.

General (SSC 1878) - Breeder and vendor: Shamrock Seed Co., Inc. Parentage: OP. Characteristics: remarkably thick texture and excellent uniformity characterize this green oak leaf lettuce; at baby leaf maturity, its leaves are a bright, lime-green color and have smooth, wavy leaf margins; the leaf shape is medium-broad and multi-lobed; fairly vigorous growth. Resistance: none. Similar: unknown. Adaptation: all lettuce production regions. 2005.
Green Beret (SSC 1256) - Breeder and vendor: Shamrock Seed Co. Characteristics: very uniform and widely adapted green leaf type; consistent production of heavy plants with highly frilled, medium-dark green leaves; its supple ribs minimize harvest and packing damage thereby providing better overall quality; good bolting and tipburn tolerance (not suited for slots with high temperature extremes). Similar: Two Star. Adaptation: all U.S. lettuce production regions. 2002.

Green Forest-Breeder: Central Valley Seeds, Inc. Vendor: Johnny's Selected Seeds. Characteristics: earlier, a darker green romaine; ribs are smooth so it packs and handles with less damage; a great choice for hearts. Resistance: more tolerant to tip burn and bolting than Green Towers; it is also more tolerant to sclerotinia and corky root. Adaptation: all U.S. lettuce production regions. Patent \#6,649,815 (issued 11/18/2003). PVP \#200,000,013 (issued 2/14/2006). 1998.

Green Vision-Breeder and vendor: Central Valley Seeds, Inc. Parentage: open pollinated. Characteristics: this green leaf cultivar has excellent non-bolting, non-suckering, and non-heading qualities when compared to other varieties; has excellent dark color, weight, and texture. Adaptation: U.S. lettuce production regions. PVP \#9,500,244 (issued 9/30/1999). 1995.

Greenduke (SSC 2558) - Breeder and vendor: Shamrock Seed Co. Characteristics: a vigorous Salinas type iceberg variety that produces plants with large frames and nicely shaped heads; heads have good weight and size, crisp texture and a nice medium green color; adapted to cool growing conditions. Resistance: Downy mildew (CA pathotypes I-VI / BL 1-16, 19, 21, 23). Similar: Salinas. Adaptation: All Lettuce growing regions. 2011.

Heavy Heart (PS 06516262)—Breeder and vendor: Seminis Vegetable Seeds. Parentage: open pollinated. Characteristics: summer romaine is tall yet compact in diameter; slightly dark green in color; slightly closed (producing a heart); has a slightly blistered and large leaf, very little tip burn and bolting tolerant; can be used by processor, fresh market and hearts segments; targeted for the south county in Salinas area; sow dates in Salinas and Santa Maria, California are Mar. 1 to Sept. 1. Similar: Hearts Delight, Bullet. Adaptation: NAFTA-Southwest Coastal U.S. 2004.

Honcho II-Breeder and vendor: Seminis Vegetable Seeds. Characteristics: a dark green Vanguard-type crisphead variety with a large head; moderately sayoyed, heavily textured leaves. Adaptation: U.S. southwest desert (planting date 10/1-10/15). 1988.

Javelina (GS 8365) - Breeder and vendor: Seminis Vegetable Seeds-Genecorp. Parentage: open pollinated. Characteristics: large heading Merit period crisphead for the Desert Southwest; produces round heads with good formation and texture; good yield; best seeding dates are Sept. 20 to Oct. 5 for Yuma, and Sept. 20 to 30 for Imperial Valley. Resistance: downy mildew (CA pathotype II, IV). Similar: Annie, Raider, Hallmark, Jupiter, Mid Queen, Pico Rico, Fortuna. Adaptation: Desert Southwest U.S. PVP\#200200223 (issued 4/27/2005). 2002.

Kessler-Breeder and vendor: Shamrock Seed Co. Parentage: open pollinated. Characteristics: an ideal variety for romaine hearts and processing; it produces dark green plants with a very upright habit and straight ribs; its narrow base and dense, blanched center make an attractive romaine heart; the leaves have a strong texture and are moderately savoyed; has good uniformity and weight. Resistance: corky root. Adaptation: performs best under cool growing conditions.

Kindle (SSC 3033) - Breeder and vendor: Shamrock Seed Co., Inc. Characteristics: An attractive Little Gem with very good mildew tolerance; it produces glossy, lime-green plants that feel heavy for their size; the hearts are dense and have a bright yellow color; leaves with smooth margins, very good texture and a pleasant flavor. Resistance: Downy mildew (CA pathotypes I-VI, VIII / BL 1-25, 28). Adaptation: All Lettuce growing regions. 2012.

Laguna Fresca-Breeder and vendor: Central Valley Seeds, Inc. Parentage: open pollinated. Characteristics: this iceberg variety has a strong texture, long cap leaf coverage, and a savoyed leaf surface; possesses sure-heading abilities. Resistance: corky-root resistance and a very strong tolerance to tip-burn; an exceeding high tolerance 
to bolting during summer planting in the Salinas Valley. Adaptation: all U.S. lettuce production regions. PVP \#200,100,044 (issued 8/25/2005). 2000.

Luxury (SSC 3011) - Breeder and vendor: Shamrock Seed Co., Inc. Characteristics: A new red Little Gem that produces larger, darker red plants with stronger mildew resistance compared to Amaze and Dazzle; nice looking, $20 \mathrm{~cm}$ tall plants with an average weight of $175 \mathrm{~g}$; has blistered leaves with a soft texture and good flavor; the heart is yellow-green with a tinge of red in the center. Resistance: Downy mildew (CA pathotypes I-VI / BL 1-25, 28). Adaptation: All Lettuce growing regions. 2012.

M 22505-Breeder and vendor: Enza Zaden. Parentage: open pollinated. Adaptation: North America. 1997.

Marshall (SSC 1532) - Breeder and vendor: Shamrock Seed Co., Inc. Parentage: OP. Characteristics: a fast growing romaine that produces wine-red to slightly maroon colored leaves; baby leaves have a standard romaine shape (broad club) and a smooth, mediumthick texture; its undulating leaf margins are smooth at the top and slightly scalloped along the tapering sides. Resistance: Downey mildew (pathotypes I-VI). Similar: Red Cos. Adaptation: All lettuce production regions. 2005.

Militia (SSC 1349) — Breeder and vendor: Shamrock Seed Co. Parentage: open pollinated. Characteristics: medium wine-red oak leaf lettuce; it produces moderately broad, multi-lobed leaves with a wavy appearance and smooth leaf margins; smooth, pliable texture. Resistance: downy mildew (pathotypes I, IIA, IIB, III, IV, V). Similar: Armada. Adaptation: U.S. lettuce growing regions. 2004.

Nero-Breeder and vendor: Genecorp. Characteristics: very dark colored romaine; extremely thick, blistered surface leaf that allows for a heavy plant weight; plant is slow closing. Resistance: resistant to corky root. 1998.

Pacheco (RS 06476304) - Breeder and vendor: Seminis. Parentage: open pollinated. Characteristics: large, outdoor, dark green, closed heading butterhead type; excellent weight and tip burn tolerance; nice leaf texture and smooth leaf surface; slightly larger/ darker and better heading then Baja, with much improved uniformity; suitable for year round sowings in NAFTA; Coastal California Jan. 15-July 30; Yuma Oct. 10-Dec. 30. Resistance: downy mildew Bremia lactucae CA Pathotype I, IIA, IIB, III, IV; intermediate to downy mildew Bremia lactucae CA Pathotype V. Similar: Bennett, Optima. Adaptation: NAFTA-Southwest Coastal California. 2005.

Parthenon (SSC 1315) - Breeder and vendor: Shamrock Seed Co. Parentage: open pollinated. Characteristics: very uniform and sure heading cultivar similar in production to Winterhaven; plant frame is large and offers good frost protection; produces large, heavy heads with a slightly savoyed leaf texture; heads have a nice, smooth shape and good color. Resistance: big vein. Similar: Colossus. Adaptation: desert Southwest (USA) and winter production. 2004.

Passport (174261) - Breeder and vendor: Seminis Vegetable Seeds. Parentage: open pollinated. Characteristics: dark green mini sized romaine for open field cultivation; suitable for autumn, winter and spring production; good tipburn tolerance. Similar: Pinokkio. Adaptation: NAFTA. 2004.

PIC 714-Breeder and vendor: Johnny's Selected Seeds. Characteristics: uniformity; improved tolerance to tip burn; heavy heads average 11 to 12 inches tall with good taste; days to maturity are 28 days for baby, 57 days full size. Resistance: some tolerance to corky root. 2005.

Raider-Breeder and vendor: Seminis Vegetable Seeds-Genecorp. Characteristics: crisphead lettuce in the Vanguard class; produces a wide petiole and large core diameter; leaf surface and midribs are relatively smooth; excellent header. Resistance: downy mildew (B1 2, 6, 14, 19). Adaptation: U.S. southwest desert, suitable for late fall harvest (plant date 9/10-9/25). 1989.

Rebellion (SSC 1536) - Breeder and vendor: Shamrock Seed Co., Inc. Parentage: OP. Characteristics: uniform, medium red (double-red) Lollo Rossa developed for full head production; it produces symmetrical plants attain a $20-\mathrm{cm}$ spread and $15-\mathrm{cm}$ height. Similar: Dark Lollo Rossa. Resistance: Downy Mildew CA I-V;/BL 1-16, 19, 21, 23. Adaptation: All lettuce growing regions. 2005.
Red Bull (PS 06515636) - Breeder and vendor: Seminis Vegetable Seeds. Parentage: open pollinated. Characteristics: very large looseleaf type; dark red with smooth leaf margin and smooth leaf surface; wide adaptation; tip burn and bolting resistant. Similar: Red Chalte, New Red. Adaptation: NAFTA, southwest coastal U.S. PVP application \#200500042. 2005.

Red Fox-Breeder and vendor: Central Valley Seeds, Inc. Parentage: open pollinated. Characteristics: this red leaf variety shows excellent color; it is non-heading with frilly leaf margin, and has a high leaf count; has superb shipping qualities due to its texture and one of best box appearance; weight is comparable or better than most reds in market place. Resistance: excellent bolt tolerance; has extremely high resistance to internal tip-burn for early desert regions. Adaptation: all U.S. lettuce production regions. PVP \#9,700,357 (issued 6/14/2001). 1997.

Red Rage M.T.-Breeder and vendor: Pybas Vegetable Seeds. Characteristics: attractive, dark red and uniform loose leaf variety; suitable for baby leaf or fresh market production; completely green midribs provide a beautiful contrast to the dark red leaf surface. 1998. Rome 59 (HMX 4559) - Breeder and vendor: Harris Moran Seed Co. Characteristics: new Romaine; yields a highly uniform, 1.75-lb head with excellent core length; high yield potential; adaptable to a wide range of growing areas; relative maturity: mid. 2005.

Rex RZ-Breeder and vendor: Rijk Zwaan. Characteristics: standard butterhead lettuce for greenhouse production or NFT. Resistance: bolting and tipburn. 2001.

Rhino (PS 06510524) - Breeder and vendor: Seminis. Parentage: open pollinated. Characteristics: Iceberg for desert (Southwest U.S.) plantings, medium green, large frame, short core length, good head wrap for protection from sun and cold, non undulating leaf margin and very uniform; has the potential to form a large heavy head; sowing dates Nov. 25 to Dec. 15; harvest Mar. 10 to Mar. 31. Similar: Green Lightening, Desert Spring. Adaptation: NAFTASouthwest United States. 2005.

Sahara (GS 06511294) - Breeder and vendor: Seminis Vegetable Seeds-Genecorp. Parentage: open pollinated. Characteristics: crisphead type, suitable for high temperature regions, large frame, medium green leaves. Resistance: downy mildew (Bl 1, 2, 6, 14, 19); outstanding bolting tolerance; tipburn-tolerant. Similar: Sun Devil, Beacon, Light House, Valley Green. Adaptation: Desert Southwest U.S. and Huron, California. Best early season planting in Huron on Aug. 13-25, Yuma on Sept. 5 to 20, spring or summer market on June 1 to Sept. 1; Chile on Dec. 1 to Jan. 30. PVP\#200300143 (issued 12/12/2005). 2002.

San Simeon (SSC 2987) - Breeder and vendor: Shamrock Seed Co. Parentage: open pollinated. Characteristics: a green leaf variety for baby leaf production; it produces savoyed leaves. Resistance: Downy Mildew (pathotypes I-VIII/BL 1-28). Adaptation: all lettuce growing regions. 2012.

Sentinel (SSC 1402) - Breeder and vendor: Shamrock Seed Co. Parentage: open pollinated. Characteristics: triple-red Lollo Rossa type developed for baby leaf salads; medium to slow vigor, as expected for this type; leaves have a short, broad leaf shape and frilly margins; produces a uniform crop of wine-red colored leaves with good leaf texture. Resistance: DMR I-VI (Bremia BL 1-16, 19, 21, 23). Similar: Sentry. Adaptation: all lettuce production regions. 2005.

Sergeant (SSC 1877)—Breeder and vendor: Shamrock Seed Co., Inc. Parentage: OP. Characteristics: a variety in the Tango class with thicker texture and darker, lime-green color; produces multilobed leaves with spiky, undulating leaf margins; its growth rate is similar to that of Tango. Resistance: none. Similar: Tango. Adaptation: all lettuce production regions. 2005.

Sharpshooter-Breeder and vendor: Seminis Vegetable Seeds. Characteristics: crisphead with good leaf texture, head density, and uniform maturity; high yield and good adaptability. Resistance: corky root; downy mildew (CA pathotype II, III, IV). Adaptation: Main season in coastal and inland California (Planting date: coastal and mid Salinas valley: 2/25-7/15; inland: 2/15-5/15). U.S. Patent\#5, 973,232 (issued 10/26/1999). 1997. 
Sicily (GX 923)-Breeder and vendor: Seminis Vegetable Seeds-Genecorp. Parentage: open pollinated. Characteristics: spring mix, red frilly type, triple red Rossa type with excellent texture and very frilly leaf margin. Similar: Lolla Rossa. Adaptation: California coast and cooler climate planting conditions. 2002.

Silverwood (SSC 2989) - Breeder and vendor: Shamrock Seed Co. Parentage: open pollinated. Characteristics: a green leaf variety for baby leaf production; it produces crunchy leaves. Resistance: Downy Mildew (pathotypes I-VIII / BL 1-23, 25). Adaptation: all lettuce growing regions. 2012.

Spanish Bay-Breeder and vendor: Genecorp. Characteristics: iceberg lettuce variety; medium green color; excellent texture; it is a sure header with a large frame. Resistance: resistant to corky root. 1998.

Spartacus - Breeder and vendor: Shamrock Seed Co. Parentage: open pollinated. Characteristics: an iceberg variety with very uniform head formation; it produces heavy heads with good size; the heads have a smooth, round shape, clean butts and a short core; it makes an ample plant frame that ensures head protection. Resistance: the heads sit off the bed resulting in a lower incidence of bottom rot; tipburn and bolting tolerant. Utility Patent \#7,960,617 (issued 6/14/2011). 2008.

Sparx-Breeder and vendor: Shamrock Seed Co. Parentage: open pollinated. Characteristics: produces large, heavy romaine plants that cup and blanch early. Resistance: extremely burn resistant for fog/inversion burn and internal tipburn in the difficult summer slot in these Coastal areas (even behind Strawberries); downy mildew (CA pathotype I-VI), and corky root. Similar: Stryker. Adaptation: ideal for production in the mid-season slot and is specifically targeted to the Coastal production areas of Blanco, Castroville and Watsonville.

Spreckles-Breeder and vendor: Genecorp. Characteristics: dark green color with a medium frame; excellent uniformity and sure heading ability; bred for early spring harvest in Coastal areas and early winter in the desert Southwest. Resistance: resistance to big vein. 1998

Squadron (SSC 30543) - Breeder and vendor: Shamrock Seed Co. Parentage: open pollinated. Characteristics: baby leaf type that produces thick textured leaves with frilly leaf margins and a dark, lime green color; suitable as a replacement for Tango, particularly under downy mildew incidence; also has applications as a full grown product in certain markets. Resistance: downy mildew resistance (pathotypes I, IIA, IIB, III, IV and V). Similar: Waldmann's Green. Adaptation: U.S. lettuce production regions. 2002.

Stealth (SSC 1866) - Breeder and vendor: Shamrock Seed Co., Inc. Parentage: OP. Characteristics: an oak leaf lettuce that produces attractive, wine-red colored leaves with good texture; baby leaves have a medium-broad shape and smooth, wavy margins. Resistance: Downey Mildew (pathotypes I-VI, VIII). Similar: unknown. Adaptation: all lettuce growing regions. 2005.

Stryker-Breeder and vendor: Shamrock Seed Co. Parentage: open pollinated. Characteristics: a solid-ribbed, heavy romaine lettuce that is suitable for processing, hearts and cartons; produces large plants that cup and blanch early allowing for harvest flexibility. Resistance: has remarkable tolerance to fog/inversion burn as well as internal tipburn; downy mildew (CA pathotype I-VI); corky root. Similar: Sparx. Adaptation: ideal for production in the early and mid-season slots throughout the Salinas Valley.

Sunbelt-Breeder and vendor: Central Valley Seeds, Inc. Parentage: open pollinated. Characteristics: a warm weather romaine; exhibits a large frame with a 12- to 14-inch plant height; it is extremely noncupping at harvest time; has an extremely smooth midrib and wide leaf petiole with a straight tapered butt shape, which makes for an impressive pack at harvest time; has excellent hold-ability at past optimum maturity, which would help processor salad trade. Resistance: Along with its strong bolting resistance and high tolerance to tip burn, it's tolerant to fringe burn during warm windy days in the Salinas Valley. Adaptation: all U.S. lettuce production regions. U.S. Patent \#6,841,723 (issued 1/11/2005). 2003.

Sure Shot (PX 06512772) - Breeder and vendor: Seminis Vegetable Seeds-Petoseed. Parentage: open pollinated. Characteristics: attractive crisphead, minimal ribbyness, medium dark exterior cover and wrap with a short core; uniform round shape and flat bottom makes it suitable for fresh, cello, or process type; dense interior with minimal space between internodes makes this cultivar heavy and firm. Resistance: downy mildew (CA pathotype I-IV, V (partial), big vein, corky root rot. Similar: Trojan, Jupiter, Big Ben, Pybas 251. Adaptation: Southwest Coastal California. PVP \#200000066 (issued 3/21/2005). 2002.

Thermo Cos-Breeder and vendor: Central Valley Seeds, Inc. Parentage: open pollinated. Characteristics: a romaine with medium frame size; with medium plant height; the leaf texture is extremely thick with dark green color, with open growing habit. Similar: Thermo Cos is a sister line of Green Forest; it maintains the same strong attributes as other sister lines; the advantage of Thermo Cos is its high bolting and strong tip-burn tolerances over most commercial lines. Adaptation: all U.S. lettuce production regions, it is especially adaptable to higher temperature growing areas in the Monterey and San Benito Counties. U.S. Patent \#6,649,816 (issued 1/18/2003). PVP \#200,100,135 (issued 2/14/2006). 2001.

Top Billings-Breeder and vendor: Seminis Vegetable Seeds. Characteristics: sure heading crisphead, large, dark-green frame and cap leaves provide excellent head protection, produce a large head suitable for both fresh market and bulk harvest. Adaptation: Southwest U.S. Desert region (planting dates: 11/1-11/15).

Top PIC (SSC 1603) - Breeder and vendor: Shamrock Seed Co., Inc. Parentage: OP. Characteristics: a romaine lettuce of the Parris Island Cos type; produces medium tall (11-13 inches) plants with an open habit and a medium base; its leaves are medium green and have a slightly blistered texture and smooth margins; mature pieces attain good weight due to high leaf density; relative maturity is $80-100$ days in early spring and 60-65 days in summer; adapted to regions with mild spring and summer weather (not recommended for production in hot climates). Similar: Parris Island Cos. Resistance: None. Adaptation: All lettuce production regions. 2005.

Tourist (164553) - Breeder and vendor: Seminis Vegetable Seeds. Parentage: open pollinated. Characteristics: dark green romaine type, leaves large size, shiny color, slightly blistered (savoyed); compact plant, cold tolerant, good weight, bolting tolerant. Resistance: downy mildew (BL 01-16, 19, 21, 23). Similar: Bacio, Remus. Adaptation: NAFTA. 2004.

Triple Threat (PS 06516604) - Breeder and vendor: Seminis Vegetable Seeds. Parentage: open pollinated. Characteristics: Romaine, Paris Island Cos type; medium green color; slightly closed, slightly blistered large leaf; very tolerant to tip burn and bolting; can be used by processor, fresh market and hearts segment; suggested sow dates: Mar. 1 to Sept. 15. Similar: Green Towers, Hearts Delight. Adaptation: Southwest Coastal U.S., NAFTA. 2004.

Trophy_Breeder and vendor: Shamrock Seed Co. Parentage: open pollinated. Characteristics: a vigorous iceberg variety that produces large plants with good head cover; its large heads have good weight, good texture and a fresh green color; it will yield shapely heads with short cores when grown in the proper slot. Resistance: downy mildew (CA pathotype I-VIII) and corky root. Similar: Champion.

Valley Heart (RX 06511508) - Breeder and vendor: Seminis Vegetable Seeds. Parentage: open pollinated. Characteristics: Romaine type; medium green color, slightly blistered and large leaf, semi closed, narrow bottom, tall growth habit; non-glossy leaves, smooth leaf margin; very good cold tolerance combined with good bolting and tip burn tolerance; can be used by processor for fresh and hearts segments. Similar: King Henry, Green Towers. Adaptation: NAFTA, southwest coastal, cool season desert U.S. (planting dates: 9/10-9/30 and 11/25-end of season). PVP \#200,500,041 (issued 6/29/2007). 2005.

Veteran (SSC 1212) - Breeder and vendor: Shamrock Seed Co., Inc. Parentage: OP. Characteristics: a butter lettuce with excellent uniformity; produces light green colored plants with a smooth texture and very smooth leaf margins. Similar: N/A. Resistance: DMR CA I-VI. Adaptation: All lettuce production regions. 2005.

Winter Select (PS 06510783) - Breeder and vendor: Seminis Vegetable Seeds. Parentage: open pollinated. Characteristics: large frame, medium green iceberg type that is sure heading; smooth ribs and very vigorous habit, good weight and very finished bottom; 
refined appearance makes it attractive for the cello market; suggested sowing dates are Oct. 15-25. Similar: Cibola, Grizzly. Adaptation: NAFTA - desert (Imperial Valley of California and Yuma, Arizona). 2004.

Yuri (RX 06511530) - Breeder and vendor: Seminis Vegetable Seeds-Royal Sluis. Parentage: inbred. Characteristics: Iceberg lettuce suitable for moderate to high temperature and humidity; Vanguard type, large frame, medium green color, round shape, with good bolting tolerance; recommended sowing period in Brazil is 1 Mar. though 25 June; sowing period in the Caribbean is September through November; performed very well in elevations between 600 and 1500 m. Similar: Legacy. Adaptation: Brazil. 2003.

\section{MELON}

James D. McCreight
USDA/ARS
U.S. Agricultural Research Station
1636 East Alisal Street
Salinas, CA 93905

ACampeon-Breeder and vendor: Abbott \& Cobb Inc. Characteristics: this main-season cantaloupe with round-to-short oval fruit and a small seed cavity is well-suited to shipping; this variety compliments ACompadre for a Western shipper package. Resistance: powdery mildew 1 and applied sulfur. 2005.

ACimarron-Breeder and vendor: Abbott \& Cobb. Characteristics: Western shipper cantaloupe; high-quality, tight-cavity fruit matures in 81 days; the plants are medium sized; excellent disease resistance to Fusarium 1 and 2 and powdery mildew 1. 2001.

ACompadre - Breeder and vendor: Abbott \& Cobb Inc. Characteristics: a "home run" for the second early class; this Western shipper variety offers a high-quality fruit with a small, slightly open cavity; shipping is easy with the round-to-short oval fruit. Resistance: Fusarium wilt race 0 and 1, powdery mildew 1. 2005.

Aphrodite - Breeder and vendor: Syngenta Seeds, Inc./Rogers Brand. Characteristics: larger Athena-type melon; fruit have weighed in around 6 to $7 \mathrm{lb}$ with maturity about 3-5 days earlier than Athena; shown an improved fruit net. Resistance: Fusarium, applied sulfur. Adaptation: Eastern U.S. 2005.

Cabrillo (XP 3910848) - Breeder and vendor: Seminis Vegetable Seeds-Asgrow. Parentage: F1 hybrid. Characteristics: large, round, firm fruit, high Brix, small seed cavity, good flesh color, strong plant with good yield and uniformity. Resistance: Fusarium wilt (races 0-1, 2). Similar: Orio Rico, Cruiser, Ovation. Adaptation: NAFTA-western shipper main season. 2004.

Carmen (SSC 115) - Breeder and vendor: Shamrock Seed Co. Parentage: F1 hybrid. Characteristics: honeydew type; highly prolific, late season maturity; strong vines have a large canopy that provides excellent fruit cover; concentrated fruit set; sets well under a variety of field conditions; sizes mainly $4 \mathrm{~s}$ and $5 \mathrm{~s}$ with some $6 \mathrm{~s}$; sulfur tolerant; relative maturity is $90-95$ days. Resistance: powdery mildew (race 2); Fusarium (races 0, 2). Adaptation: all melon production regions. 2005.

Caroline (SSC 110) - Breeder: and vendor: Shamrock Seed Co. Parentage: F1 hybrid. Characteristics: honeydew type; very prolific, early season honeydew melon; uniform production of smooth, round fruit in the 4, 5 and 6 size range; firm fruit with a small blossom scar and small to medium seed cavity; light green flesh with high sugars. Resistance: powdery mildew (race 2), Fusarium (race 0 and 2). Similar: Morning Ice. Adaptation: all melon growing regions. 2003.

Cassandra (SSC 118)-Breeder and vendor: Shamrock Seed. Parentage: F1 hybrid. Characteristics: hybrid honeydew melon with strong vines and good fruit set; produces smooth, oval-round fruit with a small to medium seed cavity; fruit sizes are $4 \mathrm{~s}, 5 \mathrm{~s}$ and $6 \mathrm{~s}$; sweet, pale green flesh; relative maturity is $85-90$ days. Resistance: tolerant to Fusarium wilt (races 0, 2). Adaptation: U.S. melon producing areas. 2004.

Cobra-Breeder and vendor: D. Palmer Seed. Characteristics: cantaloupe that features strong vine growth with full, dark green leaves; maturity is approximately 110 to 120 days; fruit is oval/round and strongly netted; flesh color is dark to medium orange; flavor is rated very sweet. 1998 .

Destacado (PS 03902039) - Breeder and vendor: Seminis Vegetable Seeds. Parentage: F1 hybrid. Characteristics: main season Honeydew type with very strong and vigorous plant and excellent fruit set; fruit are round in shape, large in size $(2-2.5 \mathrm{~kg})$, with good internal quality, medium to small seed cavity, firm flesh; high yield; develops an external color change from cream to light yellow at maturity. Similar: Sundew, Twilight. Adaptation: NAFTA-Mexico, Chile, Argentina. 2004.

Esteem (RML 7923) - Breeder and vendor: Syngenta, Rogers Brand. Characteristics: exceptionally strong plant that produces large fruit with a raised ropey net with excellent net density; later in maturity than Sol Real with a less concentrated harvest. 2001.

Florentino (191915) — Breeder and vendor: Seminis. Parentage: F1 hybrid. Characteristics: non-sutured; long shelf life; main season Italian type; round shape; full netted; orange flesh; small seed cavity; fruit weight from 800 to $1600 \mathrm{~g}$, grey-green mature rind, medium plant vigor. Resistance: Powdery Mildew race 1, Fusarium wilt race 2 (SA), Fusarium wilt race $0-1$, races 2 (US). Similar: Harper. Adaptation: Central America. 2005.

Gold 264 (PS 03792264) - Breeder and vendor: Seminis Vegetable Seeds-Petoseed. Parentage: F1 hybrid. Characteristics: strong, very vigorous and dark green plant with high and concentrated fruit setting; plant stays green even when fruits are becoming mature; very early maturity, uniform oval/round shape, bright yellow color and slightly rough skin; fruit size varies between 1.24 to $1.45 \mathrm{~kg}$. Similar: AF 646, Rochedo, Gold Pride, Gold Mine. Adaptation: Brazil. 2003.

Gold Coast-Breeder and vendor: Sakata Seed America, Inc. Characteristics: medium-large Western shipper cantaloupe; averages $9 \mathrm{~s}, 12 \mathrm{~s}$, and $15 \mathrm{~s}$ with mid maturity; round-oval shape; ropey net; small cavity; dark-orange flesh. Adaptation: trialed well in the Imperial Valley, Central Arizona, and the San Joaquin Valley. 2005.

Gold Express-Breeder and vendor: Syngenta Seeds, Inc./ Rogers Brand. Characteristics: a Western shipper for true main season conditions typically with medium-to-large fruit size and an excellent dense net for a superior appearance; designed for prolonged harvest conditions; excellent internal quality featuring a tight seed cavity and dark, firm flesh. 2005.

Haley (SSC 114) - Breeder and vendor: Shamrock Seed Co. Parentage: F1 hybrid. Characteristics: honeydew type; broad adaptation; strong vines produce fruit in the $4 \mathrm{~s}, 5 \mathrm{~s}$ and $6 \mathrm{~s}$ size range; fruit has smooth rind, rounded shape and small to medium seed cavity; compares to Samantha but 3 to 5 days earlier in maturity. Resistance: none claimed. Similar: Honeydew, Green Flesh. Adaptation: U.S. melon growing regions. 2003.

Honeycomb - Breeder and vendor: American Takii, Inc. Parentage: hybrid. Characteristics: small seed cavity, thick flesh, very smooth skin; excellent flavor, early maturity; uniform fruits, high yields. Resistance: intermediate resistance to powdery mildew and strong against sulfur. 2005.

Isabella (PS 152140) - Breeder and vendor: Seminis Vegetable Seeds-Petoseed. Parentage: F1 hybrid. Characteristics: netted type with sutures; Charentais flavor, taste and flesh; good shelf life with good holding ability in field; fruit size is approximately 1 to $1.5 \mathrm{~kg}$, depending on growing area and conditions. Resistance: Fusarium wilt, powdery mildew. Similar: none. Adaptation: NAFTA, Mexico, Central America. 2002.

Joaquin Gold (RML 7935) - Breeder and vendor: Syngenta, Rogers Brand. Characteristics: excellent interior quality, tight cavity, thick dark-orange flesh; internal quality similar to the 'Sol' series, but with later maturity and less concentrated harvest. 2001.

Magno (HMX 6583) - Breeder: Bill Copes. Vendor: Harris Moran. Parentage: F1 hybrid. Characteristics: western shipping cantaloupe; early maturing; large fruit, round, full-netted. Adaptation: U.S. 2001.

Motagua-Breeder and vendor: Syngenta Seeds, Inc./Rogers Brand. Characteristics: early maturing melon with a very attractive complete, medium-raised dense net and rich orange flesh; has a strong, healthy vine that delivers attractive medium-to-large-size 
fruit with improved quality. Adaptation: has received favorable growing reports from several growing areas. 2005.

Orange Star (PS 14611013) - Breeder and vendor: Seminis. Parentage: F1 hybrid. Characteristics: Eastern type with good internal quality, fruits are $2.0-2.5 \mathrm{~kg}$, round; small seed cavity with deep orange, firm flesh; uniform net and slight suture; matures in 78-80 days. Resistance: powdery mildew races 1 and 2 (US). Similar: Athena. Adaptation: NAFTA-Southeast U.S. 2005.

PXC 221-Breeder and vendor: Siegers Seed. Parentage: F1 hybrid. Characteristics: alternative hybrid Eastern shipper-type cantaloupe with better yield and consistent netting and uniformity; has minimal sutures; weighs 5 to $6 \mathrm{lb}$. Resistance: tolerant to sulfur, Fusarium races 0, 1, and 2; powdery mildew 1 and 2. 2001.

QCA 044-Breeder and vendor: Sutter Seeds. Characteristics: large size and closed cavity on a strong vine. Resistance: Fusarium wilt races 0, 1, and 2; powdery mildew. 2001.

Rocket (HMX 0588) - Breeder: Bill Copes. Vendor: Harris Moran. Parentage: F1 hybrid. Characteristics: cantaloupe type; strong vine; excellent interior; firm fruit; strong net; mid-early maturity; round to slightly oval fruit. Adaptation: Mexico, Southwest US, Latin American North, Australia. 2002.

Royal Sweet-Breeder and vendor: American Takii, Inc. Characteristics: unique orange flesh; honey-dew-type melon with small seed cavity and excellent uniformity; early maturing; good storage ability; produces large fruit. Resistance: intermediate resistance to powdery mildew, strong against sulfur. 2005.

Samantha (SSC 112) — Breeder and vendor: Shamrock Seed Co. Parentage: F1 hybrid. Characteristics: widely adapted honeydew type; produces attractive, round fruit with crisp flesh; heavy production of $4 \mathrm{~s}$ and $5 \mathrm{~s}$, with a few $6 \mathrm{~s}$; small to medium seed cavity and small blossom scar. Resistance: none claimed. Similar: Honeydew, Green Flesh. Adaptation: U.S. melon growing regions. 2003.

Serenade - Breeder and vendor: Seminis. Characteristics: singleserve specialty melon between the size of a baseball and a softball; features smooth, greenish white skin like Sweetie No. 6; thick orange flesh is rich, sweet, and aromatic; matures in 78 days. 2005.

Snow Mass-Breeder and vendor: Sakata Seed America, Inc. Characteristics: medium-sized honey-dew $(5 \mathrm{~s}, 6 \mathrm{~s}, 8 \mathrm{~s})$; excellent fruit quality; very smooth rind, yields round to slightly oblong fruit; cavity is tight with light green, very sweet flesh (13\% to $15 \%$ Brix); large leaf size; vigorous vine; excellent foliage cover to heavy fruit set. 2005.

Sophia (SSC 116) - Breeder and vendor: Shamrock Seed Co. Parentage: F1 hybrid. Characteristics: early maturing (80-85 days), honeydew type; uniform fruit size and shape; strong vines set high numbers of fruit (size 5 to 6) with small seed cavity; fruit has an attractive, round, smooth shape and high sugar content; good field holding capacity. Resistance: powdery mildew (race 2), Fusarium (race 0,2), sulfur. Similar: Honeydew Green Flesh. Adaptation: U.S. melon production regions. 2003.

\section{OKRA}

Dardo (PS 11589) - Breeder and vendor: Seminis Vegetable Seeds-Petoseed. Parentage: F1 hybrid. Characteristics: small plant, leaves more serrated, semi round type for Brazil; early maturing, 30 days earlier than current leader Santa Cruz 47. Similar: Santa Cruz 47. Adaptation: Brazil. 2002.

\section{ONION}

Michael J. Havey
USDA/ARS, Department of Horticulture
University of Wisconsin
Madison, WI 53706

Affirmed (XP 07715813) - Breeder and vendor: Seminis. Parentage: hybrid. Characteristics: hybrid yellow onion with bronze skin and high single centers; this variety is a mid season Spanish long day onion; 122 days to maturity, with good scale cover for mechanical harvest; bolt tolerant. Similar: Ranchero, Granero. Resistance: Fusarium basal rot. Adaptation: NAFTA-Northeast U.S. 2005.

Amber (SSC 1174) - Breeder: Enza Zaden. Vendor: Shamrock Seed Co., Inc. Parentage: hybrid. Characteristics: a high yielding and later maturing Short Day onion; develops a tall, strong green top and an excellent root system; produces very firm, globe-grano shaped bulbs with mild to moderately pungent flavor; bulbs are predominantly jumbo in size and exhibit a high percentage of single centers (70-80\%); attractive dark, golden-brown skins with good retention and necks that cure down well; very good storage capacity for its type and maturity class. Resistance: field tolerance to Pink Root. Similar: Yellow Grano. Adaptation: Intermediate day latitudes. 2005.

Azteca-Breeder and vendor: Sakata Seed America, Inc. Characteristics: white supreme-type onion with a uniform flat globe; short day onion; large; hard firmness, low pungency; good storage ability; medium neck. Adaptation: Mexico, the Imperial Valley, Texas, and Arizona. 2005.

Cabot (XP 07715676) - Breeder and vendor: Seminis. Parentage: hybrid. Characteristics: long day onion; mid season storage onion with very good storage potential, very high bulb yield which results in high per acre pack outs; bulbs are firm, uniform with excellent skin retention for mechanical harvest. Similar: Millenium (Sunseeds); Prince (Bejo). Resistance: Fusarium basal rot. Adaptation: NAFTA-Northeast U.S. 2005.

Caveat (XP 07718117) - Breeder and vendor: Seminis. Parentage: Hybrid. Characteristics: large early maturing long day Spanish storage type onion, with long storability; attractive dark scales; consistent sizes; bulbs are blocky globe shape with thin necks. Similar: Frontier. Resistance: Fusarium basal rot (FBR). Adaptation NAFTA-Northeast and Northwest. 2005.

Century (XP 07592000) - Breeder and vendor: Seminis Vegetable Seeds-Asgrow. Parentage: F1 hybrid. Characteristics: yellow Granex short day type; similar to Pegasus but earlier; high percentage of colossal and jumbo sizes; good storage ability; excellent flavor and low pungency. Resistance: pink root, Fusarium basal rot. Similar: Melody, Sweet Vidalia, Savannah Sweet. Adaptation: Southeast U.S.; Vidalia, Georgia. 2002.

Champlain (XP 07715776)-Breeder and vendor: Seminis. Parentage: hybrid. Characteristics: long day onion; storage onion, matures in 95 days, bulbs are uniform with good skin retention for mechanical harvest; storage is excellent for an early shipping onion. Similar: Norstar (Takii); Wolf (Takii). Resistance: Fusarium basal rot. Adaptation: NAFTA-Northeast U.S. 2005.

Charismatic (PS 725299) - Breeder and vendor: Seminis Vegetable Seeds. Parentage: F1 hybrid. Characteristics: yellow Spanish type with dark bronze skin and high single centers; full season; good scale cover; bolting tolerant; for machine harvest. Similar: Torero, Vision. Adaptation: NAFTA. 2005.

Citation (EX 07717004) - Breeder and vendor: Seminis. Parentage: hybrid. Characteristics: mid season, long day, Spanish storage type, good scale cover for machine harvest, bolt tolerant, single centered, adapted to overhead watering culture. Similar: Tamara, Teton. Adaptation: NAFTA—Northwest U.S. 2005.

Damascus (XP 07718112) - Breeder and vendor: Seminis. Parentage: Hybrid. Characteristics: mid season Spanish long day storage onion; high yielding; bolt tolerant. Similar: Tamara. Resistance: Fusarium basal rot (FBR). Adaptation: NAFTA-Pacific Northwest. 2005.

Exacta (XP 07906876) - Breeder and vendor: Seminis Vegetable Seeds. Parentage: F1 hybrid. Characteristics: Sweet Spanish type; intermediate day maturity; tops are glossy and bright green and neck is long and thin; single-centeredness is excellent; storage capability is medium. Resistance: Fusarium basal rot, pink root. Similar: Renegade, Excursion, Candy. Adaptation: NAFTA processing areas, Pacific Northwest U.S. 2004.

Gallop-Breeder and vendor: American Takii, Inc. Parentage: hybrid. Characteristics: early maturing; upright plant habit; hybrid bunching onion with strong vigor and excellent uniformity; high 
tolerance to cold and hot temperatures, performs especially well in the heat; medium splitting type. 2005.

Golden Spike (XP 07777025) - Breeder and vendor: Seminis Vegetable Seeds-Asgrow. Parentage: F1 hybrid. Characteristics: late intermediate type, 103-day maturity, dark skin, round bulbs have good size and excellent quality traits. Similar: Renegade. Adaptation: worldwide. 2002.

Grano 6835 (XP 07596835) - Breeder and vendor: Seminis Vegetable Seeds-Asgrow. Parentage: F1 hybrid. Characteristics: very early maturing short day yellow onion; shape is round; average size is small to medium; low percentage of jumbos produced. Similar: Ultra, Grand Prix. Adaptation: Venezuela. 2003.

Highlander - Breeder and vendor: American Takii, Inc. Parentage: hybrid. Characteristics: extra-early maturing (85-90 days); long-day Northeastern type; generally larger in size than Norstar; excellent yields; slow bolting. Adaptation: fresh and short-storage markets. 2005.

Honey Bee (SSC 33076) — Breeder and vendor: Shamrock Seed. Parentage: F1 hybrid. Characteristics: very early maturing short day onion; highly disease tolerant, dark blue-green tops; good yields of bulbs weighing 250-300 g; bulbs have a flattened-globe shape, very small necks and attractive, yellow to light brown skins; very firm bulbs with extra sweet flavor and medium storage capacity. Resistance: Botrytis Leaf Blight, Stemphylium Blight, Purple Blotch. Adaptation: U.S. short day onion production areas. 2002.

Honeycomb (SSC 6372) - Breeder and vendor: Shamrock Seed. Parentage: F1 hybrid. Characteristics: main season maturity; short day type; developed for fresh market; it produces attractive Granex shaped bulbs with low pungency; yields a high percentage of jumbo sized bulbs with straw colored skins; excellent disease tolerance; good bolting tolerance. Resistance: Botrytis Leaf Blight, Purple Blotch. Adaptation: U.S. short day onion production areas. 1998.

Jucar (XP 15238) - Breeder and vendor: Seminis Vegetable Seeds-Asgrow. Parentage: F1 hybrid. Characteristics: long day Spanish onion; mid-late maturity; Recas type; very large bulbs; high yield; dark colored scales; good for ringing; storability is better than Grano Oro. Resistance: Fusarium basal rot. Similar: Daytona. Adaptation: Chile. 2002.

Kiyotaki-Breeder and vendor: American Takii, Inc. Characteristics: medium-early, single-stalk; upright plant habit; bunching onion; high tolerance to cold temperatures; ideal fall-to-winter crop. 2005.

Leona (XP 07595003) - Breeder and vendor: Seminis Vegetable Seeds. Parentage: F1 hybrid. Characteristics: very early maturing with high bolting tolerance; large, globe shaped bulbs; thin, mediumdark bulb scales; glossy foliage; thin necks; firm bulbs that ship well; for planting in mid to late fall in latitudes between $25^{\circ}$ and $35^{\circ}$; also for late short day type at lower latitudes. Resistance: pink root. Similar: Cimarron. Adaptation: NAFTA-Texas, New Mexico, northern California. 2005.

Mackenzie (XP 07715682)—Breeder and vendor: Seminis. Parentage: Hybrid. Characteristics: long day yellow hybrid onion; early maturing; storage type; uniform size; high globe shape; good color; bolt tolerant; very firm with tight necks; suited for long term storage; diameter about $7 \mathrm{~cm}$; weight 180-200 g per bulb. Similar: Frontier. Resistance: Fusarium basal rot (FBR). Adaptation: NAFTA-Northeast U.S. 2005.

Milestone-Breeder and vendor: American Takii, Inc. Characteristics: early maturing (105-110 days), long-day variety; large, hard, yellow Spanish-type with high percentage of single centers; uniform shape with nice brown skin color and thin necks. Adaptation: fresh, processing, and export markets. 2005.

Monarchos (XP 07715843) - Breeder and vendor: Seminis. Parentage: hybrid. Characteristics: hybrid yellow long day onion with bronze skin and high single centers; mid-season maturity (120 days), good scale cover for mechanical harvest; bolt tolerant; high percentage of single centers; average field yield; good size grading. Similar: Ranchero, Santa Fe. Resistance: Fusarium basal rot. Adaptation: NAFTA-Northwest. 2005.

Mr. Buck-Breeder and vendor: D. Palmer Seed, Co., Inc. Characteristics: sweet Vidalia type; this hybrid onion has a deep, flat shape with wide rings; matures in late mid-season and produces a high percentage of jumbo sizes. 2002.

Nebula-Breeder and vendor: Stokes Seeds, Inc. Characteristics: large uniform dark-brown, globe-shape bulb that provides exceptional high quality pack; medium-long; this variety has 6- to 8-month storage possibilities and is well suited for mechanical harvesting; plants have outstanding vigor and strong root system. Resistance: tolerant to Fusarium and pink rot. 2005

Orizaba (XP 07715646) - Breeder and vendor: Seminis. Characteristics: long day white onion for the early season segment; good scale cover; bolt tolerant; spring planted/transplanted; late summer/ early fall harvest; grown at latitudes lower than $48^{\circ}$. Similar: Cometa and Blanco de Oro. Resistance: None. Adaptation: NAFTA-Mexico and Pacific Northwest. 2005.

Pathfinder-Breeder and vendor: Rio Colorado Seeds. Characteristics: long-day onion; great storage characteristics; shiny copper skin is firm and attractive; high yielding and widely adapted. Resistance: excellent tolerance to bolting and pink root. 1998.

Perez (XP 07905013) - Breeder and vendor: Seminis. Parentage: F1 hybrid. Characteristics: golden brown export type, mid-day storage type with very good storability ( 5 months); shape is round, tops are vigorous, uniformity is excellent. Resistance: Fusarium basal rot. Similar: Kiwi Gold. Adaptation: NAFTA-Northeast and Northwest U.S. 2005.

Predator-Breeder and vendor: Rio Colorado. Characteristics: features adaptability, an attractive appearance, and high yield potential that have made it popular in all major growing areas; has blue green foliage and large to jumbo sized bulbs. 1998.

Redwing-Breeder and vendor: Bejo Seeds. Characteristics: dark red long-day storage onion with thick skin; very hard onion; has good color throughout and produces large globes up to $31 / 2$ inches. 1998

Seahawk (EX 15232) - Breeder and vendor: Seminis Vegetable Seeds-Asgrow. Parentage: F1 hybrid. Characteristics: Spanish, storage type; dark skinned; sizes well; will store up to 7 months; 110 day maturity. Resistance: intermediate to Fusarium basal rot and pink root. Similar: Valiant. Adaptation: NAFTA, Pacific northwest U.S. 2003.

Sevillana (129013) - Breeder and vendor: Seminis Vegetable Seeds-Petoseed. Parentage: F1 hybrid. Characteristics: mid season long day type with high plant vigor; gives larger sizes under low plant density and mid sizes (very uniform) under high plant density; skin is good dark color; storability good. Similar: Daytona. Adaptation: South America. 2003.

SM 107-Breeder and vendor: Samen Mauser America. Parentage: hybrid. Characteristics: Granex hybrid; very early maturing; slow bolting and uniform medium to large onion has flattened globes with refined necks; diameter measures $31 / 2$ to 4 inches. Resistance: tolerance to pink root and Botrytis. 1998.

SMX 102-Breeder and vendor: Samen Mauser America. Parentage: hybrid. Characteristics: short-day hybrid Grano type onion; features crisp, firm, and mild flesh with extreme vigor; high yielding; slow bolting. Resistance: pink root tolerance. 1998.

Tara-Breeder and vendor: Rio Colorado. Characteristics: intermediate onion; has been adapted to withstand the stresses of heat and dry conditions; yields mostly jumbo to colossal sized onions. Resistance: bulbs have excellent pink root resistance. 1998.

Toluca (XP 07777103) - Breeder and vendor: Seminis. Parentage: Hybrid. Characteristics: full season white Spanish long day onion, matures in 120 days with shiny white globe shaped bulbs; sprint planted/transplanted; late summer/early fall harvest; grown at latitudes lower than $48^{\circ}$. Similar: Sterling. Resistance: Intermediate resistance to Fusarium basal rot (FBR). Adaptation: NAFTAMexico and Pacific Northwest. 2005.

XON 301W-Breeder and vendor: Sakata Seed America, Inc. Parentage: Hybrid. Characteristics: new intermediate hybrid white onion with a consistent globe shape and brilliant white scale; typically jumbo in size; mid-early maturity; offers a high percentage of single-centered onions. Resistance: tolerant to pink root. 2005. 


\section{PEA-GREEN}

Ashton (XP 08500566) - Breeder and vendor: Seminis Vegetable Seeds-Asgrow. Parentage: open pollinated. Characteristics: full season Dark Large Wrinkled (DLW) type; normal foliage; good determinate plant type combined with good reliability and quality of the frozen product; first flowering node: 14; sieve size distribution at 105 tenderometer of the whole sample: $10 \%<8.2 \mathrm{~mm}, 10 \% 8.2$ $8.75 \mathrm{~mm}, 25 \% 8.75-9.2 \mathrm{~mm}, 35 \% 9.2-10.3 \mathrm{~mm}, 20 \%>10.3 \mathrm{~mm}$. Resistance: bean yellow mosaic virus, powdery mildew, Fusarium wilt (race 1), downy mildew. Similar: Bolero, Durango. Adaptation: NAFTA. PVP application \#200300003. 2003.

FR341 - Breeder and vendor: Brotherton Seed Co. Characteristics: combines exceptional color and eating quality with high yield, great standability, and ease of harvest; second-early processing pea. Resistance: resistant to wilt and nearwilt. 1998.

Icebreaker (XP 8504158) - Vendor: Seminis Vegetable SeedsAsgrow. Parentage: open pollinated. Characteristics: early maturing (heat units: $624^{\circ} \mathrm{C}, 1155^{\circ} \mathrm{F}$ ); first blooming node is 9 to 10 ; same maturity as Cabree; leafless (afila) type; low starch content (AIS); 1 to 2 pods per node; pods have blunt tip and 7 to 8 berries; sieve size $2.9(8.65 \mathrm{~mm})$ at 100 tenderometer; vine is $40 \mathrm{~cm}$ long. Resistance: Fusarium wilt race 1. Similar: Cabree, Spring. Adaptation: NAFTA, processing. PVP application \#200200196. 2002.

Jesse - Breeder and vendor: Brotherton Seed Co. Characteristics: a determinate stringless snap pea suitable for mechanical harvest and freezing; has a dark, smooth, sweet pod. Resistance: wilt and powdery mildew. 1998.

Oregon Sugar Pod III (RS 08790490)-Breeder and vendor: Seminis Vegetable Seeds. Parentage: open pollinated. Characteristics: normal leaf type; plants $95 \mathrm{~cm}$ tall; pods are mid-green colored, blunt-tipped, $95 \times 24 \mathrm{~mm}$ size; first pods at node 14, usually 2 pods per node, each with 8 smooth seeds. Resistance: Fusarium wilt (race 1); intermediate to powdery mildew. Similar: Green Goliath. Adaptation: NAFTA. 2005

Pendleton (XP 08510597)—Breeder and vendor: Seminis. Parentage: open pollinated. Characteristics: dark green, large wrinkled full season afila that first flowers at the 14th node; matures at 790 heat units $\left({ }^{\circ} \mathrm{C}\right)$ with an average sieve size of 3.1 at 100 tenderometer. Resistance: Fusarium wilt races 1-2, powdery mildew; intermediate to Bean leaf roll. Similar: Genie, Aladdin, Bolero. Adaptation: NAFTAfor processing. 2005.

Sherwood (XP 08500564) - Breeder and vendor: Seminis Vegetable Seeds-Asgrow. Parentage: open pollinated. Characteristics: early Dark Green Large Wrinkled (DLW) pea type with a normal plant type; sieve size distribution measured at tendrometer 105: $<8.25 \mathrm{~mm}$ : 10\%; 8.25-8.75 mm: 15\%; 8.75-9.25 mm: 30\%; 9.25-10.25 mm: $30 \%$; > $10.25 \mathrm{~mm}: 15 \%$; average sieve size $=3.25$ ); first flowering node: 9. Resistance: bean yellow mosaic virus, downy mildew, Fusarium wilt (race 1). Similar: Spring. Adaptation: NAFTA. 2003.

Solution (XP 8504178) - Breeder and vendor: Seminis Vegetable Seeds-Asgrow. Parentage: open pollinated. Characteristics: early full season afila type with medium large sieve size; pod has blunt tip; 8-9 berries per pod; vine is about $55 \mathrm{~cm}$ long; good color and quality on a short, productive plant. Resistance: Fusarium wilt races 1, 2, bean yellow mosaic virus strain pea. Similar: Aladdin, Ripon. Adaptation: North America. PVP Pending \#200200028. 2001.

Survivor (XP 8504198) — Breeder and vendor: Seminis Vegetable Seeds-Asgrow. Parentage: open pollinated. Characteristics: late season, short vine afila with excellent yield potential and consistency, resistance to multiple races of Fusarium wilt, dark green large wrinkled seeds. Resistance: Fusarium wilt races 1, 2, 5, 6. Similar: Genie, Lazor. Adaptation: processor, North America. 2002.

Sweet Ann (XP 08590485) - Breeder and vendor: Seminis Vegetable Seeds-Asgrow. Parentage: open pollinated. Characteristics: sweet, smooth, stringless pods of 70-75 mm in length, 11-12 mm breadth, about $5 \mathrm{~mm}$ of curvature with pointed ends, mid season maturity, first blooms at the $14-15$ th node; medium green, shiny pods are uniformly set on a short plant that is well suited for mechanical harvest (with a bean harvester). Resistance: downy mildew, powdery mildew, Fusarium wilt (race 1), bean yellow mosaic virus. Similar: Sugar Sprint, Sugar Prince. Adaptation: NAFTA. 2003.

Trilogy (XP 22096) - Breeder and vendor: Seminis Vegetable Seeds-Asgrow. Parentage: open pollinated. Characteristics: late maturity; normal foliage; large sieve size; freezer type; medium vine length; high yield. Resistance: Fusarium wilt race 1, powdery mildew, pea enation mosaic virus. Similar: Valverde. Adaptation: processor mid-Atlantic states U.S., Italy and Spain. 2002.

\section{PEPPER}

Aci Sivri-Vendor: Seeds of Change. Characteristics: openpollinated, old Turkish cultivar, can be mild to very hot; very productive, producing up to fifty $127-78 \times 19 \mathrm{~mm}$ fruits, matures in 90 days. Adaptation: wide.

Admiral-Vendor: Roger's Brand. Characteristics: $\mathrm{F}_{1}$ hybrid bell pepper, green maturing to yellow, mostly 4-lobed, blocky, extra large, medium tall, vigorous plants providing excellent cover. Resistance: Tobacco Mosaic Virus, Potato Virus Y, Bacterial Leaf Spot races 1 and 2, tolerance to Stip. Adaptation: All production areas.

Affinity (RFT 8532) - Breeder and vendor: Syngenta Seeds, Inc/ Rogers Brand. Characteristics: medium-dark-green, glossy, blocky bell pepper that has produced four-lobed fruit with thick walls; trialed in the Central Valley of California, this variety demonstrates outstanding fruit quality while producing high yields of extra-large and large fruit. 2005.Alliance (HMX 2643) - Breeder and vendor: Harris Moran. Parentage: F1 hybrid. Characteristics: sweet pepper; extra large fruit are block with green to red color. Resistance: cucumber mosaic virus; pepper mottle virus; potato virus Y races 0 , 1, 1-2; Xanthomonas vesicatoria races 1, 2, 3, 4, 5; Phytophthora capsici. Adaptation: U.S. 2003.

Amos (HA-1589) - Vendor: Hazera Quality Seed. Characteristics: $F_{1}$ hybrid bell pepper, green maturing to red, $90 \times 80 \mathrm{~mm}$, medium fruit walls, 4 lobes in fruit, pendent, medium earliness. Best for greenhouse and net production. Resistance: Tobacco Mosaic Virus pathotype 0, Potato Virus Y.

Ancho Allende (SSC 1326) - Breeder: Magnum Seeds. Vendor: Shamrock Seed Co. Parentage: F1 hybrid. Characteristics: medium to tall, vigorous bush; concentrated set of very uniform fruit; fruit has excellent size, shape and dark color; average fruit size is $2 \times 6$ inches; shallow shoulders; good level of pungency for this type of pepper. Similar: Caballero, Ancho Real. Adaptation: all pepper production areas. 2005.

Ancho Arriero (HMX 2673) - Breeder and vendor: Harris Moran. Parentage: F1 hybrid. Characteristics: hot pepper; Ancho type; large dark green fruit for fresh market. Adaptation: U.S. 2003

Ancho Real (HMX 1673) - Breeder and vendor: Harris Moran Parentage: F1 hybrid. Characteristics: hot pepper; mainly 2-lobed, flat dark green, very pungent fruit. Adaptation: U.S. 2003.

Andy-Vendor: Johnny's Selected Seeds. Characteristics: $F_{1}$ hybrid New Mexican type, 60 days to green, 85 days red ripe, $20 \times 190 \mathrm{~mm}$ fruit size, a strong erect plant frame holds fruit up well so they grow long and straight. Resistance: Tobacco Mosaic Virus.

Antillais Caribbean-Vendor: Technisem. Characteristics: Open-pollinated scotch bonnet type, light green maturing to light red, $55 \times 45 \mathrm{~mm}$ fruit size, globular lantern shape, very pungent, open plant habit, $800 \mathrm{~mm}$ tall.

Antonio (FAR-3) - Vendor: Hazera Quality Seed. Characteristics: $F_{1}$ hybrid Lamuyo type bell pepper, green maturing to red, $160 \times 80 \mathrm{~mm}$, large elongated fruit, thick fruit walls, 3-lobed, pendent, spreading plant habit. Adaptation: Greenhouse and tunnel production.

Aquiles (PS 11410851) —Breeder and vendor: Seminis Vegetable Seeds. Parentage: F1 hybrid. Characteristics: jalapeno type; strong plant; continuous fruit setting ability; very large fruit are uniform in size; fruit are dark green, smooth and have a thick wall; fruit are $109 \times 39 \mathrm{~mm}$ size and have hot pungency. Similar: Conchos, El Rey. Adaptation: NAFTA-Mexico, fresh market. 2005. 
Arika-Vendor: Technisem. Characteristics. $\mathrm{F}_{1}$ hybrid Lamuyo bell pepper type, dark green maturing to vivid red, $80 \times 130 \mathrm{~mm}$ fruit size, 4-lobes, semi-concentrated fruit set, pendant fruits, plant is $900 \mathrm{~mm}$ tall. Resistance: Potato Virus Y, Tobacco Mosaic Virus.

Aurora-Vendor: Seed Saver's Exchange. Characteristics: Open-pollinated ornamental, tapered fruit, $38 \mathrm{~mm}$ long fruit, upright, ripens from lavendor to deep purple to orange and finally to red, medium pungency, 250-305 mm tall, purple and green foliage,

Autlan (SSC 1459) - Breeder and vendor: Shamrock Seed Co. Characteristics: very hot, early maturing Jalapeno type with concentrated set; medium-tall plants with broad, dark green leaves that provide good cover; short internodes to ensure excellent fruit set; produces and maintains large ( 3 to 3.75 inches $\times 1$ to 1.25 inches) fruit through several harvests; dark green fruit with thick walls and a large center with 3 to 4 locules; no anthocyanin and low incidence of checking at maturity; relative maturity 75 to 85 days from transplant. Similar: Jalapeno M. Adaptation: all pepper growing regions. 2004.

Autopick-Breeder: F.C. Elliott and N. A. Elliott. Characteristics: Open pollinated jalapeno adapted for machine harvest. Fruit ripens from light green (Munsell 5GY) to red (Munsell 7.5R 5/6) PVP 9500317. 1999.

Balo-Vendor: Rijk Zwaan. Characteristics: $F_{1}$ hybrid Dolma type bell pepper, early, nicely-shaped fruits with good shelf life, thin fruit walls. Resistance: Tobacco Mosaic Virus pathotypes 0, 1, 2.

Bandido (HMX 1675) - Breeder and vendor: Harris Moran. Parentage: $F_{1}$ hybrid. Characteristics: hot pepper; Serrano hot pepper type; very dark green fruit; medium size plant. Adaptation: California, Mexico. 2003.

Beauty Zest-Vendor: Known-You Seeds. Characteristics: $\mathrm{F}_{1}$ hybrid, Asian hot type, $150 \times 15 \mathrm{~mm}$ fruit size, very pungent, spreading plants, well-branched with short internodes, very productive. Resistance: Tobacco Mosaic Virus.

Beefsteak-Vendor: Burpee. Characteristics: $F_{1}$ hybrid, tomato/ cheese type pepper, 83 days to maturity, sweet pepper when picked red, very prolific.

Beitar (HA-817) — Vendor: Hazera Quality Seed. Characteristics: $F_{1}$ hybrid Lamuyo bell pepper type, green maturing to red, $140 \times 80 \mathrm{~mm}$ fruit size, large elongated fruit, medium thick fruit walls, 3-lobed, pendant, medium spreading plant habit. Resistance: Potato Virus Y, Tobacco Mosaic Virus pathotype 0. Adaptation: Open field production.

Bengal (HA-905) - Vendor: Hazera Quality Seed. Characteristics: $F_{1}$ hybrid Marconi type, green maturing to red, $170 \times 80 \mathrm{~mm}$ fruit size, thin fruit walls, 2-lobed, pendant, tall upright plant habit. Resistance: Tobacco Mosaic Virus 0. Adaptation: Open field and tunnel production.

Big Banana-Vendor: Thompson and Morgan. Characteristics: $F_{1}$ hybrid banana or Hungarian wax type, sweet, matures in 95 days, fruits size is $254 \times 102 \mathrm{~mm}$, yellow maturing to a deep shiny scarlet, up to 50 full-sized fruits per plant.

Big Bomb (PS 11410193)-Breeder and vendor: Seminis. Parentage: F1 hybrid. Characteristics: green to red hot cherry pepper for pickling, fruit $5 \mathrm{~cm}$ wide by $5 \mathrm{~cm}$ long, globular to pointy fruit shape, dark green turning to bright red at maturity. Similar: Grandi. Adaptation: NAFTA-Eastern United States Processors; Northwest and Southwest U.S. for home garden. 2005.

Big Sun-Vendor: Technisem. Characteristics: Open-pollinated scotch bonnet type, globular wrinkled shape, dark green to maturing to vivid yellow, $55 \times 50 \mathrm{~mm}$ fruit size, very pungent, 100 days, open plant habit, $800 \mathrm{~mm}$ tall. Adaptation: Tropical areas.

Biltmore - Breeder and vendor: Stokes Seeds, Inc. Characteristics: main season variety; extra-large, 10-oz, high-quality fruit; very firm; good crack tolerance; semi-determinate; suited for row crops or basket weave culture. Resistance: tolerant to alternaria stem canker, Fusarium wilt race 1 and 2, grey leaf spot, and Verticillium wilt race 1. 2005.

Blast-Breeder: Marlin Edwards. Vendor: Syngenta. Characteristics: Ornamental pepper, 8-10 fruit clusters on top of plant, 4-6 fruits per cluster, fruit is ivory to yellow to vivid red, fruit is $25 \times 19 \mathrm{~mm}$, plant is $127 \mathrm{~mm}$ tall and $152-203 \mathrm{~mm}$ wide. Adaptation: Best suited for 4-inch pots. PVP 200100028
Black Hungarian-Vendor: Seed Savers Exchange. Characteristics: Open-pollinated ornamental, green foliage is highlighted by purple veins, purple flowers, sturdy plants, grow 762 to $914 \mathrm{~mm}$ tall, 76 to $102 \mathrm{~mm}$ fruit size, similar to a jalapeno shape, black ripening to red, mildly hot with good flavor.

Burkina Yellow-Vendor: Technisem. Characteristics: Openpollinated scotch bonnet type, globular wrinkled, elongated pointed end fruits, very light green to yellow-red at maturity in 90-120 days, very hot, plant size is 500-700 mm. Resistance: Powdery Mildew.

Caloro-Breeder: Paul G. Smith. Vendor: Plants of the Southwest. Characteristics: Open-pollinated yellow wax type, pungent, fruit matures from yellow to orange-red, $89 \times 38 \mathrm{~mm}$ fruit size, medium-thick walls, medium-sized upright plant provides good cover and has a pendant fruiting habit with continuous setting, very prolific. Resistance: Tobacco Mosaic Virus pathotype 0. Similar: Santa Fe Grande. Adaptation: Wide.

Candybar-Vendor: Gurney's Seed and Nursery Co. Characteristics: Open-pollinated, green to reddish brown colored bell pepper, elongated, three-lobed bell, sweet, blocky $102 \times 102 \mathrm{~mm}$ size, 82 days to maturity.

Capela-Vendor: Technisem. Characteristics: Open-pollinated bell pepper type, medium green maturing to dark red, green fruit in 60-65 days, concentrated fruit set, pendant, $100 \times 75 \mathrm{~mm}$ fruit size, 3-4 lobed, compact plants are 450-600 mm tall. Resistance: Heat, Potato Virus Y, Tobacco Mosaic Virus, Powdery Mildew.

Chain Fair-Vendor: Known-You Seeds. Characteristics: $F_{1}$ hybrid, Asian hot type, tall vigorous plants, fruit 170-200×16 mm, very hot, with smooth skin surface.

Chapala (PS 11404682) - Breeder and vendor: Seminis Vegetable Seeds. Parentage: F1 hybrid. Characteristics: Jalapeno fresh market type; large fruit size; dark green color; high yield; not sensitive to cold nights. Similar: El Rey. Adaptation: NAFTAMexico. 2004.

Charleston Belle-Breeder: USDA Agricultural Research Services Vegetable Laboratory. Vendor: Territorial Seed Company. Characteristics: Open-pollinated green maturing to red bell pepper, 85 days, sweet, $89 \times 76 \mathrm{~mm}$ fruit size. Resistance: Root-knot nematode. Adaptation: Southeast U.S.

Charleston Hot-Breeder: USDA Agricultural Research Services Vegetable Laboratory. Vendor: R.H. Shumway's. Characteristics: Open-pollinated, cayenne type, very hot, high yielding, vigorous, fruit straight to slightly curved, matures from yellow-green to golden yellow to brilliant orange, to a deep red, $457 \mathrm{~mm}$ tall plants. Resistance: Southern root-knot nematode. Adaptation: Southeast U.S.

Cherry Pick-Vendor: R.H. Shumway's. Characteristics: $F_{1}$ hybrid cherry type, sweet, dark green mature to red, $32 \times 32 \mathrm{~mm}$ fruit size, uniformly, rounded fruit, high yielding plants.

Chianti (HMX 1663) - Breeder and vendor: Harris Moran. Parentage: F1 hybrid. Characteristics: sweet pepper; large, rectangular, half-long fruit, deep red color. Resistance: BLS 1, 2, 3; PVY, PeMV and TMCV (PO). Adaptation: U.S. 2003.Chilancho-Vendor: Stokes. Characteristics: $F_{1}$ hybrid Ancho/Poblano type, dark green matures to dark red, fruit is $152 \mathrm{~mm}$ deep, wide shouldered, high yields.

Chichimeca (PS 11404634) — Breeder and vendor: Seminis Vegetable Seeds. Parentage: F1 hybrid. Characteristics: Jalapeno type; large fruit size, $103 \times 40 \mathrm{~mm} ; 36 \mathrm{~g}$ fruit weight; concentrated fruit set; pungent; early maturity. Similar: Conchos. Adaptation: NAFTA-Mexico. 2004.

Chilly Chili-Breeder: Marvin Edwards. Vendor: PanAmerican Seeds. Characteristics: Fruit is non-pungent, $50 \mathrm{~mm}$ in length, matures from yellow to orange to red, extremely heat tolerant, plants are $305 \mathrm{~mm}$ tall and 152-250 $\mathrm{mm}$ wide. 2002 All-American Selection winner.

Cipalas-Vendor: Technisem. Characteristics: Open-pollinated Asian hot type, dark green maturing to red, long slim curled pointed end fruits, $100 \times 7 \mathrm{~mm}$, green fruit mature in 65-75 days, vigorous upright plant.

Colossal-Vendor: Roger's Brand. Characteristics: $F_{1}$ hybrid medium-dark green maturing to red bell pepper, blocky, extra large, medium tall, upright vigorous plants. Adaptation: Georgia, Midwest, and Northeast. 2005. 
Comanche (HA-1134) — Vendor: Hazera Quality Seed. Characteristics: $F_{1}$ hybrid Lamuyo bell pepper type, gold color, $140 \times 80 \mathrm{~mm}$, large elongated fruit, thin fruit walls, 3-lobed, pendant, tall upright plant habit. Resistance: Potato Virus Y, Tobacco Mosaic Virus 0. Adaptation: Under net covering.

Consul-Vendor: Harris-Moran. Characteristics: $\mathrm{F}_{1}$ hybrid bell pepper, green maturing to red, blocky, $110 \times 110 \mathrm{~mm}$ fruit size, glossy, thick walls, plant vigorous, tall with good foliage cover, 65 days to maturity. Resistance: Cucumber Mosaic Virus, Pepper Mottle Virus, Potato Virus Y, Tobacco Mosaic Virus, and Phytophthora. Adaptation: Mexico and U.S. growing regions.

Corcel (PS 11410078) — Breeder and vendor: Seminis Vegetable Seeds. Parentage: F1 hybrid. Characteristics: Ancho type; fruit $17.5 \mathrm{~cm} \times 9 \mathrm{~cm}$, high percentage of two locule fruit, dark green color turning chocolate in the ripe stage; strong plant, specific use is fresh market; not for drying at the red stage. Similar: Caballero, Ancho San Juan, Tiburon. Adaptation: NAFTA-Mexico. 2004.

Crusader-Vendor: Roger's Brand. Characteristics: $F_{1}$ hybrid bell pepper, dark green maturing to red, blocky, thick walls, sturdy upright plants, large leaf offers good fruit covering. Resistance: Bacterial leaf spot races 1, 2, and 3, Tobacco Mosaic Virus, Pepper Mottle Virus, Potato Virus Y, tolerance to Stip. Adaptation: All planting seasons in southeast U.S. 2005.

Cyklon-Vendor: Seed Savers Exchange. Characteristics: Openpollinated hot pepper from Poland, thin walls, fruit matures to red, slightly curved, $50 \times 114 \mathrm{~mm}$ fruit size.

DMC 58-214-Vendor: Del Monte Corp. Characteristics: Open pollinated jalapeno, $710 \mathrm{~mm}$ plant height, easy destemming ability, matures in 145 days from direct seeding. PVP 9600206. 1996.

Don Juan (HMX 4659) - Breeder and vendor: Harris Moran. Parentage: F1 hybrid. Characteristics: hot pepper; Jalapeno type; large dark green fruit for fresh market and processing. Adaptation: U.S. 2003.

Double Up - Breeder and Vendor: Sakata Seed. Characteristics: $F_{1}$ hybrid bell pepper, medium-large, green maturing to uniform bright red, 4-lobed, blocky, very little purpling, mid-early maturity, concentrated fruit set. Resistance: Bacterial leaf spot races 1, 2, and 3. Adaptation: Wide. 2005.

El Charro (HA-1038) - Vendor: Hazera Quality Seed. Characteristics: $F_{1}$ hybrid bell pepper, green maturing to red, $110 \times 80 \mathrm{~mm}$, medium fruit walls, 3-4 lobed, pendant. Resistance: Potato Virus Y, Tobacco Mosaic Virus pathotype 0. Adaptation: Open field and under net covering production.

El Jefe-Breeder and vendor: Siegers Seed Company. Characteristics: high-quality jalapenos that are darker green with thicker walls, smaller cavity, and more cylindrical shape; high yields. Resistance: bacterial spot races 1,2, and 3. Adaptation: widely adapted; ideal for both fresh and processing markets. 2005.

Ember-Breeder: Marlin Edwards. Vendor: Syngenta. Characteristics: Ornamental, conical fruit $25 \times 13 \mathrm{~mm}$, purple foliage and flowers, fruit ripens from purple to deep red, plant is $250-356 \mathrm{~mm}$ tall and 203-250 mm wide. Adaptation: Performs well in jumbo pack, 6-inch pots with 3 plants per pot. PVP 200100029

Emerald Isle-Vendor: Harris Moran. Characteristics: $F_{1}$ hybrid elongated bell pepper, green maturing to red, blocky, 3-lobed, $130 \times 90 \mathrm{~mm}$ fruit size, glossy, thick walls, plant vigorous, intermediate height with good foliage cover. Resistance: Cucumber Mosaic Virus, Potato Virus Y, and Phytophthora. Adaptation: Open field production.

Encore - Vendor: Roger's Brand. Characteristics: $F_{1}$ hybrid bell pepper, green maturing to red, blocky, very smooth, thick walls, medium high plants, very good foliage cover. Resistance: Pepper Mottle Virus, Potato Virus Y, tolerance to Stip. Adaptation: California and West Mexico production areas.

Ethem-Breeder and vendor: Stokes Seeds, Inc. Characteristics: early sweet banana pepper matures with Super Sweet Banana with very high yields; jumbo fruits are about 8 inches long with a refined shoulder; ripens lime green, yellow, and red. 2005.

Ever-Flavor-Vendor: Known-You Seeds. Characteristics: $F_{1}$ hybrid, Asian hot type, spreading plants, branched, vigorous, prolific, $150 \times 12 \mathrm{~mm}$ fruit size, very hot, pendant.
Excursion II-Breeder and vendor: Abbott \& Cobb Inc. Characteristics: very dark green, uniform blocky bell pepper with thick walls and very strong crown set. Resistance: bacterial leaf spot races 1,2 , and 3, tomato mosaic virus, tomato spotted wilt virus, potato virus Y. Adaptation: Florida and Georgia. 2005.

Fatalii-Vendor: Pepper Joe's, Inc. Characteristics: Openpollinated Capsicum chinense pod type, originally from Central Africa, light green maturing to bright yellow, distinctly pointed end.

Filabri (HA-1860) - Vendor: Hazera Quality Seed. Characteristics: $F_{1}$ hybrid New Mexican type, dark green maturing to red, $150 \times 40 \mathrm{~mm}$ fruit size, medium thick fruit walls, 3-lobed, pendant. Adaptation: Open field production. Resistance: Potato Virus Y, Tobacco Mosaic Virus pathotype 0.

Fish-Vendor: Seed Savers Exchange. Characteristics: Openpollinated African-American heirloom ornamental type, green and white foliage, fruit is $64 \mathrm{~mm}$ long, pendant, ripens from cream with green stripes to orange with brown stripes to all red.

Flush (HA-506) - Vendor: Hazera Quality Seeds. Characteristics: $F_{1}$ hybrid tomato (Gambo) type, green maturing to red, 4-5 lobes, very thick fruit walls, $50 \times 100 \mathrm{~mm}$ fruit size, pendent fruit, tall plant habit. Resistance: Tobacco Mosaic Virus and Potato Virus Y. Adaptation: Open field production.

Fluorescent Purple-Vendor: Pepper Joe's, Inc. Characteristics: Open-pollinated heirloom cultivar, leaves are a sensational fluorescent purple and white, fruit are green, to purple, then to red when ripe, very pungent.

Fruit Basket-Vendor: Park Seed Co. Characteristics: $F_{1}$ hybrid squash type, green maturing to orange, sweet, $127 \mathrm{~mm}$ sized fruit, plants are adapted to hanging basket, plant is $250 \mathrm{~mm}$ high and $610 \mathrm{~mm}$ wide.

Goliath-Vendor: R.H. Shumway's. Characteristics: $F_{1}$ hybrid bell pepper, green to dark red, 4-lobed, $102 \times 178 \mathrm{~mm}$ fruit size, elongated, thick-walled fruits, vigorous plant habit. Adaptation: Wide. Greygo-Breeder and vendor: Meyer Seed International. Characteristics: large, flattened, early maturing, pendant, broadshouldered cherry pepper; $21 / 4$ inches across by $11 / 4$ inches deep; matures from green to a brilliant deep red; has excellent eating and processing qualities. 2005.

Group Zest-Vendor: Known-You Seeds. Characteristics: $F_{1}$ hybrid, Asian hot type, medium-tall, spreading plants, very earlymaturing with concentrated harvest, $160 \times 20 \mathrm{~mm}$ fruit size, thick flesh with strong pungency.

Guantanamo-Vendor: Stokes. Characteristics: $F_{1}$ hybrid Cubanelle type, lime green maturing to red, smooth, 2-3 lobed, $185 \mathrm{~mm}$ long fruit, tapered to blunt tip, very sweet.

Guardian-Vendor: Roger's Brand. Characteristics: $F_{1}$ hybrid bell pepper, very dark green maturing to red, 4-lobed, deep blocky, firm, and smooth, plant is moderately strong, vigorous, and upright. Resistance: Potato Virus Y, Tobacco Etch Virus, Tobacco Mosaic Virus, Bacterial Leaf Spot races 1 and 2. Adaptation: Central and Coastal California and desert southwest.

HA 1038 - Breeder and vendor: Hazera Quality Seeds. Characteristics: produces blocky type, very firm green or red fruit; great shelflife and shipability. Resistance: TMO and PVY. 1998.

Heritage VR - Breeder and vendor: Harris Moran. Parentage: F1 hybrid. Characteristics: blocky shape; green to red color. Resistance: BLS races 1, 2, 3, 5; highly tolerant to TSWV. Adaptation: Florida, Georgia, South Carolina and North Carolina, U.S. 2002.

Home Flavor-Vendor: Known-You Seeds. Characteristics: $F_{1}$ hybrid, Asian hot type, straight fruit, $160 \times 15 \mathrm{~mm}$ fruit size, medium-tall plants, spreading with dark green leaves. Resistance: Tobacco Mosaic Virus.

Honeybelle - Vendor: Harris Seeds. Characteristics: $F_{1}$ hybrid Lamuyo type bell pepper, dark green maturing to golden yellow, elongated, 3-4 lobed, thick walls, vigorous plant habit.

Hungarian Spice Hybrid-Vendor: Park Seed Co. Characteristics: $F_{1}$ hybrid New Mexican type, green maturing to dark red, mildly spicy, thin-walled, $178 \mathrm{~mm}$ fruit size.

Ignite-Breeder: Marlin Edwards. Vendor: Syngenta. Characteristics: Ornamental, long narrow fruit, $25 \times 3 \mathrm{~mm}$ fruit size, fruit 
ripens from ivory-white to green yellow to orange red, green foliage with thin leaf shape, spreading habit, slightly mounded, plant is 76-127 $\mathrm{mm}$ tall and 305-356 mm wide. Adaptation: Hanging baskets, and 4- to 6-inch pots when 3 plants per pot. PVP 200100030

Independence (HMX 1661)-Breeder and vendor: Harris Moran. Parentage: F1 hybrid. Characteristics: sweet pepper; extra large, slightly elongated blocky fruit; exceptional deep red color; early set. Resistance: BLS 1,2,3,5. Adaptation: U.S. 2003.

Indra-Vendor: Roger's Brand. Characteristics: $\mathrm{F}_{1}$ hybrid bell pepper, medium green maturing to red, 3-4 lobed, blocky, firm, and smooth, plant is compact, strong, vigorous with a broad dense canopy providing excellent coverage. Resistance: Potato Virus Y, Tobacco Etch Virus, Tobacco Mosaic Virus. Adaptation: Central and Coastal California and desert southwest.

Italia-Vendor: Johnny's Selected Seeds. Characteristics: Openpollinated Italian frying type, 55 days to green, 75 days to a dark crimson red, $203 \times 64 \mathrm{~mm}$ fruit size, with wide shoulders, sweet. Similar: Corno di Toro.

Ixtapa (PS 9096) - Breeder and vendor: Seminis Vegetable Seeds. Characteristics: Has a vigorous plant, jumbo fruit, and is a dark green fruit with excellent yield potential that is red at maturity and has a Scoville range of 4000 to 6000 . Resistance: Bacterial spot 1, 2, 3 (XR). 2002.

Jaladuro-Breeder: United Genetics. Vendor: Siegers Seed Co. Characteristics: $F_{1}$ hybrid jalapeno, excellent choice for processing, shiny fruits display a longer shelf life, have less tendency to check and wrinkle, early maturity, 89-mm-long fruit.

Jimmy Nardello's - Vendor: Seed Savers Exchange. Characteristics: Open-pollinated Italian cultivar, sweet, extremely productive, plants are $610 \mathrm{~mm}$ high.

Jumbo Stuff - Vendor: Stokes. Characteristics: $F_{1}$ hybrid of Super Stuff, lemon yellow fruits, thick flesh, plants set 8-10 fruit, $150 \times 95 \mathrm{~mm}$ sized fruit. Similar: Super Stuff.

Karma-Breeder and Vendor: Harris Moran. Characteristics: $F_{1}$ hybrid bell pepper, dark green maturing to intense red, blocky, $135 \times 94 \mathrm{~mm}$ fruit size, glossy and thick walls, plant vigorous, tall with good foliage cover, early maturity. Resistance: Tobacco Mosaic Virus. Adaptation: Widely. 1998.

Lady Star-Vendor: Known-You Seeds. Characteristics: $F_{1}$ hybrid, bell pepper, $125 \times 75 \mathrm{~mm}$ fruit size, thick flesh, plants are vigorous and slightly spreading. Resistance: Tobacco Mosaic Virus.

La Rouge Royale - Vendor: Totally Tomatoes. Characteristics: $F_{1}$ hybrid, Lamuyo bell pepper type, green maturing to brilliant red, sweet, very tall plants with plenty of coverage protecting fruits.

Labrador-Vendor: Johnny's Selected Seeds. Characteristics: $F_{1}$ hybrid bell pepper, green maturing to red, medium-large fruit, blocky, sweet, concentrated fruit set, compact plant habit. Resistance: Potato Virus Y, Tobacco Mosaic Virus pathotype 0.

Lafayette-Vendor: Roger's Brand. Characteristics: $F_{1}$ hybrid bell pepper, green maturing to yellow, blocky, uniform fruit, compact plant with good cover. Resistance: Bacterial leaf spot races 1, 2, and 3, Pepper Mottle Virus, Pepper Virus Y. Adaptation: All production areas.

Lantern-Vendor: Johnny's Selected Seeds. Characteristics: $F_{1}$ hybrid bell pepper, dark green maturing to red, large, semi-elongated fruit, 3- to 4-lobed, smooth, and heavy, strong plants have good leaf cover. Resistance: Tobacco Mosaic Virus races 0, 1, 2, and tolerant to stip.

Legionnaire-Vendor: Roger's Brand. Characteristics: $F_{1}$ hybrid bell pepper, medium dark green maturing to red, blocky, thick walls, firm, and smooth. Resistance: Bacterial leaf spot races 1, 2, 3, Tobacco Mosaic Virus, tolerance to Stip. Adaptation: Bush, short stake, or tall stake cultural practices in West Mexico, Florida, Southeast, and Midwest.

Lemon Drop_-Vendor: Seed Savers Exchange. Characteristics: A heirloom Capsicum baccatum cultivar, maturing in 100 days, bright yellow, conical, crinkly fruits, $13 \times 64 \mathrm{~mm}$, hot, citrus flavored.

Liberty (HMX 1664)-Breeder and vendor: Harris Moran. Parentage: F1 hybrid. Characteristics: sweet pepper; large, rectangular, half-long fruit; attractive yellow color. Resistance: BLS 1, 2, 3, 5 and TMV (PO). Adaptation: U.S. 2003.
Lido Lamuyo-Vendor: Totally Tomatoes. Characteristics: Open-pollinated Lamuyo type bell pepper, green maturing to red, $152 \mathrm{~mm}$ long and tapering to $89 \mathrm{~mm}$ wide, very sweet, tall, vigorous plants.

Little Elf-Vendor: Seed Savers Exchange. Characteristics: Open pollinated, ornamental plant, yellow fruits with purple blush ripen to orange then to red, very pungent.

Luigi-Breeder: Seminis Seeds. Vendor: R.H. Shumway's. Characteristics: $F_{1}$ hybrid, Italian roasting type, sweet, up to 45 fruits per plant, $114 \mathrm{~mm}$ long fruit, cylindrical tapered, green maturing to red, plant is $610 \mathrm{~mm}$ tall.

Maccabi (HA-1005) - Vendor: Hazera Quality Seed. Characteristics: $F_{1}$ hybrid Lamuyo bell pepper type, green maturing to red, $160 \times 80 \mathrm{~mm}$ fruit size, large elongated fruit, medium thick fruit walls, 3 lobed, pendant, tall upright plant habit. Resistance: Tobacco Mosaic Virus pathotype 0. Adaptation: Open field and tunnel production.

Maor-Vendor: Hazera Quality Seed. Characteristics: Openpollinated bell pepper, green maturing to red, $100 \times 80 \mathrm{~mm}$ fruit size, blocky, medium thick fruit walls, 3-lobed, pendant. Adaptation: Open field production. Resistance: Tobacco Mosaic Virus pathotype 0 .

Marconi Rosso-Vendor: Burgess Seed and Plant Co. Characteristics: Open-pollinated, sweet, $140 \times 64 \mathrm{~mm}$ fruit size, wide tapering to a blunt point, upright compact plant habit. Similar: Marconi.

Mariachi (227160) - Breeder and vendor: Seminis Vegetable Seeds-Petoseed. Parentage: F1 hybrid. Characteristics: hot pepper; yellow to red; very large size fruit with thick walls, good color, 10.5$11.0 \mathrm{~cm}$ long; wide shoulders are typical so fruit are heavier than Santa Fe Grande; vigorous plant with good set, early maturity. Similar: Santa Fe Grande, Don Nacho. Adaptation: NAFTA. 2003.

Masada (HA 2003) - Breeder and vendor: Hazera Seeds. Characteristics: red Lamuyo pepper; very uniform, thick-walled, heavy fruit with excellent shelf life. Resistance: PVY and TM. 2002.

Master 714-Vendor: Harris Moran Seed. Characteristics: Open-pollinated Marconi type, dark green maturing to red, large blocky, firm, heavy walls, mostly 4-lobed, $152 \times 51 \mathrm{~mm}$ fruit size, $500-635 \mathrm{~mm}$ plant height. Similar: Marconi type peppers.

Medusa-Breeder: Marlin Edwards. Vendor: PanAmerican Seeds. Characteristics: Ornamental, narrow, twisted, snake-like fruits, ivory, yellow, orange and bright red, pointed, 50-55 mm fruit size, 40 to 50 fruits on plant at same time, compact plant habit. PVP 200000140.

Mexibell-Vendor: R.H. Shumway's. Characteristics: $F_{1}$ hybrid bell pepper, green maturing to red, 3-lobed, mild pungency, plant is $660 \mathrm{~mm}$ tall. Resistance: Tobacco Mosaic Virus.

Miles Flavor-Vendor: Known-You Seeds. Characteristics: $F_{1}$ hybrid Asian hot type, uniform, smooth fruit, $145 \times 14 \mathrm{~mm}$ fruit size, prolific with about 200 fruit per plant, spreading, well-branched plants with short internodes, very pungent.

Mulato Costeño-Vendor: Seminis Vegetable Seeds. Characteristics: Open-pollinated Ancho/Mulato type, dark green to chocolate brown, wide shoulders, tapering to a point, $140 \times 76 \mathrm{~mm}$ fruit size, strong plant habit.

Nainari (PS 11406891) — Breeder and vendor: Seminis Vegetable Seeds. Parentage: F1 hybrid. Characteristics: Cayenne type; short plant; large fruit with thick walls, deep red color; early maturity; good yield. Similar: Mesilla. Adaptation: NAFTA-Northeast, main season. 2004.

Navarone-Vendor: Stokes. Characteristics: $F_{1}$ hybrid Italian ram's horn type, matures to red, extra-large, smooth, $220 \times 70 \mathrm{~mm}$ fruit size, thick flesh.

Nazas (PS 11423847) — Breeder and vendor: Seminis Vegetable Seeds. Parentage: F1 hybrid. Characteristics: Serrano type; fruit size $78 \times 20 \mathrm{~mm}$; very firm; very pungent; concentrated fruit set; fruit cylindrical with tapered tip; green to red tip; early maturity. Resistance: pepper mottle virus, potato virus y. Similar: Tuxtlas Adaptation: NAFTA-Mexico. 2004.

New Ace-Vendor: Harris Seeds. Characteristics: $F_{1}$ hybrid bell pepper, green maturing to red, early maturing, 3-4 lobed, medium thick fruit walls. Similar: Ace. 
New Orly-Vendor: Hazera Quality Seed. Characteristics: $F_{1}$ hybrid New Mexican type, green maturing to red, slender tapered fruit shape, $140 \times 30 \mathrm{~mm}$ fruit size, medium thick fruit walls, 2-lobed, pendant. Adaptation: Open field production. Resistance: Potato Virus Y, Tobacco Mosaic Virus pathotype 0.

Nimrod (HA-988) - Vendor: Hazera Quality Seed. Characteristics: $F_{1}$ hybrid bell pepper, green maturing to red, $80 \times 80 \mathrm{~mm}$ fruit size, thick fruit walls, 3-lobed, pendant. Resistance: Potato Virus Y, Tobacco Mosaic Virus pathotype 0. Adaptation: Open field and under net covering production.

Nosegay-Vendor: Seed Savers Exchange. Characteristics: Open-pollinated ornamental, $152 \mathrm{~mm}$ plant, pungent, yellow to orange to red fruit color.

NuMex Garnet-Breeder: S. Walker, M. Wall, and P.W. Bosland. Vendor: New Mexico Crop Improvement Assoc. Parentage: B-18, NMSU96C2742. Characteristics: Open-pollinated New Mexican paprika type, green maturing to red, high yielding, high ASTA color, low pungency, $118 \times 29 \mathrm{~mm}$ fruit size. Similar: NuMex Conquistador. Adaptation: Southern New Mexico production area. 2001.

NuMex Nematador-Breeder: Y. Zewdie, P.W. Bosland and S.H. Thomas. Vendor: New Mexico Crop Improvement Assoc. Parentage: Large Red Thick cayenne. Characteristics: Open-pollinated cayenne, very pungent, high yielding, $150 \times 16 \mathrm{~mm}$ fruit size, green maturing to red, plant $539 \mathrm{~mm}$ tall and $488 \mathrm{~mm}$ wide. Resistance: Southern root knot nematode race 3. Similar: Larger Red Thick. Adaptation: Southern New Mexico production area. 2001.

NuMex Suave Orange-Breeder: P.W. Bosland, E. Votava, and W. D. Adams. Vendor: New Mexico Crop Improvement Assoc. Characteristics: Open-pollinated C. chinense type, has less than 1\% the pungency of standard orange habanero cultivars, $43 \times 25 \mathrm{~mm}$ fruit size, matures from green to orange, vigorous plant habit, $838 \mathrm{~mm}$ tall and $1041 \mathrm{~mm}$ wide, with good fruit cover. Similar: Orange Habanero. Adaptation: Widely. 2001.

NuMex Suave Red-Breeder: P.W. Bosland, E. Votava, and W. D. Adams. Vendor: New Mexico Crop Improvement Assoc. Characteristics: Open-pollinated C. chinense type, has less than $1 \%$ the pungency of standard red habanero cultivars, $38 \times 31 \mathrm{~mm}$ fruit size, matures from green to red, vigorous plant habit, $889 \mathrm{~mm}$ tall and wide, with good fruit cover. Similar: Red Habanero. Adaptation: Widely. 2001.

Ohad-Vendor: Hazera Quality Seed. Characteristics: Openpollinated bell pepper, yellowish-green, $110 \times 60 \mathrm{~mm}$ fruit size, tapered shape, medium to thick fruit walls, 3-lobed, pendant. Adaptation: Open field production. Resistance: Tobacco Mosaic Virus pathotype 0 .

Ole'-Vendor: Nichols Garden. Characteristics: $F_{1}$ hybrid jalapeno, 102-mm-long fruit, pungent.

Orange Belle Hybrid II-Vendor: Burpee. Characteristics: $F_{1}$ hybrid bell pepper, 4-lobed, green maturing to orange, plants are compact and vigorous.

Orion-Vendor: Enza Zaden. Characteristics: $F_{1}$ hybrid bell pepper, green maturing to red, 90-95 $\mathrm{mm}$ fruit size, 4-lobed, thickwalled fruit, plants habit is compact, excellent leaf cover. Resistance: Bacterial leaf spot races 1, 2, 3 and 5, Tobacco Mosaic Virus. Adaptation: Open field production.

Pageant-Vendor: Roger's Brand. Characteristics: $F_{1}$ hybrid sweet banana type, large smooth fruits with good yellow color, thick fruit walls, medium tall vigorous plants. Resistance: Bacterial leaf spot races 1, 2, and 3. Adaptation: Georgia.

Palenque (SSC 4002) - Breeder: Nongwoo. Vendor: Shamrock Seed Co., Inc. Parentage: F1 hybrid. Characteristics: new serrano type pepper that is early maturing; produces a high yield of large sized fruit that is glossy, dark green that matures to red; cylindrical fruit tapers towards the blossom end; plants are medium-tall, nonpubescent; fruit setting is continuous; early maturing, concentrated set and large fruit size contribute/permit/allow high productivity/ yield. Similar: None. Resistance: None. Adaptation: All pepper production regions. 2005.

Papaloapan (PS 3545809) - Breeder and vendor: Seminis Vegetable Seeds. Parentage: F1 hybrid. Characteristics: Serrano type; fruit $8 \mathrm{~cm}$ long by $2 \mathrm{~cm}$ wide; strong plant; long shelf life; continuous fruit setting; 1300 Scoville heat units. Resistance: Potato virus Y (strain 0). Similar: Tampico Fiesta, Tuxtlas. Adaptation: NAFTA, Mexico. 2004.

Paso Real (HA-1195) — Vendor: Hazera Quality Seed. Characteristics: $F_{1}$ hybrid bell pepper, green maturing to red, $110 \times 80 \mathrm{~mm}$ fruit size, medium thick fruit walls, 3-4 lobed, pendant, plant habit medium upright. Resistance: Potato Virus Y, Tobacco Mosaic Virus pathotype 0. Adaptation: Greenhouse, plastic tunnel, and under net production.

Patriot (HMX 0640) - Breeder: Joseph Jacobs. Vendor: Harris Moran Seeds. Characteristics: $F_{1}$ hybrid bell pepper, medium green to bright red, very blocky, thick fruit walls, concentrated set, $127 \times$ $114 \mathrm{~mm}$ fruit size, 65-75 days maturity, 356-457 $\mathrm{mm}$ plant height, good foliage cover. Resistance: Bacterial leaf spot races1, 2, 3 and 5, Potato Virus Y. Adaptation: Northern and Southern U.S., especially Florida, and Mexican production areas. 2002.

Paz (HA-2001) - Breeder and vendor: Hazera Seeds. Characteristics: green to yellow blocky pepper for net and greenhouse production; fruit mostly four lobes, with thick walls, excellent firmness. Resistance: TM and OMV 2 and 3. 2002.

Pecos-Vendor: Roger's Brand. Characteristics: $F_{1}$ hybrid jalapeno, dark green maturing to red, medium pungency, easy to de-stem, tall plant with continuous set.

Peperoncino-Vendor: R.H. Shumway's. Characteristics: Open-pollinated Italian frying type, imported from Milan, high yields, thin walled, yellow-green fruits, 50-102 $\mathrm{mm}$ long, sweet, plant is $762 \mathrm{~mm}$ tall. Similar: Pepperoncini.

Perfection-Vendor: Johnny's Selected Seeds. Characteristics: $\mathrm{F}_{1}$ hybrid bell pepper, ivory white fruit ripens to lemon yellow, unlike others in this class that ripen from creamy yellow to red, sweet, 65 days to white, 85 days yellow ripe, fruit are medium to medium-large, 4-lobed, blocky, and smooth with lime-green stems, excellent fresh market type, plant habit is strong and open. Resistance: Tobacco Mosaic Virus pathotype 0 .

Perfecto-Vendor: Seminis Vegetable Seeds. Characteristics: $\mathrm{F}_{1}$ hybrid jalapeno, dark green maturing to red, $89 \times 38$ fruit size, sets well in cool weather, cylindrical fruit with a blunt end, thick walls, ideal for fresh market or processing. Resistance: Potato Virus Y.

Picante-Breeder and Vendor: Harris Moran. Characteristics: Open-pollinated jalapeno maturing from bright green to deep red, consistent shape, $25 \times 70 \mathrm{~mm}$ fruit size, upright plant habit, continuous set, and flexible branches, early maturity, withstands multiple harvests. Resistance: Tobacco Mosaic Virus.

Plato (PS 9914906) - Breeder and vendor: Seminis Vegetable Seeds. Parentage: F1 hybrid. Characteristics: green to red medium dark green bell type with large to extra large blocky, firm fruit; medium to large robust plant. Resistance: Potato virus Y, bacterial spot. Similar: Stiletto, Heritage. Adaptation: Southeast, U.S., NAFTA. 2004.

Primbo (HA-503) - Vendor: Hazera Quality Seed. Characteristics: $F_{1}$ hybrid tomato (Gambo) type, green maturing to red, $50 \times 100 \mathrm{~mm}$ fruit size, oblate, ridged fruit shape, very thick fruit walls, 4-5 lobed, pendant. Resistance: Potato Virus Y, Tobacco Mosaic Virus pathotype 0. Adaptation: Open field production.

Quadrato Asti Giallo - Vendor: Seed Savers Exchange. Characteristics: Open-pollinated Italian frying type, large, blocky, green to golden-yellow, thick crisp flesh, sweet spicy flavor.

R \& C Cayenne-Vendor: Seminis Vegetable Seeds. Characteristics: Open pollinated improved large red thick cayenne type. Similar: Large Red Thick. Adaptation: Southwestern U.S. PVP 9400086. 1994.

Rebelde (PS 11410079) — Breeder and vendor: Seminis Vegetable Seeds. Parentage: F1 hybrid. Characteristics: Ancho type; fruit size $175 \times 90 \mathrm{~mm}$; high percentage of two-locule fruit; traditional mulato dark green color turning chocolate in the ripe stage; strong plant; for fresh market and drying when red ripe color is not required. Similar: Caballero. Adaptation: NAFTA-Mexico. 2004.

Red Delicious-Vendor: Burpee Seeds. Characteristics: $F_{1}$ hybrid bell pepper, maturing green to red, when fully ripe has unique "apple" taste, delicious, fruits up to $76 \mathrm{~mm}$ across. 
Red Lion (HMX 0651) - Breeder and vendor: Harris Moran. Parentage: F1 hybrid. Characteristics: half long Lamuyo type; fruit are 3 to 4 lobed, very uniform size and shape, green to red color. Adaptation: California. 2003.

Revelation (PS 9915532) - Breeder and vendor: Seminis. Parentage: F1 hybrid. Characteristics: green to red blocky bell with large to extra large dark green, firm fruits; plant is tall with semi-open plant canopy; heavy fruit set; uniform shape. Resistance: bacterial spot, pepper mottle virus, Tobamovirus; intermediate to tobacco etch. Similar: Crusader, Wizard. Adaptation: NAFTA-Mexico. 2005.

Revolution (HMX 1660) - Breeder and vendor: Harris Moran. Parentage: F1 hybrid. Characteristics: sweet pepper; extra large blocky type; early set, cold tolerant. Resistance: BLS 1, 2, 3, 5; tolerant to CMV and Phytophthora capsici. Adaptation: U.S. 2003.

Rio De Oro (PS 11410687) — Breeder and vendor: Seminis Vegetable Seeds. Parentage: F1 hybrid. Characteristics: hot pepper; yellow to red, very large fruit, thick walls, wide shoulders, good color, 10.5 to $11.0 \mathrm{~cm}$ long; vigorous plant; good fruit set; early maturity. Similar: Sante Fe Grande, Don Nacho. Adaptation: NAFTA, Mexico. 2004.

Safi-Vendor: Technisem. Characteristics: Open-pollinated scotch bonnet type, globular wrinkled fruits, light green to bright red, 90-100 days, plant size is $300-400 \mathrm{~mm}$, very hot. Resistance: Powdery Mildew (Leveillula taurica).

Salmon-Vendor: Technisem. Characteristics: Open-pollinated Asian hot type, upright fruit cluster in concentrated fruit set (fasciculate), green maturing to a bright red, $50-80 \mathrm{~mm}$ long pointed fruit, 50-60 days for green mature fruit, very hot, plant habit is erect compact, $400 \mathrm{~mm}$ tall.

Salva Tierra (PS 11401234)—Breeder and vendor: Seminis Vegetable Seeds. Parentage: F1 hybrid. Characteristics: Pasilla type hot pepper; fruit 25 to $26 \mathrm{~cm}$ long by 3 to $4 \mathrm{~cm}$ diameter, and $64.45 \mathrm{~g}$ weight, good uniformity; strong pant; dark green fruit, turning chocolate color when ripe. Similar: Pasilla Bajio. Adaptation: NAFTA-Mexico. 2004.

Serenade-Vendor: Hazera Quality Seed. Characteristics: $F_{1}$ hybrid New Mexican type, green maturing to red, slender tapered fruit shape, $80 \times 20 \mathrm{~mm}$, thin fruit walls, 3-lobed, pendant. Resistance: Potato Virus Y, Tobacco Mosaic Virus 0. Adaptation: Open field production.

Serrano del Sol-Breeder: Seminis Seeds. Vendor: R.H. Shumway's. Characteristics: $F_{1}$ hybrid serrano type, fruit length is $102 \mathrm{~mm}$, hot, with a unique favor.

Sheepnose Pimento - Vendor: Seed Savers Exchange. Characteristics: Open pollinated tomato type, Ohio heirloom, flavorful, sweet juicy flesh, very meaty, sturdy plants.

Shemesh (HA-490) — Vendor: Hazera Quality Seed. Characteristics: $\mathrm{F}_{1}$ hybrid bell pepper, matures to gold, $80 \times 80 \mathrm{~mm}$ fruit size, medium thick fruit walls, 4-lobed, pendant, compact plant habit. Resistance: Bacterial leaf spot races 1, 2, 3, Pepper Mild Mosaic Virus, Potato Virus Y, Tobacco Mosaic Virus. Adaptation: Open field and under net production.

SM 9870 - Breeder and vendor: Samen Mauser America. Characteristics: true lamuyo pepper; very aggressive and prolific plant produces green to red fruit. Resistance: BLS race 3 and TM resistance. 1998.

Socrates (PS 304496)—Vendor: Seminis Vegetable SeedsPetoseed. Parentage: F1 hybrid. Characteristics: sweet pepper with blocky, green to red fruit; early maturity; good quality at both the green (fresh market) and red (processing) maturities; extra large size fruit with good quality; thick fruit wall with majority 3 to 4 lobed fruit; vigorous plant. Resistance: potato virus Y (strain 0), bacterial spot (race 1-3). Similar: Ironsides, Red Knight. Adaptation: Northeast U.S. 2002.

Sofia-Vendor: Stokes Seeds. Parentage: Macedonia $\times$ Bulgarian Sweet. Characteristics: F $_{1}$ hybrid Italian ram's horn type, bright red at maturity, thick flesh, deep, 2-lobed, smooth, uniform, $200 \mathrm{~mm}$ fruits.

Sparky (VTR 95)-Breeder and vendor: Orsetti Seed Co. Parentage: F1 hybrid. Characteristics: cherry bomb type; sweet but hot. Adaptation: U.S. 2000.
Staysgreen-Breeder and vendor: Stokes Seeds. Parentage: hybrid. Characteristics: F1 hybrid sweet bell pepper that stays green, $90 \times 95 \mathrm{~mm}$ sized fruit, thick flesh; matures in 75 days; medium sized "perma green" pepper has a higher sugar content than most mature red peppers; dark green fruit remains unchanged in color during the early Aug./late Sept. picking season. 1998.

Stella-Vendor: Technisem. Characteristics: $F_{1}$ hybrid Lamuyo bell pepper, dark green maturing to vivid red, $150 \times 75 \mathrm{~mm}$ fruit size, elongated, 3-4 lobed, continuous fruit set, pendant fruits, plant is $900 \mathrm{~mm}$ tall. Resistance: Tobacco Mosaic Virus.

Stiletto (RPP 8505-VP) - Vendor: Syngenta, Roger's Brand. Characteristics: $F_{1}$ hybrid bell pepper, medium dark green maturing to red, blocky to deep blocky fruits, heavy fruit set of extra large size on crown, medium tall plants with excellent plant canopy. Resistance: Bacterial leaf spot races 1,2, and 3, Tomato Spotted Wilt Virus. Adaptation: Georgia.

Striker (BS 02892230) - Breeder and vendor: Seminis Vegetable Seeds-Bruinsma. Parentage: F1 hybrid. Characteristics: yellow pepper, strong and generative, very large, blocky fruits $(88 \mathrm{~mm} \times$ $88 \mathrm{~mm}, 230 \mathrm{~g}$ ), uniform, good shelflife; must be grown in heated, high light level greenhouses (Ontario Canada, Mexico) or plastic multi-span houses with very high light levels $(>12,000$ joules per week, Mexico). Resistance: tobamovirus. Similar: Bossanova. Adaptation: NAFTA (includes Canada and Mexico. 2003.

Summer Sweet-Breeder and vendor: Twilley. Characteristics: 73 days green and 83 days red; block to deep blocky large 4- by 4-inch fruit with an extra large crown fruit set; medium to large plant size is very productive and develops smooth, high quality fruit. Resistance: tolerant to BLS races 1, 2, and 3. 1998.

Summer Sweet 209-Breeder and vendor: Abbott \& Cobb. Characteristics: consistently high yields, has strong plants with a full canopy, extra large, high quality fruit, and excellent disease tolerance. Fruits are blocky to deep blocky with thick walls and mature green in 76 days. Fruit mature red in 86 days. 2002.

Summer Sweet 290 - Vendor: Abbott \& Cobb. Characteristics: $\mathrm{F}_{1}$ hybrid bell pepper, green maturing to yellow, fruit is very large, blocky and slightly elongated, $114 \times 114 \mathrm{~mm}$ fruit size, thick walled fruit, plants are strong and has a full canopy. Resistance: Potato Virus Y, Tobacco Mosaic Virus, Stip.

Summer Sweet 830 - Vendor: Abbott \& Cobb. Characteristics: $\mathrm{F}_{1}$ hybrid bell pepper, green maturing to red, deep blocky smooth, $114 \times 102 \mathrm{~mm}$ fruit size, strong and vigorous plants. Resistance: Bacterial leaf spot race 1,2, and 3, Potato Virus Y, Tobacco Mosaic Virus. Adaptation: Early fall and spring planting in Florida.

Summer Sweet 840 - Vendor: Abbott \& Cobb. Characteristics: $\mathrm{F}_{1}$ hybrid bell pepper, green maturing to bright red, blocky, $127 \times$ $114 \mathrm{~mm}$ fruit size, strong, vigorous plants, mid- season maturity. Resistance: Bacterial leaf spot race 2, Tobacco Mosaic Virus, Potato Virus Y. Similar: Enterprise.

Summer Sweet 870 - Vendor: Abbott \& Cobb. Characteristics: $\mathrm{F}_{1}$ hybrid bell pepper, green maturing to bright red, blocky, smooth, 4-lobed, $114 \times 89 \mathrm{~mm}$ fruit size. Resistance: Bacterial leaf spot race 1, 2, and 3, Potato Virus Y, Tobacco Mosaic Virus.

Summer Sweet 880-Vendor: Abbott \& Cobb. Characteristics: $\mathrm{F}_{1}$ hybrid bell pepper, dark green maturing to bright red, large deep blocky, 4-lobed, $114 \times 102 \mathrm{~mm}$ fruit size, plants are vigorous, tall good fruit protection. Resistance: Bacterial leaf spot race 1, 2, and 3, Potato Virus Y, Tobacco Mosaic Virus. Adaptation: Wide.

Summer Sweet 890 - Vendor: Abbott \& Cobb. Characteristics: $\mathrm{F}_{1}$ hybrid bell pepper, green maturing to red, very large blocky fruit, slightly elongated, $114 \times 114 \mathrm{~mm}$ fruit size, thick walled fruit, plants are strong and has a full canopy. Resistance: Bacterial leaf spot race 1, 2, and 3, Potato Virus Y, Tobacco Mosaic Virus. Similar: King Arthur

Summer Heat 5000 (ACX P100)-Vendor: Abbott \& Cobb. Characteristics: $F_{1}$ hybrid jalapeno, dark green fruit maturing to red, $89 \times 25 \mathrm{~mm}$ fruit size, blunt, smooth cylindrical fruit, plants are very uniform upright, vigorous, providing excellent fruit cover, with continuous fruit setting ability. Resistance: Cucumber Mosaic Virus, Potato Virus Y, Tobacco Etch Virus, Tobacco Mosaic Virus. Adaptation: Most growing areas. 
Summer Heat Variety \#6000 (ACX P101)—Vendor: Abbott \& Cobb. Characteristics: $F_{1}$ hybrid jalapeno, medium green fruit maturing to red, thick walls, very cylindrical smooth fruit, $89 \times$ $25 \mathrm{~mm}$ fruit size, sturdy and full plants, excellent for processing/ dicing market.. Resistance: Cucumber Mosaic Virus, Potato Virus Y, Tobacco Etch Virus, Tobacco Mosaic Virus.

Sunny_-Vendor: Technisem. Characteristics: $F_{1}$ hybrid Asian hot type, dark green maturing to red, pendant, pointed end, 65-70 days, $130 \times 15 \mathrm{~mm}$ fruit size, upright plant habit, $1000 \mathrm{~mm}$ tall. Adaptation: Cool and dry season.

Super Flavor-Vendor: Known-You Seeds. Characteristics: $F_{1}$ hybrid, Asian hot type, $150 \times 15 \mathrm{~mm}$ fruit size, dark green maturing to bright red, prolific, smooth, good for storage and drying, vigorous plants are medium-tall, spreading.

Super Jumbo - Breeder and vendor: Liberty Seed. Characteristics: a 65 -day jalapeno; 7 inches or longer with a 1-1/4 to 1-1/2 inch diameter; almost crack free; mildly hot and smooth with no purpling. 1998.

Suryamuki Cluster-Vendor: Ecoseeds. Characteristics: Openpollinated, Asian hot type, medium-hot, small dark red fruit, borne upright on plants in clusters (fasiculate) of up to a dozen pods, very popular in India and as an ornamental.

Sweet Apple Pimiento-Vendor: Renee's Garden. Characteristics: Tomato type, shiny, many lobed fruit, emerald green maturing to deep crimson red, thick fruit walls, imported from Hungary.

Tajin (PS 11422290) - Breeder and vendor: Seminis. Parentage: F1 hybrid. Characteristics: early Jalapeno, medium plant frame with good fruit coverage, fruit are large and heavy and very uniform in shape, fruit color is medium to dark green color, thick walls, fruit shape is $90.8 \mathrm{~cm} \times 4.1 \mathrm{~cm}$, fruit set is very good and concentrated. Similar: Conchos. Adaptation: NAFTA-Mexico and Southeast U.S. 2005.

Taurus (6047A) - Vendor: Roger's Brand. Characteristics: Open-pollinated bell pepper, medium green maturing to red, 3-4 lobed, very blocky, smooth fruit, short to medium tall plants with good cover. Resistance: Tobacco Etch Virus, Tobacco Mosaic Virus. Adaptation: California, Desert Southwest. PVP 9500053. 1994.

Telestar (HA 2506) - Breeder and vendor: Hazera Seeds Inc. Characteristics: green to red, blocky bell pepper that features very smooth shoulders, large sizes, and extended setting ability. Resistance: tomato mosaic virus, potato virus Y, bacterial leaf spot races 1, 2, and 3. Adaptation: performed well in East and West coast production areas. 2005.

Telica (ACX 110) - Breeder and vendor: Abbott \& Cobb Inc. Parentage: hybrid. Characteristics: large, dark-green, bluntshaped fruit with reduced purpling and good heat; high yielding with a continuous set of attractive fruit. Resistance: bacterial leaf spot races 1,2 , and 3 , potato virus $Y$, tomato mosaic virus. 2005 .

Tennessee Cheese-Vendor: Vermont Bean and Seed Co. Characteristics: Open pollinated tomato (cheese) type pimiento, green maturing to red, $76-102 \mathrm{~mm}$ diameter fruit, strong vigorous plants.

Thai Sun-Vendor: Pepper Joe's Inc. Characteristics: Open pollinated, Asian hot type, $254 \times 305 \mathrm{~mm}$ plant size, a single plant can produce hundreds of fruits, early maturing.

Tiburon-Vendor: Sakata. Characteristics: $\mathrm{F}_{1}$ hybrid, Poblano type, very dark green maturing to red, extra large fruit, mildly pungent, mid-season maturity, large plant frame.

Time Bomb (PS 11410025) - Breeder and vendor: Seminis. Parentage: F1 hybrid. Characteristics: green to red hot cherry pepper for pickling, fruit $4 \mathrm{~cm}$ wide by $4 \mathrm{~cm}$ long, globular to pointy fruit shape, dark green turning to bright red at maturity, average fruit per plant = 38.2, 1098 Scoville heat units (fresh basis). Resistance: Tobamovirus, Pathotype Po. Similar: Grandi. Adaptation: NAFTA — Eastern United States Processors; Northwest and Southwest U.S. for home garden. 2005.

Trupti-Vendor: Ecoseeds. Characteristics: Open pollinated, Asian type, fruit is slender and long, usually curved like a fishhook, mildly hot, green turning red when ripe.
Ultra Stuff-Vendor: Stokes. Characteristics: $F_{1}$ hybrid bell pepper, light green maturing to yellow to orange to red, $150 \times 90 \mathrm{~mm}$ fruit size, slightly tapered, $2-3$ lobed, thick flesh, large vigorous plant.

Vega-Vendor: Known-You Seeds. Characteristics: $F_{1}$ hybrid, bell pepper type, $83 \times 82 \mathrm{~mm}$ fruit size, smooth, uniform fruit, plants are early, slightly dwarf with short internodes, vigorous, good wind tolerance. Resistance: Cucumber Mosaic Virus, Tobacco Mosaic Virus.

Vencedor (PS 11410055)—Breeder and vendor: Seminis Vegetable Seeds. Parentage: F1 hybrid. Characteristics: Ancho type for fresh market and drying; fruit size $16 \times 9 \mathrm{~cm}$, thick walls, medium to dark green color at fresh stage ripening into red color, two locules and wide shoulders. Similar: Caballero. Adaptation: NAFTAMexico. 2004.

Ventura (VTR 212) - Breeder and vendor: Orsetti Seed Co. Characteristics: poblano / mulato type; very good setting; mediumlong $(5 / 5 \times 3 / 5$ inch fruit; fruit are green to mulato and are generally two lobed with sunken calyx; 85-90 days to maturity. Adaptation: U.S. 2001.

Victorioso (PS 11410054) - Breeder and vendor: Seminis. Parentage: F1 hybrid. Characteristics: hybrid Ancho type for fresh market and drying; fruit size $16 \times 9 \mathrm{~cm}$; thick walls, medium to dark green color at fresh stage and ripens into red color, two locules, wide shoulders. Similar: Ancho San Martin, Tiburon. Adaptation: Mexico, Southeast and Southwest U.S. 2005.

Villano (HMX 1671) - Breeder and vendor: Harris Moran. Parentage: F1 hybrid. Characteristics: dark green, long, low anthocyanin, very pungent Jalapeno, for processing. Adaptation: U.S. 2003

Virgo - Vendor: Known-You Seeds. Characteristics: $F_{1}$ hybrid, bell pepper, green fruit, $180 \times 75 \mathrm{~mm}$ fruit size, smooth, moderately thick fruit walls, vigorous uniform plants, average plant height, wellbranched, and very prolific.

Vivaldi-Vendor: Vilmorin. Characteristics: $\mathrm{F}_{1}$ hybrid bell pepper, green maturing to red, very uniform coloration, early, $165 \times 127 \mathrm{~mm}$ fruit size, heavy, smooth, uniform, blocky, excellent first harvest, high percentage of 4-lobed, thick walls, plant is tall, medium vigor, good fruit coverage. Adaptation: Midwest and on the East Coast.

VTR 212-Breeder and vendor: Orsetti Seed. Characteristics: a medium-long pablano/mulato pepper, offers a good setting, has good wall thickness and pungency. Fruit are generally two lobed with a sunken calyx. This pepper offers relative days to maturity from transplanting of 85 to 90 days. 2002.

Whopper Improved-Vendor: Vermont Bean Seed Company. Characteristics: $F_{1}$ hybrid bell pepper, green maturing to red, $102 \times 102 \mathrm{~mm}$ fruit size, 4-lobed, thick walled fruits. Strong plant, excellent foliage protection. Resistance: Tobacco Mosaic Virus.

X3R Aristotle - Vendor: Petoseed. Characteristics: $F_{1}$ hybrid bell pepper, dark green maturing to red, 4-lobed fruit, vigorous plants. Resistance: Bacterial leaf spot races 1, 2, and 3.

X3R Ixtapa (PS 9096) - Vendor: Petoseed. Characteristics: $F_{1}$ hybrid jalapeno, matures green to red, thick-walled, tapers to point, plants are vigorous. Resistance: Bacterial leaf spot races 1, 2, and 3, Potato Virus Y, Tobacco Mosaic Virus pathotype 0.

Xena-Vendor: Sunseeds. Characteristics: $F_{1}$ hybrid jalapeno pepper, green maturing to red, smooth, mature green in 80 days, $75 \times 25 \mathrm{~mm}$ fruit size, plants are medium-large, erect, single stem with sturdy branches and good foliage canopy. Resistance: Tobacco Mosaic Virus. Similar: Jalapeno M. Adaptation: Mexico, Florida, and California.

Yellow Star-Vendor: Known-You Seeds. Characteristics: $F_{1}$ hybrid bell pepper, uniform rectangular fruit shape, brisk-green maturing to yellow, $135 \times 73 \mathrm{~mm}$ fruit size, plants are vigorous.

Yellow Monster-Vendor: Burgess Seed and Plant Co. Characteristics: Elongated bell pepper, sweet, green maturing to brilliant yellow, $178 \times 102 \mathrm{~mm}$ fruit size, plants are $686 \mathrm{~mm}$ tall.

Zarco-Vendor: Roger's Brand. Characteristics: $F_{1}$ hybrid Lamuyo bell pepper, green maturing to yellow, shiny large uniform fruit, tall vigorous plants. Resistance: Potato Virus Y, Tobacco 
Etch Virus, Tobacco Mosaic Virus, tolerance to Stip. Adaptation: California, Desert Southwest, West Mexico.

\section{PUMPKIN}

Aladdin (HMX 6689) - Breeder: Ted Superak. Vendor: Harris Moran. Parentage: F1 hybrid. Characteristics: Cucurbita pepo pumpkin; strong vine; large fruit, round to tall shape, averaging 12 inches in width and 15 inches tall; weight ranges 30 to $50 \mathrm{lb}$; large handle, firmly attached, deep orange color with moderate ribbing; thick wall. Resistance: tolerant to powdery mildew. Adaptation: U.S. 2002.

Apprentice (HMX 5682) - Breeder: Ted Superak. Vendor: Harris Moran. Parentage: F1 hybrid. Characteristics: mini pumpkin type; fruit $1 \mathrm{lb}$ or less; hard shell; round shape; high yield; unique. Adaptation: U.S. 2003.

Cannon Ball (HMX 3694) - Breeder and vendor: Harris Moran Seed Co. Characteristics: dense, 3-5 lb fruit features a vivid orange color and a large, firmly, rooted handle for a sure grip; good yield; vigorous plant. Resistance: powdery mildew tolerant. 2005.

Charisma-Breeder and vendor: Johnny's Selected Seeds. Characteristics: blocky, round medium pumpkin; fruit is slightly russeted with a deep orange color and tough green handles; weight averages 14 to $18 \mathrm{lb}$, matures late (105 days). Resistance: powdery mildew. 2005.

Cotton Candy - Breeder and vendor: Rupp Seeds, Inc. Characteristics: a true pumpkin with oval fruit; weighs 5 to $10 \mathrm{lb}$; has white rinds and white flesh that are excellent for displays or painting. 2005.

Dependable - Breeder and vendor: Abbott \& Cobb Inc. Parentage: hybrid. Characteristics: large 24-28 lb deep-round, medium-ribbed fruit; excellent dark orange color; the productive plant has a full vine. Resistance: moderate powdery mildew tolerance. 2005.

Fat Albert (MSX6099)-Breeder and vendor: Meyer Seed International. Characteristics: dark-orange, extra-large pumpkin with extra-large handle; handles are 3 inches in diameter by 10 inches long; grown on large vine; pumpkin may exceed $75 \mathrm{lb}$ under optimum conditions. 2005.

Gladiator (HMX 2689) - Breeder and vendor: Harris Moran Seed Co. Characteristics: medium-sized pumpkin; part of Warrior series; weighs $15 \mathrm{lb}$ and up; vigorous plant; good yield; excellent color; strong, large handles for easy pick-up. Resistance: powdery mildew. Adaptation: roadside markets. 2005

Gold Bullion-Breeder and vendor: Rupp Seed. Parentage: Hybrid. Characteristics: It has shown excellent performance in both Rupp and university trials, has a 100-day maturity with fruit that average $18 \mathrm{lb}$; has a dark-orange color and a strong handle. 2002

Gold Dust-Breeder and vendor: Rupp Seeds, Inc. Characteristics: darker color; better handles; 90-day semi-bush, miniature pumpkin; has out-yielded Jack-B-Quik by $20 \%$ in fruit numbers and total weight. Resistance: powdery mildew tolerance. 2005.

Gold Medal-Breeder and vendor: Rupp Seeds, Inc. Parentage: hybrid. Characteristics: top of the class in appearance for the retail marketer; 35 to $40 \mathrm{lb}$ pumpkin with a dark color and long handle; due to its early maturity ( 90 days) it will probably replace many varieties in the large-fruited class. Adaptation: can take large-fruited production much farther North. 2005.

Golden Osprey (MSX6097) - Breeder and vendor: Meyer Seed International. Characteristics: dark orange; well-ribbed, uprightround, 30-40 lb fruit; excellent handle; handles are 2 inches in diameter by 8 inches long. Resistance: moderately powdery mildew tolerant. 2005.

Hercules 3692 - Breeder and vendor: Rispens Seeds, Inc. Characteristics: beautiful, dark-orange variety; excellent yields; nice ribbing; strong handles; average weight is between 25 and 47 lb. Resistance: powdery mildew tolerance. Similar: same maturity as Aladdin. 2005.

La Estrella-Breeder and vendor: Rupp Seeds, Inc. Parentage: hybrid. Characteristics: exclusive hybrid tropical pumpkin bred for uniform size and superior flesh color; the 6-lb fruit were bred for
August and February planting in Florida and they mature in 70 days; in the Northern U.S. the growing season extends to 130 days and the fruit weigh in at 10 to $12 \mathrm{lb} .2005$.

Magician (HMX 0683) - Breeder: Ted Superak. Vendor: Harris Moran. Parentage: F1 hybrid. Characteristics: decorative pumpkin type; high yield; medium size fruit (12 to $18 \mathrm{lb}$ ); excellent orange color; round shape. Resistance: powdery mildew, ZYMV. Adaptation: U.S. 2003.

One Too Many-Breeder and vendor: Rupp Seeds, Inc. Characteristics: outstanding potential for decorative use; $15-25 \mathrm{lb}$ fruit; white with red veining; matures in 110 days on a very large vine. Resistance: good mildew tolerance plus some virus tolerance. 2005

Phat Jack-Breeder and vendor: Siegers Seed Company. Characteristics: true Jack-O-Lantern shape and color; can grow to 50-plus lb; extraordinary thick handles. 2005.

Pure Gold-Breeder and vendor: Meyer Seed International. Characteristics: dark-orange, lightly ribbed fruit; long, thick, medium dark-green handles; weighs 4 to $6 \mathrm{lb}$; excellent new pie-size pumpkin. Resistance: good disease tolerance. Adaptation: well suited for bin pack, retail sales, or school tours. 2005

Scarecrow (MSX6009) - Breeder and vendor: Meyer Seed International. Characteristics: dark-orange pumpkin; weighs $18-22 \mathrm{lb}$; round in comparison to Magic Lantern; features good ribbing and large, nearly black handles. Resistance: double powdery mildew tolerant. Adaptation: well suited for bin pack or retail sales. 2005.

Snackface (PS 9359418) - Breeder and vendor: Seminis. Parentage: F1 hybrid. Characteristics: strong semi-bush, plants that set about 6 to 8 very uniform fruits per plant; fruit are small (1-2 lb), exterior color is light orange with interior color orange; the fruits produce about $85 \mathrm{~g}$ of naked or hulless seed. Similar: Styrian Pumpkin. Adaptation: worldwide. 2005.

Super Herc (HMX 3692) - Breeder and vendor: Harris Moran Seed Co. Characteristics: large pumpkin in Warrior series; attractive 25-35 lb pumpkin; large and strong, firmly rooted handle for a good grip; shape is tall; high yield. Resistance: intermediate resistance to Powdery Mildew. Adaptation: roadside markets. 2005.

Trojan-Breeder and vendor: Seedway. Characteristics: Weighing up to $30 \mathrm{lb}$, Trojan is a deep orange pumpkin with strong large handles. Vigorous vine and high yields characterize this cultivar developed in Hershey, PA, research farm. 2002

Wyatt's Wonder (PX 159013) - Breeder and vendor: Seminis Vegetable Seeds. Parentage: inbred line. Characteristics: Halloween type giant $C$. maxima; extra large fruit with uniform size and shape, averaging 70-110 lb depending on environment and cultural practices; high round fruit shape; deep orange exterior color. Similar: Atlantic Giant. Adaptation: Northeast U.S. and home garden. PVP \#200200238. 2004.

\section{RADISH}

Discovery-Breeder and vendor: American Takii, Inc. Parentage: hybrid. Characteristics: April Cross class; slow bolting; excellent field-holding ability and uniform roots; matures in about 60 days, weighs about $800 \mathrm{~g} ; 21 / 2$ inches in diameter, roots are 15 inches long. 2005

Red Castle (HMX 4762) - Breeder and vendor: Harris Moran Seed Co. Characteristics: attractive radish produces round, uniform fruit suitable for bunching, cello, and slicing markets; exterior, bright red; interior, snow white; plant features medium erect tops; bulbs continue to size; superior yield potential; slightly earlier than Red Satin. 2005.

Red Satin (HMX 4761) - Breeder and vendor: Harris Moran Seed Co. Characteristics: attractive, general purpose radish particularly well-suited for Cello market; features vivid red exterior and a beautiful fog-white interior; holds its round shape well; highly uniform fruit; good yield; high recovery. 2005.

\section{RHUBARB}

Honeyred-Breeder and Vendor: A.J. Porter, Honeywood Nursery, Parkside, Saskatchewan, Canada. Parentage: MacDonald $\times$ Early 
Sunrise. Characteristics: stalks crisp, firm, mild; quality equal to Canada Red; same size and vigor as MacDonald; takes less sugar than most; external and internal color deeper red than MacDonald; fewer seedstalks at Parkside than any other red rhubarb tested there; susceptible to a crown rot on heavy soils. 1971.

Ruby - Breeder: Canada Dept. of Agriculture, Central Experimental Farm, Ottawa, Canada. Parentage: selected from 'Victoria'. Characteristics: stalks numerous; not as strong a grower as MacDonald, averaging $41.5 \mathrm{~cm}$ and $56 \mathrm{~g}$ in tests in New Brunswick (Agriculture Canada, Buctouche), 1982-84; Color rich ruby red, exterior redder than MacDonald and Canada Red, interior redder than MacDonald but less so than Canada Red, Sunrise and Valentine; tartness rated same as MacDonald when cooked-moderately tart, much more tart than Canada Red; color when cooked is superior to MacDonald, Canada Red, Sunrise and Valentine. Resistance: prone to numerous seed stalks and very susceptible to red leaf disease (Erwinia rhapontici). 1927.

Sunrise (Early Sunrise)—Breeder: Experimental Station, Canada Dept. Agriculture, Kentville, Nova Scotia, Canada. Parentage: Derived from 'Ruby', open-pollinated. Characteristics: Large, vigorous variety; stalks much thicker than 'Ruby'; quick to produce seedstalks; very satisfactory for forcing. Similar: to MacDonald but with much better red color. 1946.

\section{SOYBEAN}

BeSweet 2020s - Breeder and vendor: Rupp Seeds, Inc. Characteristics: new vegetable soybean; produces large beans that are sweet if picked and preserved in the proper stage; used primarily as a shelled green bean with eating quality superior to limas; higher in protein than peas or limas. 2005.

\section{SPINACH \\ Beiquan Mou \\ USDA/ARS \\ U.S. Agricultural Research Station \\ 1636 East Alisal Street \\ Salinas, CA 93905}

Admiral (SPE420) - Breeder and vendor: Sakata Seed America. Parentage: F1 hybrid. Characteristics: a fresh market and baby leaf variety, has erect, oval-shaped, medium green leaves with a slight savoy. Resistance: white rust, downy mildew races 1-2; moderate resistance to bolting. Adaptation: Texas and the East Coast of the U.S., fall and overwinter seasons.

Anna (SPF328) - Breeder and vendor: Sakata Seed America. Parentage: F1 hybrid. Characteristics: a moderately fast growing variety with an upright plant habit; medium dark green, oval leaf with a round tip; leaf becomes more round as it matures, providing a good pack for processing; smooth leaf surface with slight savoy; suitable for baby, bunch, and processing. Resistance: downy mildew races 1-10; moderate resistance to bolting.

Antelope - Breeder and vendor: Rijk Zwaan USA. Parentage: F1 hybrid. Characteristics: a semi-early cultivar, produces smooth, uniform, dark green, and upright leaves. Suitable for baby, clip, and bunch. Resistance: downy mildew races 1-12. Adaptation: U.S.

Barbados - Breeder and vendor: Seminis Vegetable Seeds. Parentage: F1 hybrid. Characteristics: a high yielding variety, produces smooth, round, dark green and pliable leaves for improved harvest quality. It is well adapted for fresh market and processing use. Resistance: downy mildew race 1-10.

Blackhawk (RS 06601122) - Breeder and vendor: Seminis Vegetable Seeds. Parentage: F1 hybrid. Characteristics: main season, summer-flowering type for sales February to May; vigorous upright plant with good heat tolerance; dark color; for processor and fresh market. Similar: Whale, Boeing. Adaptation: NAFTA. 2004.

Crescent-Breeder and vendor: Sakata Seed America. Parentage: F1 hybrid. Characteristics: medium dark green, uniform, semisavoy, oval leaf; early maturity; suitable for bunching, industry, and home garden uses. Resistance: white rust; downy mildew races $1-7,9,11$; moderate resistance to bolting. Adaptation: fall and overwinter plantings.

Cypress-Breeder and vendor: Seminis Vegetable Seeds. Characteristics: uniform dark green color, semi-savoy leaves; spring harvest; consistent performance. Resistance: downy mildew races 1-3. Adaptation: Eastern U.S.

Elfin (SPF327) - Breeder and vendor: Sakata Seed America. Parentage: F1 hybrid. Characteristics: medium green, round to oval, smooth leaf; early maturity; suitable for baby leaf. Resistance: downy mildew races 1-10, 11 (partial); moderate resistance to bolting. Adaptation: California, Arizona, and East Coast of the U.S.; year round use.

Emperor (SPF430) - Breeder and vendor: Sakata Seed America. Parentage: F1 hybrid. Characteristics: dark green, erect, round to oval, semi-savoy leaf; suitable for baby leaf. Resistance: downy mildew races 1-10; moderate resistance to bolting. Adaptation: Colorado, Texas, and the East Coast of U.S. and Canada.

Falcon (RS 1069) - Breeder and vendor: Seminis Vegetable Seeds. Parentage: F1 hybrid. Characteristics: Cool season variety, excellent vigor, high yield potential, smooth uniform leaves, even petiole length. Resistance: downy mildew race 1-7. Adaptation: U.S. fall to spring. 2001.

Imperial Green (C5-111) - Breeder and vendor: Sakata Seed America. Parentage: F1 hybrid. Characteristics: an Asian leaf type spinach used for bunching; plant habit is very erect with long stems and very dark green leaves. Resistance: downy mildew races $1-7,9$, 11; more bolt tolerant than other bunching varieties.

Mig (RS 1035) - Breeder and vendor: Seminis Vegetable Seeds. Parentage: F1 hybrid. Characteristics: smooth, glossy, dark green leaves, uniform leaf size and shape, excellent vigor for transition periods. Resistance: downy mildew race 1-7. Adaptation: U.S. 2001.

Padre (RS 06710278) - Breeder and vendor: Seminis Vegetable Seeds-Royal Sluis. Parentage: F1 hybrid. Characteristics: semi savoy leaf, very uniform, medium green color; upright and closed, well suited for fresh market; sowing dates in the Southeast are October to November; sowing dates in the Northeast are in the spring and again in September; high levels of white rust tolerance not found in any other long standing types in the market; white rust resistance and bolting tolerance make it attractive and well suited for planting east of the Mississippi River. Resistance: white rust. Similar: San Juan, Melody. Adaptation: northeast and southeast U.S. 2003.

Persius (SPC309) - Breeder and vendor: Sakata Seed America. Parentage: F1 hybrid. Characteristics: a high yielding processing type spinach; medium green, semi erect, smooth leaf with broad leaf type and good petiole length; fast bolting and early maturity. Disease resistance: white rust; downy mildew races 1, 3, 5, 8, and 9, 11 (partial). Adaptation: fall planting.

Red Kitten-Breeder and vendor: Rijk Zwaan USA. Parentage: F1 hybrid. Characteristics: has bright red stems and veins with medium green, round, and smooth leaves. Suitable for baby, clip, and bunch. Resistance: downy mildew races $1-13$. Adaptation: U.S.

Reflect (B-2759) - Breeder and vendor: Bejo Seeds. Parentage: F1 hybrid. Characteristics: semi-savoy round/oval leaves, suitable for bunch and clip, average 38 days to maturity. Resistance: downy mildew races 1-11. Adaptation: U.S. spring, summer, and fall. 2009.

Regatta (B-2758) - Breeder and vendor: Bejo Seeds. Parentage: F1 hybrid. Characteristics: round, smooth leaf, main season type suitable for bunch/baby/clip, average 41 days to maturity. Resistance: downy mildew races $1-10$. Adaptation: U.S. spring, summer, and fall. 2009.

Renegade-Breeder and vendor: Bejo Seeds. Parentage: F1 hybrid. Characteristics: dark green, smooth, round/oval leaves on tall, sweet-tasting stems, average 42 days to maturity. Resistance: downy mildew races $1-7,11$, cucumber mosaic virus. Adaptation: U.S. spring to fall. 2009.

Request (B-2757) - Breeder and vendor: Bejo Seeds. Parentage: F1 hybrid. Characteristics: round, smooth leaf, main season type suitable for bunch/baby/clip, average 41 days to maturity. Resistance: downy mildew races $1-10$. Adaptation: U.S. spring, summer, and fall. 2009. 
Revere (B-2756) - Breeder and vendor: Bejo Seeds. Parentage: F1 hybrid. Characteristics: round, smooth leaf, vigorous type suitable for bunch and clip, average 36 days to maturity. Resistance: downy mildew races 1-11. Adaptation: U.S. spring and fall. 2009.

Scarlet (SP849) — Breeder and vendor: Daenhfeldt. Parentage: hybrid. Characteristics: unique red vein; adds new dimension to baby leaf spinach marketing- color; can be used as an alternative to Swiss chard in a mixed leaf salad pack; delivers both the taste and the nutritional value spinach has to offer. Resistance: downy mildew races $1,2,3$, and 4.2005 .

SP870 - Breeder and vendor: Daenhfeldt. Parentage: hybrid. Characteristics: a full Savoy; rich dark green color; round leaf shape; fits the needs of the baby spinach grower perfectly; slow bolting, but quick to mature in warm temperatures; high quality product. Resistance: downy mildew races 1-7. 2005.

Spiros-Breeder and vendor: Bejo Seeds. Parentage: F1 hybrid. Characteristics: oval, slightly pointed leaf, dark green, very vigorous, upright, stout stems, heavy yields, average 36 days to maturity. Resistance: downy mildew races $1-5,8$. Adaptation: U.S. spring and fall.

Spitfire (RS 06602026) - Breeder and vendor: Seminis Vegetable Seeds-Royal Sluis. Parentage: F1 hybrid. Characteristics: Semi Savoy type with blistered leaves; very dark green with round leaf; nice upright plant habit with strong uniform petiole length; sow dates in North (fresh market) January-April and again August-Oct. 15; southern Europe sow dates August to mid October and January until mid February; in NAFTA DSW mid October-February and summer months elsewhere; targeted for small baby leaf market - fresh salad. Similar: Springer, Gladiator. Adaptation: NAFTA, Italy. 2003.

Unipack 131-Vendor: Seminis Vegetable Seeds. Characteristics: smooth pliable leaves, attractive color and leaf shape, uniform in shape and height. Resistance: downy mildew races 1-4, 6 (partial). Adaptation: U.S. fall to spring.

Unipack 144-Vendor: Seminis Vegetable Seeds. Characteristics: uniform smooth dark green leaves, long harvest window, upright growth facilitates mechanical harvest. Resistance: downy mildew races 1-4, 5 (partial). Adaptation: Coastal California spring to fall.

Unipack 277-Vendor: Seminis Vegetable Seeds. Characteristics: semi-savoy, dark green, glossy, attractive leaves, upright plant growth habit, uniform leaf size and height. Resistance: downy mildew races 1-4. Adaptation: U.S.

Vancouver-Vendor: Seminis Vegetable Seeds. Characteristics: large, smooth, dark green leaves, strong regrowth potential. Resistance: downy mildew races 1-3. Adaptation: Eastern U.S. fall harvest.

Whale—Breeder and vendor: Rijk Zwaan USA. Parentage: F1 hybrid. Characteristics: Features nice round, dark, uniform leaves and is suitable for baby, bunch, and cello- can be used from spring to autumn. Resistance: Downy mildew races 1-9, 11, and 12; races 10 and 13 (partial). Adaptation: U.S. 2002.

Zebu-Breeder and vendor: Rijk Zwaan USA. Parentage: F1 hybrid. Characteristics: a slow growing semi-savoy cultivar, has a very darkgreen leaf with excellent texture. Resistance: Downy mildew races $1-10$, and 12; races 11 and 13 (partial). Adaptation: U.S. summer plantings.

\section{SQUASH}

Accorny PM (HMX 9736) - Breeder: Ted Superak. Vendor: Harris Moran Seed Co. Parentage: F1 hybrid. Characteristics: winter squash type; large plant with extended setting; dark green fruit. Resistance: powdery mildew. Adaptation: U.S. 2003.

Bonbon-Breeder and vendor: Johnny's Selected Seeds. Characteristics: winter squash; 2005 All-America Selections Winner bred by Johnny's; improved taste, uniformity, and yield compared with other buttercup varieties; weight averages 4 to $5 \mathrm{lb}$ with about four fruits per plant; matures in about 95 days. 2005.

Ciclon (Ciclón, SSC 1008)_Breeder: Hollar Seeds. Vendor: Semillas Shamrock International. Parentage: F1 hybrid. Characteristics: strong plants; semi-erect with single central stem, open plant; extremely high yields; more tolerant to powdery mildew than Gray Zucchini. Similar: Gray Zucchini. Adaptation: U.S. squash production regions. 2003.

Daisey (XP 4970297) - Vendor: Seminis Vegetable SeedsAsgrow. Parentage: F1 hybrid. Characteristics: high quality, yellow straightneck type with excellent yield; excellent choice for early season planting under low virus incidence. Resistance: intermediate to powdery mildew. Similar: Enterprise. Adaptation: southeast U.S 2003.

Huasco (HMX 1718) - Breeder: Ted Superak. Vendor: Harris Moran. Parentage: F1 hybrid. Characteristics: summer squash with a tapered fruit, medium dark green color and dark green stripes. Adaptation: U.S. 2002

Judgement III (XPT 04629728) - Breeder and vendor: Seminis. Parentage: F1 hybrid. Characteristics: medium green zucchini with high productivity and a vigorous plant; fruit is glossy, speckled, cylindrical, 6 or 7 inches in length, continuous production. Resistance: Cucumber mosaic virus, Watermelon mosaic virus, Zucchini yellow mosaic virus. Similar: Tigress, Revenue. Adaptation: NAFTASoutheast United States. 2005.

Justice III (PXT 04620097) - Breeder and vendor: Seminis Vegetable Seeds. Parentage: F1 hybrid. Characteristics: medium dark green zucchini type with high yield and a vigorous bush plant; fruit at market stage are 7-8 inches long, cylindrical, smooth with waxy appearance. Resistance: Watermelon mosaic virus, Cucumber mosaic virus, Zucchini yellow mosaic virus. Similar: Dividend, Cashflow. Adaptation: NAFTA and Northeast U.S. 2004.

Leopard (HMX 2724) - Breeder and vendor: Harris Moran Seed Co. Characteristics: new, multiple virus resistant squash; easy-topick, high quality fruit from an open plant; extended harvest; reduced wind breakage. Resistance: ZYMV and PRSV. 2005.

Lynx (HMX 8714) - Breeder and vendor: Harris Moran Seed Co. Characteristics: high yield, also delivers on packout; medium to medium-dark green color. Resistance: intermediate resistance to zucchini yellow mosaic potyvirus, watermelon mosaic virus II, papaya ring spot virus. 2005.

Noche-Breeder and vendor: Syngenta Seeds, Inc./Rogers Brand. Characteristics: a new introduction for the dark green zucchini market; offers improved performance combined with disease tolerance; excellent fruit quality and good yield potential. Similar: Raven. 2005.

Obsidian-Breeder and vendor: D. Palmer Seed Co., Inc. Parentage: hybrid. Characteristics: strong qualities; open bush habit; highly productive. Resistance: extensive disease tolerance. Similar: Ambassador. 2005.

One Ball-Breeder and vendor: Hollar Seeds. Characteristics: third in series of unique squash from Hollar Seeds. Resistance: zucchini yellow mosaic potyvirus, watermelon mosaic virus. 2005.

Payroll (RSQ 0227) - Breeder and vendor: Syngenta Seeds, Inc./Rogers Brand. Characteristics: medium-green zucchini; has the potential to step forward with its virus and powdery mildew tolerance: showed high yield potential and excellent fruit quality; reduced spines. Resistance: tolerant to powdery mildew. Adaptation: wide adaptability in several Eastern growing areas. 2005.

Powergrey (HMX 8712)-Breeder: Ted Superak. Vendor: Harris Moran. Parentage: F1 hybrid. Characteristics: summer squash. Resistance: tolerance to ZYMV, WMV-2, and PRSV. Similar: Caserta. Adaptation: U.S. 2003.

QSZ 746-Breeder and vendor: Sutter Seeds LLC. Characteristics: Exhibits strong disease resistance, has an open plant with a central stalk and shows that it will yield fruit over a longer season than the competition. Resistance: PMR-1, WM2, CMV, ZYMV, and PRSV. 2002.

RB3106 - Breeder and vendor: Rupp Seeds, Inc. Characteristics: uniform fruit; new better butternut; 3-1b fruit mature in 90 days and perform well for growers needing uniformity for a boxed product; excellent interior qualities. Resistance: powdery mildew tolerance. 2005.

Royal Ace PM (HMX 9736) - Breeder: Ted Superak. Vendor: Harris Moran Seed Co. Parentage: F1 hybrid. Characteristics: winter 
squash type; large plant with extended setting; dark green fruit; formerly Accorny PM. Resistance: powdery mildew. Adaptation: U.S. 2003.

RSQ 6066-Breeder and vendor: Syngenta, Rogers Brand Vegetable Seeds. Characteristics: A virus tolerant zucchini that is very dark green in color with outstanding glossiness and fruit quality. It is an open plant that is nearly spineless for ease of picking. Resistance: Virus-tolerant. 2002.

Signature (HMX 2701) - Breeder: Clause Tezier. Vendor: Harris Moran Seed Co. Parentage: F1 hybrid. Characteristics: zucchini type summer squash with dark green fruit. Resistance: ZYMV, WMV-2, powdery mildew. Adaptation: Mexico and coastal U.S. 2003.

Sungreen (PX 4713887) - Breeder and vendor: Seminis Garden. Parentage: F1 hybrid. Characteristics: dark green zucchini with large cylindrical fruit, for fresh market, strong, single stem, open bush, compact plant. Resistance: intermediate to zucchini yellow mosaic virus and watermelon mosaic virus. Similar: Velvia. Adaptation: NAFTA. 2003.

Table Star-Breeder and vendor: Rupp Seeds, Inc. Parentage: hybrid. Characteristics: excellent yields; $50 \%$ higher sugars than competitive varieties; 2-lb, black-green acorn that matures in 70 days; fruit are marked with a white to yellow halo around the stem attachment. Resistance: powdery mildew tolerant. 2005.

Terminator (PS 04724007) - Breeder and vendor: Seminis Vegetable Seeds. Parentage: F1 hybrid. Characteristics: long, slightly lighter grey zucchini on a very vigorous plant; fruit are a medium green, speckled, medium long and slightly tapered toward the blossom end. Similar: Grey Zucchini. Adaptation: U.S. 2004.

Tlaloc (HMX 8713) - Breeder: Ted Superak. Vendor: Harris Moran. Parentage: F1 hybrid. Characteristics: Grey Zucchini type. Resistance: virus, powdery mildew. Adaptation: U.S. 2002.

Topacio (PS 13014266) - Breeder and vendor: Seminis Vegetable Seeds. Parentage: F1 hybrid. Characteristics: glossy, dark green zucchini type with good fruit length; vigorous plant; fruit length 7-8 inches. Similar: Atlantic Giant. Adaptation: NAFTA, Mexico. 2004.

Vitoria (HS 10292002)-Vendor: Seminis Vegetable SeedsHorticeres. Parentage: F1 hybrid. Characteristics: long narrow fruit with no bulb at the end; compact semi-vine plant; high yield; light greenish tan with darker green stripes; cylindrical fruit $20 \mathrm{~cm}$ long and 5-cm diameter. Similar: Menina Brasilera. Adaptation: Brazil. 2003.

Wildcat - Breeder and vendor: Harris Moran Seed Co. Parentage: F1 hybrid. Characteristics: zucchini type; medium-green; longer harvests; higher potential yield; solid disease package; mid-season; cylindrical; good green, uniform color. Resistance: intermediate resistance to zucchini yellow mosaic virus, papaya ringspot virus, powdery mildew. Adaptation: eastern U.S. 2003.

\section{SWEETCORN}

94H263 - Breeder and vendor: Seedway. Characteristics: 70-day white Se sweet corn; produces 8 -inch ears on a $51 / 2-\mathrm{ft}$, robust plant; big, vigorous plant has 24 -inch ear height, dark green husks, and ample flags; good seed vigor for early planting. 1998.

Accord-Breeder and vendor: Mesa Maize. Characteristics: a 78-day homozygous SE bicolor; widely adapted; vigorous clean plant; an excellent package, large ears with 18-inch-long 20-row count, and excellent aging quality. 2002.

Avalon-Breeder and vendor: Syngenta Seeds, Inc./Rogers Brand. Characteristics: first white in the Triple-Sweet ${ }^{\circledR}$ brand; delivers a high quality ear in about 82 days. Adaptation: suited for local and roadside markets in the Midwest and East. 2005.

Basin (XP 8492829) - Vendor: Seminis Vegetable Seeds-Asgrow Brand. Parentage: F1 hybrid. Characteristics: shrunken2 yellow processing type; full season maturity (81 days); average ear length of 9 inches $(229 \mathrm{~mm})$, with 16 to 18 rows per ear and an average diameter of 1.8 inches $(46 \mathrm{~mm})$. Resistance: common corn rust race 0 , intermediate to maize dwarf mosaic. Similar: Super Sweet Jubilee, Zenith, Challenger. Adaptation: NAFTA processing areas. 2002.

BC 0805-Breeder and vendor: Syngenta Seeds, Inc./Rogers Brand. Characteristics: first Triple Sweet ${ }^{\circledR}$ with the added benefit of Attribute ${ }^{\circledR}$ insect protection; matures in about 82 days and has well-filled ears. Resistance: resistant to some races of common rust. Adaptation: main-season plantings in the Midwest and Northeast. 2005.

Bon Appetit-Breeder and vendor: Mesa Maize. Characteristics: 70-day homozygous SE bicolor type; adapted, large plant with excellent package and blunt $73 / 4$ inch ears with 16- to 18 -row count. 2002.

Brilliance-Breeder and vendor: Harris Seeds. Characteristics: 79-day sweet corn that produces 8 - to $81 / 2$-inch ears on plants tolerant to common rust; ears have sugar-enhanced quality; easily hand harvested. 1998.

Brixmore (HMX 3825) - Breeder: Ken Christensen. Vendor: Harris Moran. Parentage: F1 hybrid. Characteristics: 85-day yellow shrunken two type, mainly for processing; ear length 9.5 inches, 2-inch diameter, with 16-18 rows. Resistance: rust, NLB, MDM and SW. Adaptation: U.S. 2003.

Brocade TSW (MXH 10502) - Breeder and vendor: Mesa Maize. Characteristics: 83-day homozygous tablesweet SE bicolor features classy $81 / 2$ inch ears with 18 rows, clean plant, easy pick. Resistance: tolerant to Stewart's wilt. 2001.

Cavalry (HMX 2374) - Breeder and vendor: Harris Moran Seed Co. Characteristics: beautiful, widely adapted bicolor Sh2 shipper; strong disease package; strong tip fill; attractive husk and flags and a tight husk cover. Resistance: intermediate resistance to Rust, Stewart's Wilt, and Common Smut; resistance to Northern Corn Leaf Blight and Maize Dwarf Mosaic. 2005.

Coho (HMX 7384) - Breeder: Ed Snyder. Vendor: Harris Moran. Parentage: F1 hybrid. Characteristics: 81 day maturity; yellow Su processing type; 7.7- to 8.0 -inch-long ear with 16-20 rows and 1.9- to 2.0-inch diameter. Resistance: Fusarium stalk rot, common smut. Adaptation: U.S. 2003.

Colonial-Breeder and vendor: Syngenta Seeds, Inc./Rogers Brand. Characteristics: mid-early bicolor; superior eating quality and flavor; good yield potential; matures in about 75 days with 16 to 18 row count. Resistance: tolerance to common rust, northern leaf blight, and Stewart's wilt. 2005.

Devotion (EX 08413133) - Breeder and vendor: Seminis. Parentage: F1 hybrid. Characteristics: high quality, shrunken 2, white type; produces 8 inch $(20 \mathrm{~cm}) \times 1.7$ inch $(4.25 \mathrm{~cm})$ ears with a nice snapped ear package and good husk cover; attractive husked ear has bright white kernels that fill 16-18 rows; matures in about 82 days; superb eating quality. Similar: Ice Queen, Summersweet $8101 \mathrm{~W}$. Adaptation: NAFTA-Northeast, Southeast and Northwest U.S. 2005.

Double Up - Breeder and vendor: Syngenta Seeds, Inc./Rogers Brand. Characteristics: bicolor supersweet; matures in 73 days; has shown consistent performance, good tip fill, larger ear size. Adaptation: Northeast, Midwest, and Southeast. 2005.

Flagship II-Breeder and vendor: Seedway. Characteristics: yellow Sh2 sweet corn that matures in 84 days; produces 7 1/2-inch ears on a $71 / 2$-ft, clean stalk; dark green husks with excellent flags. Resistance: good disease package includes added rust resistance. 1998.

Golden Blessing (XP 08590473) — Vendor: Seminis Vegetable Seeds-Seminis Garden. Parentage: F1 hybrid. Characteristics: excellent process kernel style corn with good color, early maturity, high yield in the Pacific Northwest. Resistance: intermediate to common corn rust. Similar: Rogers 1703, Sprint. Adaptation: Northwest, Midwest and Northeast U.S. 2002.

Harris (Exp 1001) - Breeder and vendor: Harris Seeds. Characteristics: homozygous SE bicolor; high eating quality in the second early time slot; refined and slightly tapered 8 -inch ears are produced in 72 days on strong clean plants; highly recommended for roadside markets that require high quality. 2002.

Harvest Gold (XP 08302418) - Breeder and vendor: Seminis. Parentage: F1 hybrid. Characteristics: SU 1 processor hybrid with refined kernel style, provides a good combination of field yield and cut kernel recovery, matures in 82 days, processed kernels are an attractive bright yellow, ears are 8.0-8.5 inches long, 2.0 inch diameter with 18-22 rows and good tip fill. Resistance: Common corn rust (Race 0); intermediate to Common corn rust (D-Virulent strain), Northern corn leaf blight and Stewart's Disease. Similar: 
Bonus, Legacy. Adaptation: NAFTA—Northeast United States main season. 2005.

HMX 8344BS - Breeder and vendor: Harris Seeds. Characteristics: similar to Candy Store but improved; 81-day supersweet bicolor has excellent eating quality, 8-inch ears, and improved disease resistance. Resistance: tolerance to common rust (RP1D), MDM, Stewart's wilt, and common smut. 2002.

Kokanee (HMX 0395) - Breeder: Ed Snyder. Vendor: Harris Moran. Parentage: F1 hybrid. Characteristics: 78 day maturity; yellow Su processing type; 8.0- to 8.5-inch-long ear with 18-20 rows and 1.9- to 2.0-inch diameter. Resistance: Fusarium stalk rot, common smut. Adaptation: U.S. 2003.

Luscious - Breeder and vendor: Johnny's Selected Seeds. Parentage: hybrid. Characteristics: organic, sweet corn; large, blocky ears; average in length from $71 / 2$ to 8 inches with 16 to 18 rows of tender, sweet kernels with good corn flavor; ears are easy to pick; widely adapted; matures in 75 days. 2005.

Max (HMX 8392S) - Breeder: Ken Christensen. Vendor: Harris Moran. Parentage: F1 hybrid. Characteristics: 85 day yellow shrunken-2 sweet corn; ear diameter is 1.8 inches, length is 7.5 inches, with 16-18 rows. Resistance: good to rust, NLB, Stewart's wilt and MDMV. Adaptation: U.S. processing as well as fresh market. 2003.

Megaton (HMX 1397) - Breeder: Ken Christensen. Vendor: Harris Moran. Parentage: F1 hybrid. Characteristics: 85-day yellow shrunken two type, mainly for processing; ear length 9.5 inches, 2 -inch diameter, with 16-18 rows. Resistance: rust, NLB, MDM and SW. Adaptation: U.S. 2003.

Millennium - Breeder and vendor: Sweet. Parentage: F1 hybrid. Characteristics: an 82-day new-generation white hybrid combining the elevated sweetness of an SH2 with the tender pericarp of an SE; 8 $1 / 2$ inch ears and outstanding eating quality. 2002.

Mirai 301BC-Breeder and vendor: Siegers Seed Company. Characteristics: bicolor sweet corn; taste, flavor, and "shipability"; tasty, loaded with sugar, and rich corn flavor; relative maturity of 76 days, $73 / 4$ inch ear; 16-row count; good tip fill. Resistance: tolerates common rust and Stewart's Wilt. 2005.

Mont Blanc (HMX 0356 WS) - Breeder: Tom Natti. Vendor: Harris Moran. Parentage: F1 hybrid. Characteristics: 79 day maturity; white Sh-2 fresh market type; ear 7.75 to 8.25 inches long with 14 to 16 kernel rows; highly resistant to most major diseases. Adaptation: U.S. 2003.

Odyssey-Breeder and vendor: Stokes Seeds. Characteristics: 80-day Sh2 bicolor; features widely adapted emergence and seed vigor; medium-sized 8-inch cylindrical ear with a tapered tip; dark green tight husks; 14 to 18 rows of well contrasted yellow and white; high sugar kernels. 1998.

Optimum - Breeder and vendor: Rispens Seeds, Inc. Characteristics: 73 day sh2 bicolor with scrumptious and tantalizing eating quality; ears are encased in a fancy package with well-filled ear and tip; very good husk cover against bird damage. 2005.

Passion+ (PS 9381169) - Breeder and vendor: Seminis Vegetable Seeds-Asgrow. Parentage: F1 hybrid. Characteristics: high quality shrunken 2 yellow type; matures in 81 days after planting; ears 8.5 inches long by 1.7 inches diameter with 18 to 20 rows; excellent package and shipping ability. Resistance: common corn rust (race 0), intermediate to northern corn leaf blight and Stewart's wilt. Similar: AC 7100. Adaptation: NAFTA-Northeast, Southeast, Northwest, Midwest U.S. 2005.

Polaris (HMX 8344BS) - Breeder and vendor: Harris Moran. Parentage: F1 hybrid. Characteristics: 81 day bicolor Sh2, for use in fresh market as well as processing; ear averages 8 inches in length and 1.8-inch diameter with a 16-18 row count; ear is slightly tapered; similar to Candy Store, but with much improved disease resistance. Similar: Candy Store. Adaptation: U.S. 2002.

Powerhouse (XP 08715864)—Breeder and vendor: Seminis Vegetable Seeds-Asgrow. Parentage: F1 hybrid. Characteristics: dark green color, strong plant with average tip fill; $21-\mathrm{cm}$ average ear length; nice cob diameter $(5.2 \mathrm{~cm}) ; 18-20$ average row count; light bright kernel color; deep kernels with excellent processed eating quality, very susceptible to Stewart's wilt. Resistance: common corn rust, maize dwarf mosaic and northern corn leaf blight. Similar: Legacy, Golden Jubilee, Cinch. Adaptation: NAFTA processor. 2003.

Prime Plus - Breeder and vendor: Syngenta Seeds, Inc./Rogers Brand. Characteristics: surpasses the competition on tip-fill; provides flavorful, cylindrical ears that look great loose or in tray packs. Resistance: common rust; tolerance to northern corn leaf blight and Stewart's wilt. 2005.

Providence (BC 4806) - Breeder and vendor: Syngenta Seeds, Inc./Rogers Brand. Characteristics: newest addition to the TripleSweet ${ }^{\circledR}$ family; a main season variety; features long, well-filled slightly tapered ears and medium-green husk; superb eating quality. Adaptation: suited for roadside and local markets. 2005.

Recovery (XP 08715864) - Breeder and vendor: Seminis Vegetable Seeds-Asgrow. Parentage: F1 hybrid. Characteristics: dark green colored strong plant with average tip fill, $21-\mathrm{cm}$ average ear length, nice cob diameter $(5.2 \mathrm{~cm}), 18-20$ average row count, light bright kernel color, deep kernels with excellent processed eating quality. Resistance: common corn rust; intermediate to maize dwarf mosaic (strain A, B) and northern corn leaf blight. Similar: Legacy, Golden Jubilee. Adaptation: NAFTA, processing. 2003.

Renaissance (HMX 0351 BES) - Breeder: Ed Snyder. Vendor: Harris Moran. Parentage: F1 hybrid. Characteristics: Sweet Generation trademark; 70 day maturity bicolor type; ear 7.5 to 8.0 inches long with 14 kernel rows, attractive dark green husk; exceptionally tender kernels with very good sweetness; must be isolated from shrunken-2 cultivars. Adaptation: U.S. 2003.

Revelation (HMX 2370) - Breeder and vendor: Harris Moran Seed Co. Characteristics: exceptional eating quality; very early, vigorous hybrid with unique tenderness and quality; good emergence in cold soils; good plant standability; attractive husk package; 66-day maturity. 2005.

Sentinel (HMX 0394S) - Breeder: Ken Christensen. Vendor: Harris Moran. Parentage: F1 hybrid. Characteristics: 83 day maturity; yellow shrunken-2 type for use in fresh market and processing; high quality; ear length 8.0 inches; 16-18 rows; strong disease package. Adaptation: U.S. 2003.

Shooting Star (HMX 8343BS) - Breeder and vendor: Harris Moran. Parentage: F1 hybrid. Characteristics: Sh2 for fresh market use, mainly as a shipper type; ear averages 7.7 inches in length and 1.8 inches in diameter with a 14-18 row count; ear is slightly tapered; good resistance to all major diseases of commercial corn; similar to Twin Star, but with much improved ear quality. Similar: Twin Star. Adaptation: U.S. 2002

Sockeye (FMX 516) - Breeder: Ed Snyder. Vendor: Harris Moran. Parentage: F1 hybrid. Characteristics: 80 day maturity; yellow Su processing type; 8-inch-long ear with 18-20 rows and 1.9- to 2.0-inch diameter. Resistance: Fusarium stalk rot. Adaptation: U.S. 2003.

Starship II-Breeder and vendor: Seedway. Characteristics: 82-day bicolor Sh2 sweet corn that produces 8-inch ears on a sturdy stalk; dark-green, tight husk bears attractive flags; high yielder. Resistance: good disease package and added rust resistance. 1998.

Summer Sweet (8101R) —Breeder and vendor: Abbott \& Cobb. Characteristics: rust-resistant, mid-season white sweetcorn; excellent emergence, vigor, and yield; medium-tall plants are tolerant to SW and northern corn leaf blight; $81 / 2$ inch ears sport bright white kernels, a row count of 16 to 18 , and excellent tip fill. 2002.

Summer Sweet 7422 — Breeder and vendor: Otis Twilley Seeds. Characteristics: shrunken bicolor sweet corn; variety matures in 75 days and produces a cylindrical ear with a 14 to 16 row count; attractive dark green husk; flag leaves wrap around an excellent kernel contrast. Resistance: SW and NCLB. 1998

Sweet Sunrise - Breeder and vendor: Rispens Seeds, Inc. Characteristics: yellow 73 day super-sweet with excellent eating quality; has a nice husk package and ear shape. 2005.

Sweet \& Sweeter (020112) — Vendor: Seminis Vegetable SeedsAsgrow Brand. Parentage: F1 hybrid. Characteristics: 82 days to maturity from planting to eating, ear length 8.0 inches; ear diameter 1.9 inches; row count is 20 to 22; color contrast (yellow/white) is 
good, very sweet. Similar: Hollywood, Madonna. Adaptation: U.S. home garden. 2002.

Sweet Talk (XP 8462518)-Breeder and vendor: Seminis. Parentage: F1 hybrid. Characteristics: shrunken 2, yellow freshmarket type; high yielding; double ear; main season (84 days to maturity); good green husk color and cover, good tip fill, ear length 7.5 inches, average row count 16-18 per ear, ear diameter 1.9 inch. Resistance: intermediate to Stewart's Disease and Northern corn leaf blight. Similar: Super Sweet Jubilee, Bandit, Summer Sweet 8100. Adaptation: NAFTA - Southeast United States and Northeast United States. 2005.

Temptation-Breeder and vendor: Seminis Vegetable Seeds. Characteristics: early bicolor with outstanding eating quality; homozygous sugar-enhanced hybrid matures in 72 days in the Northeast; has tender, very sweet kernels set in about 18 rows of 7 1/2 inch ears; excellent cold soil vigor, good tip fill and exceptional husk cover. 2002.

Vision-Breeder and vendor: Siegers Seed Company. Characteristics: 75-day yellow sweetcorn with good emergence and early vigor; ears have glossy kernels, straight rows, and excellent tip fill, best part is its eating quality; juicy kernels. 2005 .

Whiteout TSW (MXH 11181W) - Breeder and vendor: Mesa Maize. Characteristics: 73-day homozygous tablesweet SE white with 8-inch ears, 16 rows of bright white kernels; sturdy, clean, vigorous, featuring a classy package and ear conformation. 2002.

Wilda's Pride - Breeder and vendor: Harris Seeds. Characteristics: ornamental corn; one of the most unique ornamentals in today's market; large ears with a wide diversity of colors measure 8 to 11 inches and are produced on tall, sturdy plants. 1998.

Winstar-Breeder and vendor: Syngenta Seeds, Inc./Rogers Brand. Characteristics: full-season shipper, exceptionally clean plant; has a short shank that pulls easy and attractive dark-green ears. Resistance: strong disease package including resistance to common rust and tolerance to northern leaf blight and Stewart's wilt. 2005.

\section{SWISS CHARD}

Bright Lights-Breeder and vendor: Johnny's Selected Seeds. Characteristics: AAS winner; features multi-colored stems, and lightly savoyed green and bronze leaves; taste is milder than ordinary chard; colorful bedding/ornamental plant is suitable for year-round production-28 days baby, 55 days bunching. 2001.

\section{TOMATO}

John W. Scott
Gulf Coast REC
University of Florida
14625 CR 672, Wimauma, FL 34203

Amai (STM7704) - Breeder and vendor: Sakata Seed America, Inc. Characteristics: Indeterminate grape. vigorous plant with high productivity; good flavor with good fruit size and shape; uniformity throughout the plant. Resistances: Fusarium wilt race 1, tomato Mosaic Virus races 0, 2 gray leaf spot, nematodes, leaf mold races A-E. Adaptation: indoor and outdoor production. 2011.

Amelia VR (HMX 0800)—Breeder: North Carolina State University Vendor: Harris Moran. Characteristics: Determinate vine, for fresh market tomato growers in Fusarium 3 and Tomato Spotted Wilt Virus-plagued areas; High fruit quality and high yields. Resistance: Verticillium wilt race 1, Fusarium wilt races 1, 2, and 3, tomato spotted wilt virus, nematodes. 2005.

B-52 (PS 151052) - Breeder and vendor: Seminis. Parentage: F1 hybrid. Characteristics: fresh market type, very strong indeterminate plant, medium-large fruit, oblate, very firm fruit with good color at maturity; fruit size $200 \mathrm{~g}$. Resistance: Alternaria stem canker, tomato mosaic virus (strain $0-2$ ), Verticillium wilt Race 1, tomato yellow leaf curl virus, Fusarium wilt races 1 and 2. Similar: Charleston. Adaptation: Southeast and Mexico. 2005.
B807-Breeder and vendor: Meyer Seed International. Characteristics: extra-large; long shelf-life; smooth, round, uniform, and firm; fruit weight averaged $15.7 \mathrm{oz}$ with some fruit weighing $27 \mathrm{oz}$. Adaptation: well suited for local fresh market or long-distance shipping. 2005.

Bella Rosa-Breeder: Sakata Seed America and the University of Florida. Vendor: Sakata Seed America, Inc. Characteristics: Determinate round, compact plant with large, high quality globe shaped fruit, good hot and vine ripe use. Resistance: Verticillium wilt race 1, Fusarium wilt races 1 and 2, alternaria stem canker, gray leaf spot, tomato spotted wilt virus. Adaptation: Southeastern US. 2005.

BHN 268-Breeder and vendor: BHN Seed. Parentage: Hybrid. Characteristics: Firm cherry tomato that features outstanding yields of uniform, medium size. Excellent shelf life and taste make this an ideal cherry for shipping, local-market growers or home gardeners. Resistance: Verticillium race 1, Fusarium wilt race 1.2002.

BHN 589-Breeder and vendor: BHN Seed. Parentage: F1 hybrid. Characteristics: Determinate fresh market round type with very good flavor. Resistance: Verticillium wilt race 1, Fusarium wilt races 1 and 2, tomato mosaic virus. Adaptability: for vine ripe or roadside stand production in open fields or high tunnels. 2003

BHN 602-Breeder and vendor: BHN Seed. Parentage: F1 hybrid. Characteristics: Determinate fresh market round type with tomato spotted wilt virus resistance. Resistance: Verticillium wilt race 1 , Fusarium wilt races 1,2 , and 3, tomato spotted wilt virus. Adaptability: for eastern U.S. vine ripe or gas green production. 2004

BHN 685-Breeder and vendor: BHN Seed. Parentage: F1 hybrid. Characteristics: Determinate fresh market roma type with tomato spotted wilt virus resistance. Resistance: Verticillium wilt race 1 , Fusarium wilt races 1,2 , and 3 , tomato spotted wilt virus. 2003

BHN 730-Breeder and vendor: BHN Seed. Parentage: F1 hybrid. Characteristics: Determinate fresh market round type with resistance to Fusarium crown rot. Resistance: Verticillium wilt race 1, Fusarium wilt races 1 and 2, Fusarium crown and root rot, bacterial speck. Adaptability: for gas green production in the southeast U.S. 2010

BHN 785-Breeder and vendor: BHN Seed. Parentage: F1 hybrid. Characteristics: Determinate fresh market grape type with high yields of uniform grape shaped fruit. Resistance: Fusarium wilt race 1.2005

BHN 876-Breeder and vendor: BHN Seed. Parentage: F1 hybrid. Characteristics: Determinate fresh market high beta round type with beautiful orange/gold color and great taste and texture. Resistance: Verticillium wilt race 1, Fusarium wilt races 1 and 2, tomato mosaic virus. 2007

BHN 1064-Breeder and vendor: BHN Seed. Parentage: F1 hybrid. Characteristics: Determinate fresh market round type with resistance to tomato spotted wilt virus. Resistance: Verticillium wilt race 1, Fusarium wilt races 1,2 , and 3 , tomato spotted wilt virus. Adaptability: for gas green and vine ripe production throughout the eastern U.S. 2011

Biltmore (XP 1417977) — Breeder and vendor: Seminis Vegetable Seeds-Asgrow. Parentage: F1 hybrid. Characteristics: fresh market type; tall jointed determinate plant with large, smooth, heavy fruit that is uniform; no green shoulders; not as early as Mountain Spring, but stronger plant better quality fruit that are larger size at top of plant; maturity earlier than Florida 47 and 91. Resistance: alternaria stem canker, Verticillium wilt race 1, Fusarium wilt races 1 and 2, gray leaf spot. Similar: Sunpride, Sunbeam. Adaptation: eastern U.S. 2003.

Camel (HMX 4793) - Breeder and vendor: Harris Moran Seed Co. Parentage: F1 hybrid. Characteristics: determinate fresh market type; fruit are extra large, round, very firm. Resistance: Fusarium wilt races 1 and 2, Verticillium wilt race 1, nematodes gray leaf spot, tomato spotted wilt virus. Similar: Saladette, Roma. Adaptation: California, Mexico. 2003. 
Capaya (PS 151476) - Vendor: Seminis Vegetable Seeds-Petoseed. Parentage: F1 hybrid. Characteristics: vigorous, determinate, long shelf-life, saladette type; large plant; may work on ground or staked; fruit are semi-elongated, very smooth with good girth; very firm fruit with good color. Resistance: alternaria stem canker, nematodes, Fusarium wilt race 1, gray leaf spot, Verticillium wilt, tomato spotted wilt virus. Similar: Toro, Conquistador. Adaptation: NAFTAMexico. 2004.

Cardinal-Breeder and vendor: D. Palmer Seed, Co., Inc. Parentage: hybrid. Characteristics: indeterminate cherry tomato produced on alternating stems; outstanding bright red color and old-fashioned tomato taste; oval shaped hybrid weighs between 12 and 18 g. 2002.

Celebrity-Breeder and vendor: Seminis. Characteristics: Productive plants yield high quality, large, smooth fruit with outstanding flavor; deep oblate fruit shape; fruit size $8 \mathrm{oz}(227 \mathrm{~g})$; large determinate plant type; relative maturity 72 days. Resistance: Alternaria stem canker, Fusarium wilt Race 1 and 2, Gray leaf spot, Southern rootknot nematode, Tomato mosaic virus, Verticillium wilt Race 1. Adaptation: Widely adapted fresh market and home garden variety; thrives in many climates. 1975.

Charger-Breeder and vendor: Sakata Seed America, Inc. Characteristics: Determinate round, medium large plant with large and extra-large, firm fruit. Resistance: Verticillium wilt race 1, Fusarium wilt races 1, 2, and 3, alternaria stem canker, gray leaf spot, tomato yellow leaf curl virus. Adaptation: Eastern US, Central America. 2009.

Charleston (GC 18041)-Breeder and vendor: Syngenta, Rogers Brand Vegetable Seeds. Characteristics: An indeterminate beef tomato with a long shelf life and high yields. It has globe-shaped fruit, weighs 210 to $220 \mathrm{~g}$, and features smooth uniform shoulders and a small blossom scar. 2002.

Crista-Breeder: North Carolina State University. Vendor: HMClause. Parentage: F1 hybrid of NC 84173PVP $\times$ NC 123 S. Characteristics: Fresh market type for vine ripe/ mature green harvest production, medium tall determinate plant with dark green slightly open foliage cover, early mid season maturity, extra large, firm, crack resistant, smooth fruit with good flavor, tendency for soft fruit under high temperature conditions. Resistance: Fusarium wilt races 1, 2, and 3 , Verticillium wilt race 1, root knot nematodes, tomato spotted wilt virus. 2005.

Crown Jewel-Breeder: Seminis and University of Florida. Vendor: Seminis. Characteristics: $\mathrm{F}_{1}$ hybrid, fresh market, determinate, medium tall plants, main season, deep oblate to globe fruit, uniformly-colored shoulders, jointed pedicels. Resistance: Verticillium wilt race 1, Fusarium wilt races 1 and 2, gray leaf spot, alternaria stem canker, Fusarium root and crown rot. Adaptation: South Florida. 2005.

Cupid (PS 01502036) - Breeder and vendor: Seminis Vegetable Seeds-Petoseed. Parentage: F1 hybrid. Characteristics: fresh market type; vigorous indeterminate vine; big cherry with Saladette shape; small oval fruit size of grape type; cluster sets; high sugar content (8.2 brix). Resistance: Fusarium wilt races 1 and 2; alternaria stem canker; bacterial speck race 0; gray leafspot. Similar: Santa. Adaptation: NAFTA. 2003.

Defiant PhR - Breeder and vendor: Johnny's Selected Seeds. F1 hybrid. Characteristics: Midseason, local and regional fresh market. Fruit globe, red, medium-firm, green shoulder, avg. 175 g. Determinate. Resistance: Verticillium wilt race 1, Fusarium wilt races 1 and 2, early blight (stems), late blight ( $\mathrm{Ph} 2$ and $\mathrm{Ph} 3$ heterozygous.) Adaptation: temperate. 2011.

Five Star Grape-Breeder and vendor: Johnny's Selected Seeds. F1 hybrid. Characteristics: early, fresh market. Fruit oblong cherry ("grape"), red, thin skin, green shoulder, flavorful, good shelf life, avg. 15-20 g. Indeterminate. Resistance: Verticillium wilt race 1, Fusarium wilt races 1 and 2, early blight (horizontal.) Similar: Santa. Adaptation: wide. 2011.

Fletcher-Breeder: North Carolina State University. Vendor: Bejo Seeds (Seedway). Parentage: NC 84173PVP $\times$ NC 132S. Characteristics: Fresh market type for vine ripe production, similar to Mountain Spring but with TSWV and root knot nematode resistances, medium tall determinate plant with slight foliage curl, concentrated set of extra large, very firm, highly crack resistant fruit with pinpoint blossom end scars. Resistance: Fusarium wilt races 1 and 2, Verticillium wilt race 1, root knot nematodes, tomato spotted wilt virus. 2007.

Glory (025239) - Breeder and vendor: Seminis Vegetable Seeds-Seminis Garden. Parentage: F1 hybrid. Characteristics: fresh market tomato, large, indeterminate plant. Resistance: alternaria stem canker; Fusarium wilt races 1 and 2; Verticillium wilt race 1; gray leafspot. Similar: none. Adaptation: NAFTA. 2003.

Golden Sweet Grape - Breeder and vendor: Johnny's Selected Seeds. Characteristics: yellow grape tomato; firm; bite-size; grow in long clusters on tall plants; indeterminate; mild, sweet flavor; resists cracking and matures in 60 days. 2005.

H2005 - Breeder and vendor: H.J. Heinz. Characteristics: Hybrid peel/dice tomato with medium viscosity, full season, large prostrate vine, elongated-square fruit, very high ${ }^{\circ}$ Brix. Resistances: Verticillium wilt race 1, Fusarium wilt race 1 and 2, nematodes, bacterial speck. Adaptability: California, Latin America. 2007

H2206 - Breeder and vendor: H.J. Heinz. Characteristics: Hybrid paste tomato, ultra-early maturity ( 99 days), small/compact prostrate vine, sets well in heat, uniform round jointless fruit $(60 \mathrm{~g})$ susceptible to bursting. Resistances: Verticillium wilt race 1, Fusarium wilt race 1, rot resistant. Adaptability: broad adaption. 2008

H2401-Breeder and vendor: H.J. Heinz. Characteristics: Hybrid paste tomato, full season, large semi-prostrate vine, 70-g blocky-oval fruit with very high juice viscosity. Resistances: Verticillium wilt race 1, Fusarium wilt race 1 and 2, nematodes, bacterial speck, rot resistant (extended field storage). Adaptability: humid and arid regions. 2003

H3402 - Breeder and vendor: H.J. Heinz. Characteristics: Hybrid peel/dice tomato with medium viscosity, mid-full season, large semiprostrate vine, and $65 \mathrm{~g}$ blocky-oval fruit with excellent field rot resistance. Resistances: Verticillium wilt race 1, Fusarium wilt race 1 and 2, nematodes, bacterial speck. Adaptability: Broadly adapted. 2004

H4007-Breeder and vendor: H.J. Heinz. Characteristics: Hybrid peel/dice tomato with medium juice viscosity, second-early maturity, medium/large semi-prostrate vine, jointless blocky fruit $(75 \mathrm{~g})$ with very good color. Resistances: Verticillium wilt race 1, Fusarium wilt race 1 and 2, nematodes, bacterial speck, rot resistant. Adaptability: Humid and arid regions. 2009

H4107-Breeder and vendor: H.J. Heinz. Characteristics: Hybrid peel/dice tomato with low viscosity, mid season, medium vine with excellent cover, smooth oval fruit. Resistances: Verticillium wilt race 1, Fusarium wilt race 1 and 2, rot resistant. Adaptability: Humid regions. 2009

H5003 - Breeder and vendor: H.J. Heinz. Characteristics: Hybrid peel/dice tomato with medium viscosity, second early maturity, medium/large semi-prostrate vine with adequate fruit cover, excellent field yield, $70 \mathrm{~g}$ blocky fruit. Resistances: Verticillium wilt race 1, Fusarium wilt race 1 and 2, nematodes, bacterial speck. Adaptability: Arid regions. 2005

H5108 - Breeder and vendor: H.J. Heinz. Characteristics: Hybrid peel/dice tomato with medium viscosity, early maturity, compact vine with excellent fruit cover, $70 \mathrm{~g}$, jointless fruit is blocky, smooth and firm. Resistances: Verticillium wilt race 1, Fusarium wilt race 1, rot resistant. Adaptation: Humid regions. 2010

H5508 - Breeder and vendor: H.J. Heinz. Characteristics: Hybrid paste tomato, full season, very large semi-prostrate vine with good foliar cover, jointless $85 \mathrm{~g}$ blocky fruit. Resistances: Verticillium wilt race 1 , Fusarium wilt race 1 and 2 , nematodes, tomato spotted wilt virus, rot resistant (extended field storage). Adaptability: Arid regions. 2010

H5608 - Breeder and vendor: H.J. Heinz. Characteristics: Hybrid paste tomato, full season, large prostrate vine with good foliar cover, jointless blocky-oval fruit ( $80 \mathrm{~g}$ ). Resistances: Verticillium wilt race 1, Fusarium wilt race 1 and 2, nematodes, tomato spotted wilt virus. Adaptability: Arid regions. 2010

H7709-Breeder and vendor: H.J. Heinz. Characteristics: Hybrid peel/dice tomato with medium juice viscosity, full season, large semi-prostrate vine, jointless, $95 \mathrm{~g}$ blocky-oval shaped fruit. 
Resistances: Verticillium wilt race 1, Fusarium wilt race 1 and 2, nematodes, bacterial speck. Adaptability: Arid regions. 2011

H8004-Breeder and vendor: H.J. Heinz. Characteristics: Hybrid peel/dice tomato with medium viscosity, full season, medium/large prostrate vine with dense cover, elongated oval fruit. Resistances: Verticillium wilt race 1, Fusarium wilt race 1 and 2, nematodes, bacterial speck, rot resistant. Adaptability: Arid regions. 2006

H8504-Breeder and vendor: H.J. Heinz. Characteristics: Hybrid paste tomato, full season, medium/large prostrate vine with excellent dense cover, blocky-oval shaped fruit. Resistances: Verticillium wilt race 1, Fusarium wilt race 1 and 2, nematodes, bacterial speck, and very rot resistant (extended field storage). Adaptability: Arid regions. 2006

H9553 - Breeder and vendor: H.J. Heinz. Characteristics: Hybrid paste tomato, late season, large prostrate vine, jointless, $65 \mathrm{~g}$, oval fruit. Resistances: Verticillium wilt race 1, Fusarium wilt race 1 and 2, nematodes, bacterial canker, bacterial spot, rot resistant. Adaptability: Humid and arid climates. 1997

H9661 - Breeder and vendor: H.J. Heinz. Characteristics: Hybrid peel/dice tomato with medium viscosity, second early maturity, medium semi-prostrate vine, jointless, $80 \mathrm{~g}$ blocky fruit high ${ }^{\circ}$ Brix. Resistances: Verticillium wilt race 1, Fusarium wilt race 1 and 2 , nematodes, bacterial speck. Adaptability: Humid and arid climates. 1998

H9780 — Breeder and vendor: H.J. Heinz. Characteristics: Hybrid paste tomato suitable for peel/dice applications, full season, large, semi-prostrate vine with adequate fruit cover, blocky-shaped jointless 90-g fruit with high ${ }^{\circ}$ Brix and good color. Resistances: Verticillium wilt race 1, Fusarium wilt race 1 and 2, nematodes, bacterial speck, rot resistant. Adaptability: arid climates. 2001

H9881 - Breeder and vendor: H.J. Heinz. Characteristics: Hybrid peel/dice tomato with medium viscosity, early maturity (112 days), medium semi-prostrate vine with excellent setting, jointless $65 \mathrm{~g}$ round fruit. Resistances: Verticillium wilt race 1, Fusarium wilt race 1 and 2, nematodes, bacterial speck, rot resistant. 2000

H9997-Breeder and vendor: H.J. Heinz. Characteristics: Hybrid paste tomato, midseason, medium-small prostrate vine, 80 -g blockyshaped fruit with high lycopene. Resistances: Verticillium wilt race 1, Fusarium wilt race 1 and 2, nematodes, bacterial speck. Adaptability: humid and arid regions. 2001

Indy-Breeder and vendor: Syngenta Seeds, Inc./Rogers Brand. Characteristics: high-quality fruit are extra-large and large beef-type that have shown good flavor and color; Resistance: Fusarium wilt race 1 and 2, Verticillium wilt race 1, gray leaf spot. Adaptation: Mid-Atlantic and Northeast regions. 2005.

IRT-04-119 - Breeder and vendor: D. Palmer Seed Co., Inc. Parentage: hybrid. Characteristics: indeterminate roma/saladette; excellent disease tolerance; dense, thick flesh; uniform ripening with great firmness and excellent brix; produces large fruit weighing up to 4.5 ounces. 2005.

Jolly Elf-Breeder and vendor: Siegers Seed Company. Parentage: hybrid. Characteristics: grape tomato; grows on a 5 -ft determinate plant; has extended market life on the plant and on the shelf; fruit have glossy red color; weighs between 8 and $15 \mathrm{~g}$; have an average of $10 \%$ brix. 2005.

Loreto (PS 1830837) - Breeder and vendor: Seminis Vegetable Seeds-Petoseed. Parentage: F1 hybrid. Characteristics: indeterminate, fresh market saladette, vigorous plant, good set jointed pedicel, uniform green, very tall plants with excellent fruit coverage, constant set, fruits are uniform in shape, extra large size. Resistance: nematodes, Fusarium wilt race 1, alternaria stem canker, tomato mosaic virus, Verticillium wilt race 1. Similar: Tequila; Romana; Xena; Silvestre. Adaptation: Mexico, South America. 2002.

Majestad (SSC 1020) - Breeder and vendor: Shamrock Seed Co. Parentage: F1 hybrid. Characteristics: strong, determinate plant with good cover; firm and good sized fruit (110 to $120 \mathrm{~g}$ ); bright red at maturity. Resistance: Verticillium wilt race 1, Fusarium wilt race 1 and 2, nematodes, bacterial speck. Similar: Rio Grande. Adaptation: all tomato growing regions. 2003.

Mariaitalia (159278) - Breeder and vendor: Seminis Vegetable Seeds-Petoseed. Parentage: F1 hybrid. Characteristics: Fresh market indeterminate tomato with large fruit size (180-250 g), uniform color for greenhouse crops, very early maturity, short internodes, firm fruit. Resistance: Fusarium wilt races 1, 2, and 3, nematodes, tomato mosaic virus, Verticillium wilt race 1. Similar: Noa. Adaptation: South America. 2003.

Mariana-Breeder and vendor: Sakata Seed America, Inc. Characteristics: Determinate saladette, compact plant with large to extra-large, high quality fruit, high yield potential. Resistance: Verticillium wilt race 1, Fusarium wilt races 1 and 2, alternaria stem canker, gray leaf spot, nematodes. Adaptation: wide, staked and ground culture. 2002.

Martha Washington-Breeder and vendor: Johnny's Selected Seeds. F1 hybrid. Characteristics: Midseason, local fresh market. Fruit oblate, pink, soft, multilocular, green shoulder, flavorful, avg. 227-340 g. Indeterminate. Adaptation: temperate. 2012.

Matt's Wild Cherry - Origin: Mexico, land race, S. lycopersicum cerasiforme. Vendor: Johnny's Selected Seeds. Characteristics: early, local fresh market. Fruit round, red, soft, green shoulder, highly flavorful, avg. 10 g. Vigorous indeterminate. Resistance: early blight (horizontal), late blight (horizontal.) Adaptation: wide. 1986.

Mini Charm-Breeder and vendor: D. Palmer Seed Co., Inc. Parentage: hybrid. Characteristics: indeterminate cherry/cocktail tomato; can be grown as an open field or greenhouse variety; may bear 20 to 60 fruit per cluster; bright red; good shelf-life; high sugar content and special flavor. 2005.

Miroma (RFT 0992) - Breeder and vendor: Syngenta Seeds, Inc./Rogers Brand. Characteristics: raises the bar for determinate saladette tomatoes in California's San Joaquin Valley; in trials, this large, blocky, deep-red saladette produced high yields of smooth, firm, principally extra-large and large fruit approximately 5 days earlier than Monica. 2005.

Monica-Breeder and vendor: Sakata Seed America, Inc. Characteristics: Determinate saladette, large, vigorous plant with large to extra large fruit, tapered, variable shape, deep red color. Resistance: Verticillium wilt race 1, Fusarium wilt races 1 and 2, alternaria stem canker, gray leaf spot, bacterial speck. Adaptation: wide, ground culture in California. 2000.

Monarca (SSC 1454) — Vendor: Shamrock Seed Co. Parentage: F1 hybrid. Characteristics: high yielding and widely adapted Saladette type; indeterminate plant with vigorous growth and thick, sturdy branches able to withstand pruning to one or two stems; uniform crop of large fruit weighing 3.5-4.5 ounces; oblong shaped fruit with uniform, red coloring; excellent shipping quality and a relatively long shelf life; 80-90 days relative maturity. Resistance: Verticillium wilt race 1, Fusarium wilt races 1 and 2, bacterial speck. Adaptation: tomato growing regions of Mexico. 2004.

Mountain Crest (NC 98100) - Breeder: North Carolina State University. Vendor: Nunhems. Parentage: F1 hybrid of NC $84173 \mathrm{PVP} \times \mathrm{NC} 1$ rinEC. Characteristics: Long shelf life rin hybrid for vine ripe production, large to extra large, smooth, firm, highly crack resistant fruit with good external and interior color and flavor, tall determinate plant with good foliage cover, moderate heat set ability. Resistance: Fusarium wilt races 1 and 2, Verticillium wilt race 1. HortScience 41:261-262. 2002.

Mountain Fresh Plus (HMX 2807)—Breeder: North Carolina State University Vendor: Harris Moran Seed Co. Parentage: F1 hybrid. Characteristics: determinate type; vigorous plant; extra large round fruit. Resistance: Fusarium wilt races 1 and 2, Verticillium wilt race 1, Adaptation: California, eastern U.S. 2003.

Mountain Glory-Breeder: North Carolina State University. Vendor: Rogers division of Syngenta. Parentage: F1 hybrid of NC 84173PVP $\times$ NC 58S. Characteristics: Fresh market type for vine ripe production, similar to Mountain Spring but TSWV resistant, medium tall determinate plant with slight foliage curl, concentrated set of extra large, very firm, highly crack resistant fruit with pinpoint blossom end scars. Resistance. Fusarium wilt races 1 and 2, Verticillium wilt race 1, tomato spotted wilt virus. 2007.

Mountain Magic (NC 0650)-Breeder: North Carolina State University. Vendor: Bejo Seeds. Parentage: F1 hybrid of NC 2CELBR 
$\times$ NC 2grape. Characteristics: Compact indeterminate cocktail type, similar to Campari but adapted to field production for vine ripe production; firm, crack resistant, high sugar, good flavor, extended shelf life rin hybrid. Resistance: Fusarium wilt races 1 and 2, Verticillium wilt race 1, early blight, late blight (heterozygous $\mathrm{Ph}-2$ and $\mathrm{Ph}-3$ genes). HortScience 46:1321-1323. 2008.

Mountain Majesty (NC 0848) - Breeder: North Carolina State University. Vendor: HMClause. Parentage: F1 hybrid of NC $714 \times$ NC 1CS. Characteristics: Fresh market type for vine ripe/ mature green harvest, tall determinate, mid season, extra large, smooth, firm, crack resistant fruit, excellent interior color (homozygous crimson). Resistance: Fusarium wilt races 1 and 2, Verticillium wilt race 1, tomato spotted wilt virus. HortScience 46:1321-1323. 2011.

Mountain Merit (NC 0694)-Breeder: North Carolina State University. Vendor: Bejo Seeds. Parentage: F1 hybrid of NC $123 \mathrm{~S} \times$ NC 1CELBR. Characteristics: Fresh market type for vine ripe/ mature green harvest, tall determinate, mid season, extra large, smooth, firm, crack resistant fruit. Resistance: Fusarium wilt races 1, 2, and 3, Verticillium wilt race 1, root knot nematodes, tomato spotted wilt virus, late blight (heterozygous $\mathrm{Ph}-2$ and $\mathrm{Ph}-3$ genes). HortScience 45:1547-1548. 2010.

Muriel-Breeder and vendor: Sakata Seed America, Inc. Characteristics: Saladette type with comparable shape, yield, and size to Monica; jointed and has a uniform shoulder. Similar: Monica. Resistance: nematodes, tomato spotted wilt virus. Adaptation: performs well in the Southeast. 2005.

Mykonos (PS 151123) - Breeder and vendor: Seminis Vegetable Seeds-Petoseed. Parentage: F1 hybrid. Characteristics: fresh market type; medium-large determinate plant; large deep oblate fruit; uniform green, very firm; good mature color; ripens well with ethylene. Resistance: gray leafspot, Fusarium wilt races 1 and 2, tomato mosaic virus, tomato yellow leaf curl virus Verticillium wilt race 1, alternaria stem canker. Similar: Acclaim, Shady Lady. Adaptation: California. 2003.

Navidad-Breeder and vendor: Syngenta Seeds, Inc., Rogers Brand Vegetable Seeds. Characteristics: Navidad has shown to remain firm throughout the distribution chain and has the ability to maintain its shape during environmental stress. 2002.

Pampero (PS 150351) - Breeder and vendor: Seminis Vegetable Seeds-Petoseed. Parentage: F1 hybrid. Characteristics: very strong, widely adaptable plants; good fruit set; smooth, jointless, uniform green. Resistance: Gray leaf spot, nematode, alternaria stem canker, Fusarium wilt races 1 and 2, Verticillium wilt race 1, intermediate to bacterial speck. Similar: Yaqui. Adaptation: South America, Mexico. 2003.

Paradise (199296) - Breeder and vendor: Seminis Vegetable Seeds-Asgrow. Parentage: F1 hybrid. Characteristics: uniform green, deep oblate to round fresh market type; fruit sets well under hot temperatures; fruit size is large to extra large with uniform color; plant is vigorous. Resistance: gray leaf spot, alternaria stem canker, tomato spotted wilt virus, Verticillium wilt, Fusarium wilt races 1 and 2. Similar: BHN 444. Adaptation: Argentina. 2003.

Paragon-Breeder and vendor: Johnny's Selected Seeds. Parentage: Hybrid. Characteristics: Paragon is the first organically grown hybrid tomato. This heavy-hitting, main crop shipper is popular with growers in the East and Midwest. It is a vigorous, 78-day determinate with a vine that produces a heavy set of large smooth firm, good tasting globes. 2002.

Phoenix-Breeder and vendor: Seminis. Characteristics: $F_{1}$ hybrid, fresh market, main season, hot-set, vigorous plant, good leaf cover, high fruit quality, firm, globe-shaped fruit, uniformlycolored, jointed pedicles, large to extra-large. Resistance: Verticillium wilt race 1 , Fusarium wilt races 1 and 2 , gray leaf spot, alternaria stem canker. Adaptation: Southeast US

Picus-Breeder and vendor: Seminis. Characteristics: $F_{1}$ hybrid, main season, determinate roma tomato, widely adapted, medium fruits, uniform color, cylindrical shape, deep-red color, excellent firmness, medium to large vigorous plant, good fruit cover, sets well in hot temperatures. Adaptation: widespread. Resistance: Verticillium wilt race 1, Fusarium wilt races 1 and 2, gray leaf spot, alternaria stem canker, TSWV
Plum Crimson-Breeder: North Carolina State University. Vendor: HMClause. Parentage: F1 hybrid of NC EBR-7 $\times$ NC EBR-8. Characteristics: Plum tomato for vine ripe/ mature green harvest production, early maturity, medium tall determinate plant with dark green foliage, large fruit with uniform shape, resistant to fruit cracking and graywall, good exterior and interior color (homozygous crimson), susceptible to bacterial spot, not adapted to high temperature fruit set. Resistance: Fusarium wilt races 1, 2, and 3 , Verticillium wilt race 1 , moderate early blight resistance. HortScience 41:259-260. 2002.

Plum Regal (NC 05255) - Breeder: North Carolina State University. Vendor: Bejo Seeds. Parentage: F1 hybrid of NC $30 \mathrm{P} \times \mathrm{NC}$ 25P. Characteristics: Plum tomato for fresh market, vine ripe/mature green harvest, late season maturity, large, crack resistant, good shape, excellent interior color (homozygous crimson), not adapted to hot season production. Resistance: Fusarium wilt races 1 and 2, Verticillium wilt race 1, tomato spotted wilt virus, late blight (heterozygous $\mathrm{Ph}-3$ gene), tomato spotted wilt virus, moderate bacterial spot resistance. HortScience 45:824-825. 2008.

Quincy (XP 01408383) - Breeder and vendor: Seminis Vegetable Seeds-Asgrow. Parentage: F1 hybrid. Characteristics: fresh market type; tall, determinate produces large and extra-large, deep oblate, uniformly colored fruit; firmness and quality are good; fruit has jointed pedicles; maturity is late. Similar: Florida 47, BHN 444, BHN 640. Adaptation: NAFTA; southeast U.S. and Argentina. 2004.

Reba-Breeder and vendor: Sakata Seed America, Inc. Characteristics: Determinate round, strong plant with large, high quality globe shaped fruit. Resistance: Verticillium wilt race 1, Fusarium wilt races 1, 2, alternaria stem canker, gray leaf spot. Similar: Shady Lady. Adaptation: ground culture, California, early season. 2006.

Red Delight - Breeder and vendor: Sakata Seed America, Inc. Parentage: hybrid. Characteristics: high-yielding; round; produces a high percentage of firm, extra-large fruit with excellent color. Resistance: Verticillium wilt race 1, Fusarium wilt races 1 and 2, alternaria stem canker; tolerant to gray leaf spot. Adaptation: Florida and Eastern U.S. 2005.

Red Grape-Breeder and vendor: D. Palmer Seed Co., Inc. Parentage: hybrid. Characteristics: indeterminate grape shaped tomato; good leaf cover; bright red fruit; excellent for bite-size eating; fruit are consistent and firm; one of the top varieties on the market today; can be grown in the open field or the greenhouse. 2005.

Red Pearl-Breeder and vendor: Johnny's Selected Seeds. Characteristics: early, fresh market. Fruit oblong cherry ("grape"), red, thin skin, green shoulder, flavorful, good shelf life, avg. 15-20 g. Indeterminate. Resistance: Fusarium wilt races 1 and 2, early blight (horizontal), late blight (horizontal.) Similar: Santa. Adaptation: wide. PVP. 2010.

Rubia-Breeder and vendor: Sakata Seed America, Inc. Characteristics: Determinate saladette, vigorous, large plant with high quality, medium-large, smooth fruit. Resistance: Verticillium wilt race 1, Fusarium wilt races 1 and 2, alternaria stem canker, gray leaf spot, tomato spotted wilt virus, tomato yellow leaf curl virus. Adaptation: Florida, Central America. 2010.

Samurai-Breeder and vendor: Harris Moran Seed Co. Parentage: F1 hybrid. Characteristics: Plum type. Resistance: Fusarium (race 3). Similar: Saladette, Roma. Adaptation: U.S. 2003.

Scala (RS 1652297) - Breeder and vendor: Seminis Vegetable Seeds-Royal Sluis. Characteristics: medium size, medium to good firmness, round to high-round shape, internodes somewhat long, indeterminate vine, nice green to red color with good uniformity, strong plant, good coverage, large fruits $(230 \mathrm{~g})$, beautiful red color fruit when ripe. Resistance: Fusarium wilt races 1 and 2, tomato mosaic (strain 0-2), Verticillium wilt race 1, tomato yellow leaf curl virus. Similar: Daniela. Adaptation: Brazil. 2002.

Sebring - Breeder: University of Florida and Syngenta Seeds. Vendor: Syngenta Seeds, Inc./Rogers Brand. Parentage: hybrid. Characteristics: main season, determinate stake beef tomato; offers extra-large to large fruit with uniform green shoulders. Resistance: Fusarium wilt races 1, 2, and 3, Fusarium crown rot, Verticillium wilt race 1, gray leaf spot. Adaptation: the East. 2005. 
Smarty-Breeder: North Carolina State University. Vendor: HMClause. Parentage: F1 hybrid of NC3 grape $\times$ NC 2 grape. Characteristics: Fresh market grape tomato hybrid, early maturity, very compact indeterminate plant (homozygous brachytic gene), requires heavy pruning below first flower cluster when trellised, high sugar, firm, crack resistant, extended shelf life rin hybrid, good exterior and interior color, free of yellow shoulder, uniform green color (u gene) of immature fruit. Resistance: Fusarium wilt race 1, Verticillium wilt race 1, tolerant to early blight and bacterial spot. HortScience 45: 1887-1888. 2005.

Solar Fire (Fla. 7943B) - Breeder: University of Florida. Vendor: HMClause Seed Co. Parentage: $F_{1}$ hybrid of Fla. $7946 \times$ Fla. 7776. Characteristics: Fresh market type for mature green harvest, determinate vine, early to mid-season, heat-tolerant fruit set, fruit are medium-large, firm, light-green shoulders, smooth blossom scars. Resistance: Fusarium wilt races 1, 2, and 3, Verticillium wilt race 1, gray leaf spot. Adaptation: Florida and southeast US. HortScience 41:1504-1505. 2004

Solid Gold-Breeder and vendor: Sakata Seed America, Inc. Characteristics: Indeterminate grape, golden fruit color with excellent flavor, mid-early maturity, $12-15 \mathrm{~g}$. Resistance: Fusarium wilt race 1. 2009.

St. Nick-Breeder and vendor: Siegers Seed. Parentage: Hybrid. Characteristics: Grape tomato that is a beautiful oblong hybrid. St. Nick weighs only 12 to $15 \mathrm{~g}$ with $8 \%$ to $10 \%$ sugar content (brix). Clusters of up to 50 green-shouldered fruit are possible and firm on its indeterminate plant type. It is brilliant-red and delicious.

Styllus (145394) - Breeder and vendor: Seminis Vegetable Seeds-Horticeres. Parentage: F1 hybrid. Characteristics: fresh market type, LSL, high yield potential, short internodes and good vigor; fruit are very firm, round flat, small green shoulder, shiny red at maturity. Resistance: Verticillium wilt race 1, tomato yellow leaf curl virus, nematodes, Fusarium wilt races 1 and 2), tomato mosaic virus. Similar: Daniella, Gabriella. Adaptation: Brazil. 2003.

Sun King (XP 150410) — Vendor: Seminis Vegetable SeedsAsgrow. Parentage: F1 hybrid. Characteristics: large, vigorous, determinate plant; large to extra large, deep oblate fruit; uniform green, normal ripening. Resistance: Fusarium wilt races 1 and 2, alternaira stem canker, gray leaf spot; Verticillium wilt race 1. Similar: Shady Lady. Adaptation: California. 2002.

Sweet Canary-Breeder and vendor: Sakata Seed America, Inc. Characteristics: Determinate grape, yellow fruit color, 14-15 g, firm fruit. Resistance: none. Adaptation: indoor and outdoor culture. 2010.

Sweet Elite-Breeder and vendor: Sakata Seed America, Inc. Characteristics: Indeterminate grape, larger fruit size (15-20 g) than standard grapes (10-12 g), good fruit set in cooler conditions, good flavor and resistance to fruit cracking. Resistances: Fusarium wilt races 1 and 2, gray leaf spot, leaf mold races $\mathrm{A}-\mathrm{C}$, tomato mosaic virus races 0-2. Adaptation: winter cycle production. 2010.

Sweet Hearts - Breeder and vendor: Sakata Seed America, Inc. Characteristics: grape tomato; brilliant red and very uniform in shape with excellent flavor and good resistance to cracking; indeterminate plants produce very impressive yields with continuous sets and full clusters to the top of the plant; very sweet with high Brix; excellent shelflife. 2005.

Sweet Zen-Breeder and vendor: Sakata Seed America, Inc. Characteristics: Determinate grape, red color, early maturity, good brix, heat tolerant, extended harvest, firm fruit that ships well. Resistance: none. Adaptation: indoor and outdoor. 2010.

Tachi-Breeder and vendor: Sakata Seed America, Inc. Characteristics: Determinate saladette, compact plant with large to extralarge fruit, heavy set. Resistance: Verticillium wilt race 1, Fusarium wilt races 1 and 2, alternaria stem canker, gray leaf spot, nematodes, tomato spotted wilt virus. Similar: Mariana. Adaptation: wide, staked and ground culture. 2011.

Tasti-Lee $^{\text {TM }}$ (Fla. 8153) - Breeder: University of Florida. Vendor: Bejo Seeds. Parentage $F_{1}$ hybrid of Fla. $8059 \times$ Fla. 7907 Characteristics: Fresh market type for premium vine ripe harvest, determinate, jointed pedicels, early to mid-season maturity with moderate heat-tolerance, fruit are small to large flat-round, firm, crimson $\left(\operatorname{og}^{c}\right)$ fruit with good flavor, light green shoulders, good crack resistance, stellate blossom scars. Resistance: Fusarium wilt races 1, 2, and 3, Verticillium wilt race 1, gray leaf spot. Adaptation: wide - entire east coast and California. HortScience 43:2228-2230. 2006.

Taxi-Breeder and vendor: Johnny's Selected Seeds. Characteristics: early, local fresh market. Fruit semi-oblate, medium soft, 3-5 locule, yellow (rrTT), uniform ripening, avg. 115 g. Compact determinate. Adaptation: temperate. 1986

Tough Boy 93-Breeder and vendor: American Takii, Inc. Characteristics: medium-early, deep-oblate shaped fresh market pink tomato; excellent flavor and high sugar content. Resistance: tomato mosaic virus, Verticillium wilt, Fusarium wilt races 1 and 2, gray leaf spot, intermediate resistance to bacterial wilt. 2005 .

Traci (HA 3209) - Breeder and vendor: Hazera Seeds Inc. Characteristics: indeterminate beef tomato for greenhouse production; produces globe-shape fruit that weigh between 9 and $10 \mathrm{oz}$; mid-maturing tomato with high yields; firm fruit; intense red color. Resistance: Verticillium wilt race 1, Fusarium wilt races 1 and 2, tobacco mosaic virus, and tomato yellow leaf curl virus. 2005.

Tribeca (Fla. 8363) - Breeder: University of Florida. Vendor: Vilmorin Seed Co. Parentage: $F_{1}$ hybrid of Fla. $8249 \times$ Fla. $8124 C$. Characteristics: Fresh market type for mature green harvest, determinate vine, jointed pedicels, fruit are medium to large, early season with moderate heat-tolerance, firm fruit with light green shoulders and nipple blossom scars $(n-4 /+)$, Resistance: Fusarium wilt races 1 and 2, Verticillium wilt race 1 , gray leaf spot, tomato spotted wilt virus. Adaptation: Southeastern US and Florida but not for winter production in South Florida. HortScience 44:471-473. 2007.

Tribute-Breeder and vendor: Sakata Seed America, Inc. Characteristics: Determinate round, medium to large, globe shaped fruit, early maturity, good hot set. Resistance: Verticillium wilt race 1, Fusarium wilt races 1 and 2, alternaria stem canker, gray leaf spot, tomato yellow leaf curl virus, tomato Spotted Wilt Virus. Adaptation: Eastern US. 2009

Tygress (XP 1432427) - Breeder and vendor: Seminis Vegetable Seeds-Asgrow. Parentage: F1 hybrid. Characteristics: fresh market type; vigorous, determinate plant, superior yield and quality for main season planting; smooth uniform green fruit with deep oblate shape; quality similar to Florida 47; superior yield and quality in early plantings with virus protection. Resistance: alternaria stem canker, Verticillium wilt race 1; Fusarium wilt races 1 and 2; gray leaf spot; tomato mosaic virus, tomato yellow leaf curl virus. Similar: Florida 47. Adaptation: Florida. 2003.

Veloz (PS 01512626) - Breeder and vendor: Seminis. Parentage: F1 hybrid. Characteristics: fresh market type, early maturing, determinate saladette with a high yield and high quality smooth, extra large egg-shaped fruit which are firm with a brilliant red exterior and interior color. Resistance: Verticillium wilt race 1, Fusarium wilt race 1, nematodes, tomato mosaic virus (strain 0-2), alternaria stem canker, tomato spotted wilt virus. Similar: Toro, Moiica, Yaqui. Adaptation: NAFTA-Mexico, California. 2005.

\section{TURNIP}

STG 6903 - Breeder: Sakata Seed. Vendor: Siegers Seed. Parentage: Hybrid. Characteristics: Tall hybrid turnip with heavyweight leaves that display very rapid and early regrowth. Its heavy leaves are very dark green, glossy, and smooth. It matures early with small short roots, and has good bolt resistance.

\section{WATERMELON}

\section{Tammy L. Ellington and Todd C. Wehner \\ Department of Horticultural Science North Carolina State University Raleigh, NC 27695-7609}

401 Seedless - Vendor: Seed Way. Parentage: Triploid. Characteristics: 85 days to maturity; 16-18 lb; round, oval; light green rind 
with mottled dark green stripes; moderate resistance to Fusarium 1 and anthracnose 1; very strong vines and uniform yields. Adaptation: U.S. 2005.

402 Seedless-Vendor: Seed Way. Parentage: hybrid triploid. Characteristics: 86 days to maturity; $14-16 \mathrm{lb}$; round; black rind with stripe; bright red flesh; not prone to hollowheart. Adaptation: U.S. 2005.

4502 Seedless - Vendor: Seed Way. Parentage: Triploid. Characteristics: 84 days to maturity; $6-8 \mathrm{~kg}$; oval; bright red flesh. Adaptation: U.S. 2005.

Ace of Hearts - Vendor: Petoseed, DeWitt Seed. Parentage: Hybrid triploid. Characteristics: 82-87 days to maturity; 7-10 kg; oblong; green rind with medium green stripes; bright red flesh; excellent shipper. Adaptation: U.S. 2002.

Aladdin 238-Vendor: Chia Tai Company. Parentage: hybrid diploid. Characteristics: $70-75$ days to maturity; 4-6 kg; round; dark green rind; yellow flesh; 11\% sugar. Adaptation: U.S. 2002.

Alaska 314 -Vendor: Chia Tai Company. Parentage: hybrid diploid. Characteristics: 60-65 days to maturity; 5-7 kg; oblong; dark green rind with stripes; red flesh; $12 \%$ sugar; small seed; easy harvest. Adaptation: U.S. 2002.

Amarillo-Breeder: T. Williams. Vendor: Syngenta Seeds. Parentage: triploid seedless F1 hybrid. Characteristics: yellow fleshed, globe shaped fruit; striped medium green rind; fruit weight 12-14 lb; very sweet; early maturity (80 days). Similar: Buttercup. Adaptation: U.S. 2001.

Anthem-Vendor: Seed Way. Parentage: hybrid diploid. Characteristics: 84 days to maturity; 20-24 lb; oval; light green rind with mottled, dark green stripes; bright red flesh; moderate resistance to Fusarium race 1 and anthracnose. Adaptation: U.S. 2005.

Apollo (PS 11052889) — Breeder and vendor: Seminis Vegetable Seeds. Parentage: triploid F1 hybrid. Characteristics: early, uniform, large Tri-X type seedless watermelon; fruit are oval shaped, 18-20 lb rind has a dark green stripe on a light green background; firm red flesh; small pip size; good fruit setting ability. Similar: Millionaire, Tri-X. Adaptation: NAFTA, Southeast U.S., Mexico. 2004.

Arriba!-Vendor: Hollar Seeds; Seedway. Parentage: hybrid diploid. Characteristics: 82 days to maturity; 11-12 kg; blocky oblong; light green rind with green stripes; bright to medium red fruit; tolerant to some races of Fusarium and anthracnose; similar to Royal Sweet. Adaptation: U.S. 2002.

Asahi-Miyako - Vendor: Takii Seed. Parentage: hybrid diploid. Characteristics: $1 \mathrm{~kg}$; round; medium green rind with black stripes; red flesh; not long distance transporter. Adaptation: U.S. 2002.

Athens - Vendor: Sunseeds. Parentage: hybrid diploid. Characteristics: early maturity; vigorous vine; $22-28 \mathrm{lb}$; long/blocky; dark green wide stripes on light green background; similar to Sangria \& Allsweet; tolerant to Fusarium race 1; good shipper; resistant to hollowheart. Adaptation: U.S. 2002.

Atommic 517-Vendor: Chia Tai Company. Parentage: hybrid diploid. Characteristics: 55-60 days to maturity; 2-4 kg; round; black rind; dark red flesh; 13\% sugar. Adaptation: U.S. 2002.

Augustina 113 - Vendor: Chia Tai Company. Parentage: hybrid diploid. Characteristics: 80 days to maturity; $6-8 \mathrm{~kg}$; short oblong; light green rind with dark green stripes; red flesh; 11\% sugar; vigorous vine; small seed. Adaptation: U.S. 2002.

Baby Doll-Vendor: Rupp Seeds. Parentage: hybrid diploid. Characteristics: 70 days to maturity; $5-7 \mathrm{~kg}$; oval; medium green rind with dark green stripes; bright yellow flesh; excellent for market and shipping. Adaptation: U.S. 2002.

Banner (SXW 0037) — Vendor: Stokes; Siegers Seed Co. Parentage: hybrid diploid. Characteristics: 85 days to maturity; $12 \mathrm{~kg}$; elongated; wide dark stripes; red flesh; tolerant to Fusarium race 1. Adaptation: U.S. 2002

Banphai 999-Vendor: Chia Tai Company. Parentage: hybrid diploid. Characteristics: $70-75$ days to maturity; $2-4 \mathrm{~kg}$; short oblong; light green rind with dark green stripes; red flesh; $12 \%$ sugar; crisp and sweet; small seeds. Adaptation: U.S. 2002.

Baron-Vendor: Stokes. Parentage: hybrid diploid. Characteristics: 88 days to maturity; $8-10 \mathrm{~kg}$; elongated; dark green rind; dark red flesh; local markets. Adaptation: U.S. 2002.
Big Black 935 - Vendor: Chia Tai Company. Parentage: hybrid diploid. Characteristics: 70-75 days to maturity; 4-6 kg; round; black rind; bright red flesh; $11 \%$ sugar; crisp flesh. Adaptation: U.S. 2002.

Big Charlie - Vendor: D.V. Burrell Seed Co; D.Palmer Seed Co; Zeraim Gedera Ltd. Characteristics: $8-11 \mathrm{~kg}$; oval shaped. Adaptation: U.S. 2002.

Big Crimson-Vendor: Willhite. Parentage: open-pollinated. Characteristics: 85 days to maturity; $14 \mathrm{~kg}$; round; small broken dark green stripes over light green rind; crimson red flesh; tolerant to A-1, F-1; crisp flesh; very sweet; long distance shipper. Adaptation: U.S. 2002.

Big Magic 511 — Vendor: Chia Tai Company. Parentage: hybrid diploid. Characteristics: 55-60 days to maturity; $2-4 \mathrm{~kg}$; high round; black rind; red flesh; 11\% sugar; long shipping; high yield. Adaptation: U.S. 2002.

Big Stripe - Vendor: Willhite; DeWitt Seed. Parentage: hybrid diploid. Characteristics: 85 days to maturity; $14 \mathrm{~kg}$; oblong; light green rind with dark green stripes; red flesh; tolerant to Fusarium wilt; good shipper. Adaptation: U.S. 2002.

Big Tiger 407-Vendor: Chia Tai Company. Parentage: hybrid diploid. Characteristics: 60-65 days to maturity; 7-9 kg; oblong; light green rind with stripes; pink-red flesh; 11\% sugar; easy setting; big fruit. Adaptation: U.S. 2002.

Blacktail Mountain-Vendor: Seed Savers Exchange. Characteristics: 76 days to maturity; round; 6-12 lb; dark green rind patterned with narrow darker green stripes; sweet orange-red flesh; very reliable crops. Adaptation: U.S. 2003.

Bobby - Vendor: Seed Way. Parentage: hybrid triploid. Characteristics: 84 days to maturity; $6-8 \mathrm{lb}$; round; medium green rind with narrow dark stripes; deep red flesh; high sugars; Jubilee stripe. Adaptation: U.S. 2005

Boston-Vendor: Sunseed. Parentage: hybrid triploid. Characteristics: 14-18 lb; round/oval; indistinct narrow dark green stripes on light green background; red flesh; $11 \%$ sugar; tolerant to Fusarium wilt race 1; resistant to hollowheart; good shipper. Adaptation: U.S. 2002.

Bravo - Vendor: Hollar Seeds. Parentage: hybrid diploid. Characteristics: 87 days to maturity; $10-12 \mathrm{~kg}$; elongated; dark green broken light green stripes; dark red flesh; tolerant to some races of Fusarium and anthracnose; compare to Sangria. Adaptation: U.S. 2002.

Butterball-Breeder and vendor: D. Palmer Seed Co. Parentage: triploid F1 hybrid. Characteristics: seedless type with canary yellow flesh that is crisp and firm; very high yield; oval fruit shape; $15-18 \mathrm{lb}$ fruit weight; narrow stripe on light green background; good shipper. Resistance: Fusarium wilt. Adaptation: U.S. 2002.

Cadiz-Vendor: Hollar Seeds. Parentage: open-pollinated. Characteristics: 82 days to maturity; 2-3 kg; blocky oblong; green stripe on light green background; medium red flesh. Adaptation: U.S. 2002.

Campeche (SSC 1083)-Breeder: Qualiveg Seed Production. Vendor: Shamrock Seed Co. Parentage: F1 diploid hybrid. Characteristics: widely adapted; Allsweet rind pattern; vines with abundant foliage and broad leaves for fruit protection; fruit has an elongated shape with a 24-lb average weight (larger girth than standard Allsweet); bright red flesh and high sugars enhance its overall internal quality; matures in 80-90 days and offers high yields over a long season. Resistance: Fusarium wilt (race 1) and anthracnose. Similar: Sangria. Adaptation: all watermelon growing regions. 2002.

Canada Supersweet-Vendor: Stokes. Parentage: hybrid diploid. Characteristics: 70 days to maturity; $10 \mathrm{~kg}$; oblong; light green rind with contrasting dark stripes; tolerant to Fusarium race 1; good shipper. Adaptation: U.S. 2002.

Carson-Vendor: Seed Way. Parentage: hybrid diploid. Characteristics: 85 days to maturity; $15-18 \mathrm{lb}$; elongated; medium green rind with dark green, broad mottled stripes; bright red flesh; fade resistant rind with large leaves; excellent pollinator; moderate resistance to Fusarium 0,1 and anthracnose. Adaptation: U.S. 2005.

Celebration-Breeder: T. Williams. Vendor: Syngenta Seeds. Parentage: diploid seeded F1 hybrid. Characteristics: Allsweet type; large (21-26 lb) blocky fruit; early, mid-season maturity (84 days). Resistance: Fusarium wilt races 0, 1; anthracnose race 1. Similar: Summer Flavor 800. 1999. 
Cha Cha Cha (SSC 31829) - Breeder and vendor: Shamrock Seed Co. Parentage: F1 triploid hybrid. Characteristics: seedless; consistent yield and quality over a wide range of production regions and growing conditions; strong vines produce oval shaped fruit weighing 17-19 lb; rind is dark green with narrow, light green stripes; fruit has very sweet, bright red flesh and excellent rind demarcation; 75 days from transplant to harvest. Resistance: none claimed. Similar: Summer Sweet 5244. Adaptation: U.S. 2003.

Charlene-Vendor: Willhite Seed Inc. Parentage: hybrid. Characteristics: $80-85$ days to maturity; blocky; $22-25 \mathrm{lb}$; tough rind; sweet red flesh; excellent shipper; tolerant to Fusarium wilt; very productive. Adaptation: U.S. 2003.

Chiffon F1-Vendor: Harris Seeds. Parentage: open-pollinated. Characteristics: 80 days to maturity; $4-7 \mathrm{~kg}$; nearly round; light green with dark green stripes; bright yellow seedless flesh; local market. Adaptation: U.S. 2002.

Christina 173 - Vendor: Chia Tai Company. Parentage: hybrid diploid. Characteristics: $80-85$ days to maturity; 7-9 kg; short oblong; light green rind; red flesh; $11 \%$ sugar; very vigorous; highly productive. Adaptation: U.S. 2002.

Chubby Gray-Vendor: Willhite. Parentage: open-pollinated. Characteristics: 90 days to maturity; $12-14 \mathrm{~kg}$; short blocky; graygreen thick rind; red firm flesh; good shipper. Adaptation: U.S. 2002.

Cobb Gem-Vendor: Willhite; Gurney's. Parentage: openpollinated. Characteristics: 100 days to maturity; $59 \mathrm{~kg}$; large; dark green rind with light green stripes; red flesh; show melons. Adaptation: U.S. 2002.

Colorado Sunset-Vendor: D.V. Burrell Seed Growers Co. Parentage: hybrid. Characteristics: 85 days to maturity; oblong; 20-22 lb; rind pattern similar to Allsweet; bright orange flesh; tolerant to Fusarium wilt; good for commercial production and roadside markets. Adaptation: U.S. 2002.

Companion (PS 11006741)-Breeder and vendor: Seminis Vegetable Seeds-Petoseed. Parentage: diploid open pollinated. Characteristics: small dwarf plant, compact, round gray fruit, 2-3 kg in size. Similar: none. Adaptation: North America, Mexico. 2002.

Constitution (SXW 3053) - Vendor: Stokes; Sunseeds. Parentage: hybrid triploid. Characteristics: 80 days to maturity; $7 \mathrm{~kg}$; oval/ round; dark green stripes on medium green background; dark red flesh; 12\% sugar; tolerant to Fusarium race 1 and hollowheart. Adaptation: U.S. 2002.

Cordoba-Vendor: Hollar Seeds. Parentage: open-pollinated. Characteristics: 84 days to maturity; $2-3 \mathrm{~kg}$; elongated fruit; dark green stripe on green; medium red. Adaptation: U.S. 2002.

Cotton Candy - Vendor: Harris Seeds. Parentage: hybrid triploid. Characteristics: $80-85$ days to maturity; $6-9 \mathrm{~kg}$; round; light green rind with dark green stripes; pink-red fruit. Adaptation: U.S. 2002.

Cream of Saskatchewan-Vendor: Eastern Native Seed Conservancy. Parentage: open-pollinated. Characteristics: 2-6 kg; round; white to creamy flesh; outstanding sweetness and flavor; thin rind. Adaptation: U.S. 2002.

Crestone-Vendor: D.V. Burrell Seed Growers Co. Parentage: hybrid. Characteristics: 80 days to maturity; blocky/oblong; rind similar to Crimson Sweet; red flesh; 22-24 lb; tolerance to Fusarium; good for commercial production and roadside market. Adaptation: U.S. 2005.

Crimson Delight - Vendor: Hollar Seeds. Parentage: hybrid diploid. Characteristics: 79 days to maturity; 10-12 kg; globular and round; green stripe on light green rind; medium red fruit; tolerant to some races of Fusarium and anthracnose. Adaptation: U.S. 2002.

Crimson Jewel-Vendor: Seed Way; Abbott \& Cobb; Sakata. Parentage: hybrid diploid. Characteristics: 83 days to maturity; 4-7 $\mathrm{kg}$; oval; medium green broad green stripes; rosy red fruit; tolerant to Fusarium race 1, AN-1 (T). Adaptation: U.S. 2002.

Crisp N Sweet-Vendor: Zeriam Gedera Seed Co. Parentage: hybrid triploid. Characteristics: 83 days to maturity; 16-20 lb; oval; bright red flesh; vigorous. Adaptation: U.S. 2005.

CT Dollar 034 - Vendor: Chia Tai Company. Parentage: hybrid diploid. Characteristics: 70 days to maturity; 6-8 kg; round; dark green rind; bright red flesh; $11 \%$ sugar; high yields; good shipper. Adaptation: U.S. 2002.
Daytona-Breeder and vendor: Sakata Seed America, Inc. Parentage: hybrid diploid. Characteristics: 83 days to maturity; very attractive All Sweet type; weighs 22 to 26 lb; oval; blocky, oblong; light green rind with wide, mottled, dark green stripes; bright red flesh and medium to small black seeds; heavy yielder; dark exterior. Adaptation: U.S. 2005.

Delta 4-Vendor: Golden Valley. Parentage: F1 triploid hybrid. Characteristics: mini-seedless type; round oval fruit shape; medium green background, dark green stripes; 85 days to maturity; crisp sweet interior; excellent shipper. Adaptation: U.S. 2004.

Deluxe 166-Vendor: Chia Tai Company. Parentage: hybrid triploid. Characteristics: $75-80$ days to maturity; 4-6 kg; round; dark green with stripes; red flesh; 12\% sugar; high yield; disease tolerant. Adaptation: U.S. 2002.

Desert King-Vendor: Willhite; Gurney's. Parentage: openpollinated. Characteristics: 85 days to maturity; round to slightly oblong; light pea green rind; deep rich yellow flesh; will not sunburn; drought tolerant; tough enough to stand hauling well. Adaptation: U.S. 2002.

Desert Storm —Vendor: Willhite; DeWitt Seed; Abbott \& Cobb; Siegers Seed. Parentage: hybrid diploid. Characteristics: 80-85 days to maturity; $10-12 \mathrm{~kg}$; oblong; medium green rind with dark green stripes; red flesh; tolerant to Fusarium wilt; good shipper. Adaptation: U.S. 2002.

Deuce of Hearts-Vendor: PS Petoseed; DeWitt Seed. Parentage: hybrid triploid. Characteristics: $80-85$ days to maturity; $4-7 \mathrm{~kg}$; round; light green rind with dark green stripes; firm, red flesh; good foliage cover; very productive. Adaptation: U.S. 2002.

Diamond-Vendor: Hollar Seeds. Parentage: hybrid triploid. Characteristics: 87 days to maturity; $5-7 \mathrm{~kg}$; globular; green stripe on light green; medium red flesh; some tolerance to anthracnose; compare to AC5244. Adaptation: U.S. 2002.

Diana 179-Vendor: Chia Tai Company. Parentage: hybrid diploid. Characteristics: 80 days to maturity; 7-9 kg; short oblong; light green with dark stripes; red flesh; $11 \%$ sugar; vigorous; disease tolerant; good shipper. Adaptation: U.S. 2002.

Dillon (HA-5005) - Breeder and vendor: Hazera Seeds. Parentage: F1 triploid hybrid. Characteristics: seedless; round to oval fruit shape; light-green rind with green stripes, and an average weight of 18 to $20 \mathrm{lb}$; uniform dark red flesh is very sweet. 2001 .

Disko (EMR32) - Vendor: Johnny's; Hazera. Parentage: hybrid triploid. Characteristics: 75 days to maturity; 7-12 kg; round oval; dark green cloudy wide stripes on light green; pink-red flesh; $11 \%$ sugar; tolerant to F1; excellent flavor. Adaptation: U.S. 2002.

Dulce-Vendor: Willhite Seed Inc. Parentage: hybrid. Characteristics: 85 days to maturity; oblong; slightly smoky cast to the rind; firm red flesh; tolerant to Fusarium wilt; $24-26 \mathrm{lb}$; very productive. Adaptation: U.S. 2003

Early Moonbeam-Vendor: Fedco Seeds. Parentage: openpollinated. Characteristics: 78 days to maturity; $2-3 \mathrm{~kg}$; dark green stripes on light green; yellow flesh. Adaptation: U.S. 2002.

Early Star-Vendor: PS Petoseed. Parentage: hybrid diploid. Characteristics: 72 days to maturity; $4-5 \mathrm{~kg}$; round; dark green thin rind; rich red crisp flesh; tolerant to F1; early sugar baby type hybrid for greenhouse. Adaptation: U.S. 2002.

Emerald (EMR27) - Vendor: Hazera. Parentage: hybrid triploid. Characteristics: 85 days to maturity; $6-10 \mathrm{~kg}$; round; light green with dark green stripes; red flesh; 11\% sugar; excellent flavor. Adaptation: U.S. 2002.

Emperor-Vendor: PS Petoseed; Stokes. Parentage: hybrid diploid. Characteristics: 84 days to maturity; 9-11 kg; oblong; medium green with thin stripes; bright red crisp flesh; tolerant to F1; early; good shipper. Adaptation: U.S. 2002.

EMR1032 - Vendor: Hazera. Parentage: hybrid diploid. Characteristics: 85 days to maturity; 7-11 kg; oval; light green with green stripes; dark red flesh; 12\% sugar; good shelflife. Adaptation: U.S. 2002.

Extazy (HA 6008) - Breeder and vendor: Hazera Seeds Inc. Parentage: hybrid triploid. Characteristics: very popular, mini (or personal) seedless watermelon boasting a dark green rind with light green stripes; 5-7 lb; when sliced, it has a thin rind and brilliant red 
flesh; early maturing (84 days); has produced exceptional yields in open field production. Adaptation: U.S. 2005.

Falcon704-Vendor: Chia Tai Company. Parentage: hybrid diploid. Characteristics: $70-75$ days to maturity; 5-8 kg; round; light green rind with dark green stripes; bright red flesh; $12 \%$ sugar; firm sweet flesh; small seed. Adaptation: U.S. 2002.

Fancy174-Vendor: Chia Tai Company. Parentage: hybrid diploid. Characteristics: $75-80$ days to maturity; $6-8 \mathrm{~kg}$; round; dark green rind with stripes; red flesh; 11\% sugar; crisp flesh. Adaptation: U.S. 2002.

Favor C3-Vendor: Chia Tai Company. Parentage: open-pollinated. Characteristics: 70-75 days to maturity; 1-2 kg; oblong; green rind with stripes; bright red flesh; 12\% sugar. Adaptation: U.S. 2002.

Freedom-Breeder and vendor: Sunseeds Co. Characteristics: elongated variety; deep red interior color; high sugar content; attractive outer appearance; good shipping ability; improved shelflife; early maturing triploid that has a Jubilee-type rind pattern; vigorous vine produces high yields of fruit weighing in between 16 and $20 \mathrm{lb}$; high interior fruit quality; small seed traces. Resistance: resistance/tolerance to Fusarium wilt race 1. 2005.

Festival-Vendor: Johnny's. Parentage: open-pollinated. Characteristics: 75 days to maturity; round; deep green rind with black stripes; red flesh; tolerant to F1. Adaptation: U.S. 2002.

Fire Ball 203 - Vendor: Chia Tai Company. Parentage: hybrid diploid. Characteristics: 75 days to maturity; 5-7 kg; short oblong; green rind with stripes; red flesh; 12\% sugar; vigorous; high fruit setting; very sweet. Adaptation: U.S. 2002.

Firecracker-Vendor: Orsetti Seed Co. Parentage: hybrid triploid. Characteristics: 83 days to maturity; round; globe shaped fruit; green rind with dark green stripes; brilliant crisp red flesh; 20-22 lb; $12 \%$ sugar content; excellent long distance shipper; adapted to southwestern US; seedless. Adaptation: U.S. 2005.

First Class 748 - Vendor: Chia Tai Company. Parentage: hybrid diploid. Characteristics: 70-75 days to maturity; 5-8 kg; short oblong; light green rind with dark green stripes; red flesh; $13 \%$ sugar; uniform; crisp flesh; good shipper. Adaptation: U.S. 2002.

Flamingo 310 - Vendor: Chia Tai Company. Parentage: hybrid diploid. Characteristics: 70-75 days to maturity; 5-7 kg; round; green rind with stripes; red flesh; 11\% sugar; small seed. Adaptation: U.S. 2002.

Flamingo 374-Vendor: Chia Tai Company. Parentage: openpollinated. Characteristics: $70-75$ days to maturity; $1-2 \mathrm{~kg}$; round; green with stripes; red flesh; 12\% sugar. Adaptation: U.S. 2002.

Florida Giant - Characteristics: 14-23 kg; round; smooth thick rind, very dark with bluish cast; bright red flesh; 11\% sugar. Adaptation: U.S. 2002.

Force 347-Vendor: Chia Tai Company. Parentage: hybrid diploid. Characteristics: 70 days to maturity; $3-5 \mathrm{~kg}$; round; yellow rind; red flesh; $10 \%$ sugar; high yields; uniform; small seed. Adaptation: U.S. 2002.

Freedom-Vendor: Sakata; Sunseeds. Parentage: hybrid triploid. Characteristics: $85-90$ days to maturity; 7-10 kg; blocky long; thin dark rind with dark green stripes; red flesh; $11 \%$ sugar; tolerant to F1. Adaptation: U.S. 2002.

Frontier 747-Vendor: Chia Tai Company. Parentage: hybrid diploid. Characteristics: 75-80 days to maturity; 6-9 kg; short oblong; light green rind with dark green stripes; red flesh; $12 \%$ sugar; high fruit set; very sweet crisp flesh. Adaptation: U.S. 2002.

Funbell-Vendor: Henry Field's; Gurney's. Characteristics: 85 days to maturity; $1-2 \mathrm{~kg}$; round; dark green to yellow rind when ripe; red flesh. Adaptation: U.S. 2002.

Garden Baby-Vendor: Johnny's; PS Petoseed. Parentage: openpollinated. Characteristics: 70 days to maturity; $3 \mathrm{~kg}$; round; dark green rind with faint stripes; red flesh; tolerant to F1. Adaptation: U.S. 2002.

Gem Dandy - Parentage: hybrid triploid. Characteristics: 80 days to maturity; 6-7 kg; bright red flesh; $12 \%$ sugar. Adaptation: U.S. 2002.

Gem-Dandy Santrupti-Vendor: Willhite. Parentage: hybrid triploid. Characteristics: 80 days to maturity; $7 \mathrm{~kg}$; almost round; small broken dark green stripes over light green rind; bright red flesh; seedless; tolerant to Fusarium wilt. Adaptation: U.S. 2002.
Glory — Vendor: Takii Seed. Parentage: hybrid diploid. Characteristics: 45 days to maturity; $2-3 \mathrm{~kg}$; light green rind with dark green thin stripes; bright rosy red flesh; $12 \%$ sugar; long distance transportation; recommended for subtropical areas. Adaptation: U.S. 2002

Gold Baby-Vendor: Takii Seed. Parentage: hybrid diploid. Characteristics: early maturity; $0.5 \mathrm{~kg}$; round; medium green with dark green stripes; creamy yellow flesh; not a good transporter. Adaptation: U.S. 2002.

Gold Strike-Vendor: Willhite Seed Inc. Characteristics: 22-25 lb; dark striped rind; orange flesh; tolerant to Fusarium wilt. Adaptation: U.S. 2003.

Golden Crown - Vendor: Harris Seeds; Park Seed. Parentage: hybrid diploid. Characteristics: 70 days to maturity; $1-2 \mathrm{~kg}$; round; dull pale green turning to bright golden; pink-red flesh. Adaptation: U.S. 2002.

Golden Jubilee-Vendor: Southern Exposure Seed Exchange. Characteristics: 90 days to maturity; yellow flesh; long oval shaped fruit; 25-40 lb; thick light green rind with dark green stripes. Adaptation: U.S. 1996.

Granada-Vendor: Hollar. Parentage: open-pollinated. Characteristics: 85 days to maturity; $3 \mathrm{~kg}$; blocky oblong; green stripe on light green rind; gold flesh. Adaptation: U.S. 2002.

Gun 561-Vendor: Chia Tai Company. Parentage: hybrid diploid. Characteristics: $75-80$ days to maturity; $5-8 \mathrm{~kg}$; short oblong; light green rind; red flesh; $11 \%$ sugar; crisp sweet flesh; long shelf-life. Adaptation: U.S. 2002.

Gypsy (HMX 8914) - Breeder: Bill Copes. Vendor: Harris Moran. Parentage: triploid F1 hybrid. Characteristics: an early seedless type with medium round fruit; fruit have a dark striped exterior and red flesh. Adaptation: U.S. 2002.

Gypsy 177-Vendor: Chia Tai Company. Parentage: hybrid diploid. Characteristics: $75-80$ days to maturity; $6-8 \mathrm{~kg}$; roundoval; green with stripes; bright red flesh; $11 \%$ sugar; high yields; large; sweet. Adaptation: U.S. 2002.

HM 7927 (HMX 7927) - Breeder: Robert Schroeder. Vendor: Harris Moran. Parentage: F1 hybrid. Characteristics: very early maturity; strong plant; very high and concentrated yield; fruit are 5-9 kg; rind pattern is a narrow dark green stripe on a light background; flesh is red with small brown seeds. Adaptation: U.S. 2002.

HMX 6910 - Vendor: Harris Moran. Parentage: hybrid triploid. Characteristics: round/oval; narrow dark green stripes on light green rind; red flesh; 11\% sugar. Adaptation: U.S. 2002.

HMX 7927—Vendor: Harris Moran. Parentage: hybrid diploid. Characteristics: early maturity; medium fruit size; large round shape; 11-16 lb; light green rind with thick dark stripes; light red flesh; compare to Crimson Sweet. Adaptation: Central America; Europe; Turkey 2001.

HMX 7928 -Vendor: Harris Moran. Parentage: hybrid triploid. Characteristics: oval/blocky; very dark green stripes on dark green background; red flesh; 12\% sugar. Adaptation: U.S. 2002.

HMX 8911 - Vendor: Harris Moran. Parentage: hybrid triploid. Characteristics: oval; light green stripes on dark green rind; red flesh; 12\% sugar. Adaptation: U.S. 2002.

Honey Heart - Vendor: PS Petoseed; DeWitt Seed. Parentage: hybrid triploid. Characteristics: $0-85$ days to maturity; $3-5 \mathrm{~kg}$; round to slight oval; dark blue-green stripes on gray-green rind; crisp bright yellow sweet flesh; unique for home garden; ideal for carton pack; good shipper. Adaptation: U.S. 2002.

Hopi Red "Kawaynatnga" - Vendor: Native Seeds. Parentage: open-pollinated. Characteristics: $3-5 \mathrm{~kg}$; round to oblong; light and dark green rinds; pink to red flesh; black seeds. Adaptation: U.S. 2002.

Hopi Yello "Siyatko"- - Vendor: Native Seeds. Parentage: openpollinated. Characteristics: $3-5 \mathrm{~kg}$; round to oblong; green stripes; pale orange flesh. Adaptation: U.S. 2002.

Ice Cream-Vendor: Southern Exposure Seed Exchange. Characteristics: 82 days to maturity; 10-1b fruit; pale green rinds lined with green; pink-red flesh; not good shipper due to thin rind. Adaptation: U.S. 2002.

Imagination-Breeder: T. Williams. Vendor: Syngenta Seeds. Parentage: triploid seedless F1 hybrid. Characteristics: Sugar Baby 
type; very dark, solid green rind; bright red flesh; fruit wt. 12-14 lb; mid-early maturity (82 days). Similar: Emerald. 2001.

Imperial-Vendor: Seed Way. Characteristics: 90 days to maturity; 8-13 kg; elongated; dark/light green sawtooth stripes; red flesh; tolerant to Fusarium. Adaptation: U.S. 2002.

Independance - Vendor: Seed Way. Parentage: hybrid triploid. Characteristics: 85 days to maturity; $18-20 \mathrm{lb}$; round, oval; light green rind with mottled dark green stripes; bright red flesh; high sugars. Adaptation: U.S. 2005.

Jack of Hearts-Vendor: Stokes. Parentage: hybrid diploid. Characteristics: 85 days to maturity; $5 \mathrm{~kg}$; oval; light green rind with contrasting dark stripes; blood red flesh. Adaptation: U.S. 2002.

Jamboree-Breeder: T. Williams. Vendor: Syngenta Seeds. Parentage: diploid seeded F1 hybrid. Characteristics: Allsweet type; large (22-27 lb) elongated fruit; dark red flesh; mid-season maturity (85 days). Resistance: Fusarium wilt races 0, 1; anthracnose race 1. Similar: Sangria, Corporal. 2001.

Jube-ette - Vendor: Willhite. Parentage: hybrid. Characteristics: 80 days to maturity; Jubilee type; $22-25 \mathrm{lb}$; sweet, dark red, firm flesh; tolerant to Fusarium wilt. Adaptation: U.S. 2003.

Judo (EMR41) - Vendor: Johnny's; Hazera. Parentage: hybrid triploid. Characteristics: 82 days to maturity; round; dark green stripes on grey-green rind; pink-red flesh; tolerant to F1. Adaptation: U.S. 2002.

Jupiter-Vendor: Takii Seed. Parentage: hybrid diploid. Characteristics: 43 days to maturity; $1 \mathrm{~kg}$; round; dark green rind; deep red flesh; good transporter. Adaptation: U.S. 2002.

King of Hearts-Vendor: PS Petoseed; DeWitt Seed; Gurney's. Parentage: hybrid triploid. Characteristics: $80-85$ days to maturity; 6-9 kg; blocky, slightly oblong; green with medium green stripes; bright red crisp sweet flesh; 11\% sugar; tolerant to A-1; excellent shipper, bin or carton. Adaptation: U.S. 2002.

Ko Gee 308 - Vendor: Chia Tai Company. Parentage: hybrid diploid. Characteristics: $65-70$ days to maturity; 8-11 kg; oblong; light green rind with stripes; red flesh; $12 \%$ sugar; very big fruit. Adaptation: U.S. 2002.

Lady_Breeder: G.W. Elmstrom. Vendor: Sunseeds. Parentage: diploid F1 hybrid. Characteristics: early maturing, compact plant, medium vigor, good leaf coverage, 22-26 lb fruit (28$35 \mathrm{lb}$ in good growing conditions); Allsweet type fruit with wide dark stripe on medium green background and elongate shape; excellent fruit quality; very deep red flesh; tender, very sweet flesh; few, very small seeds. Resistance: Fusarium wilt race 1. Similar: Allsweet. Adaptation: wide; performs well in eastern U.S. 2001

Laurel-Vendor: Seed Way; Siegers Seed Co; Takii Seed. Parentage: hybrid triploid. Characteristics: 90 days to maturity; 9-10 kg; oval; medium green dark stripes; brilliant red flesh; good for distance shipping. Adaptation: U.S. 2002.

Legacy_-Vendor: Willhite. Parentage: open-pollinated. Characteristics: 85 days to maturity; $10-12 \mathrm{~kg}$; oblong; dark green striped rind; deep red firm flesh; tolerant to wilt; excellent shipper. Adaptation: U.S. 2002.

Liliput (SW1) - Vendor: Hazera. Parentage: hybrid triploid. Characteristics: 70 days to maturity; $1.5-2.5 \mathrm{~kg}$; oval; very dark green rind; red flesh; $11 \%$ sugar; adopted to high planting density. Adaptation: U.S. 2002.

Long Crimson-Vendor: Willhite. Parentage: open-pollinated. Characteristics: $80-85$ days to maturity; $11-13 \mathrm{~kg}$; thick blocky; small broken dark green stripes over light green; red crisp flesh; good shipper. Adaptation: U.S. 2002.

Louisiana Sweet-Vendor: Willhite. Parentage: open-pollinated. Characteristics: 90 days to maturity; 10-14 kg; round oblong; medium green with dark green stripes; brilliant red flesh; tolerant to anthracnose, wilt. Adaptation: U.S. 2002.

Loyalty - Vendor: Takii Seed. Parentage: hybrid diploid. Characteristics: 46 days to maturity; $2 \mathrm{~kg}$; oblong; dark green rind; bright red flesh; good transporter. Adaptation: U.S. 2002.

Lucky Sweet-Vendor: Takii Seed. Parentage: hybrid diploid. Characteristics: $1 \mathrm{~kg}$; round; deep green rind with black stripes; vivid red; good transporter. Adaptation: U.S. 2002.
Majestic (XP 4510759) - Breeder and vendor: Seminis Vegetable Seeds-Asgrow. Parentage: triploid F1 hybrid. Characteristics: seedless Tri-X-313 type; oblong blocky shaped fruit are mediumlarge, $6-8 \mathrm{~kg}$ range; fruit set is good and flesh color is dark red; stripes are wide, dark green on light green; mid season maturity. Similar: Tri-X-313, A\&C 5244. Adaptation: United States, Mexico, Central America. 2003.

Malali-Vendor: Hazera. Parentage: open-pollinated. Characteristics: 80 days to maturity; 5-6 kg; almost round; olive green with fine stripes; red flesh; $12 \%$ sugar; delicious flavor. Adaptation: U.S. 2002.

Mara-Vendor: United Genetics. Parentage: hybrid diploid. Characteristics: 80 days to maturity; $8-12 \mathrm{~kg}$ oval; light green rind with dark stripes; deep red flesh; 11\% sugar; good shipper. Adaptation: U.S. 2002.

Master Piece 518 - Vendor: Chia Tai Co. Parentage: hybrid diploid. Characteristics: 55-60 days to maturity; 2-4 kg; high round; black rind; red flesh; 12\% sugar; high yield. Adaptation: U.S. 2002.

Mayo-Vendor: Native Seeds. Parentage: open-pollinated. Characteristics: small fruits in different colors; prolific vines. Adaptation: U.S. 2002.

Mayo Sandiia-Vendor: Native Seeds. Parentage: openpollinated. Characteristics: red flesh; small fruits. Adaptation: U.S. 2002.

Melitopolski-Vendor: Seed Savers Exchange. Characteristics: round; red flesh; alternating light and dark green stripes; early ripening; reddish brown seeds. Adaptation: U.S. 2001.

Mid-Night - Vendor: Willhite. Parentage: hybrid-diploid. Characteristics: $80-85$ days to maturity; $7-8 \mathrm{~kg}$; round; dark rind; red flesh; tolerant to Fusarium wilt. Adaptation: U.S. 2003.

Midas Touch-Vendor: Seminis Garden Newsmakers; Fedco Seeds; Holmes Seed Co. Parentage: hybrid diploid. Characteristics: 74-75 days to maturity; 6-7 kg; blocky oval; light green rind with dark green stripes; yellow flesh; tolerant to hollow-heart. Adaptation: U.S. 2002.

Mini-Jubilee-Vendor: Park Seed Parentage: hybrid diploid. Characteristics: 70 days to maturity; 3-4 kg; oblong; deep red flesh; tolerant to powdery mildew, virus. Adaptation: U.S. 2002.

Mini Yellow-Breeder and vendor: D. Palmer Seed Co., Inc. Parentage: hybrid. Characteristics: mini triploid watermelon with yellow flesh; perfect personalize watermelon; ideal for market displays with its attractive appearance and small size; high brix and great taste; features strong plant growth for sunburn protection; can be grown conventionally. Adaptation: U.S. 2005.

Mitha-Vendor: Willhite. Parentage: hybrid diploid. Characteristics: $95-100$ days to maturity; $4-5 \mathrm{~kg}$; round; blackish with lightgreen shading; red flesh; good shipper. Adaptation: U.S. 2002.

Monarch—Vendor: Seed Way. Parentage: hybrid triploid. Characteristics: 90 days to maturity; 8-13 kg; elongated; dark green rind with thin light green stripes; red flesh; tolerant to Fusarium; good shipper. Adaptation: U.S. 2002.

Moon and Stars (Sun, Moon and Stars) - Breeder and vendor: Peter Henderson and Co. Parentage: inbred line. Characteristics: elongate fruit; dark green rind with bright yellow spots on it due to the $S p S p$ genotype; yellow spots on fruit range in size from tiny to several inches across; leaves also have yellow spots; sweet, red flesh; thick rind; brown seeds with black speckles; 95 days to maturity. Adaptation: U.S. 1926.

More 039 - Vendor: Chia Tai Company. Parentage: open-pollinated. Characteristics: $70-75$ days to maturity; 4-5 kg; round; black rind; bright red flesh; 11\% sugar. Adaptation: U.S. 2002.

Mountain Hoosier-Vendor: Willhite. Parentage: open-pollinated. Characteristics: 85 days to maturity; $34-37 \mathrm{~kg}$; slightly oblong; dark green rind; deep red flesh. Adaptation: U.S. 2002.

Mountain Sweet Yellow-Vendor: Seed Savers Exchange. Characteristics: 95-100 days to maturity; long; 14-20 lb; dark yellow flesh; very high sugar content. Adaptation: U.S. 2002.

Navajo Sweet-Vendor: D.V. Burrell Seed Growers. Parentage: open-pollinated. Characteristics: 90 days to maturity; 4-9 kg; round; dark green rind; red flesh; good shipper. Adaptation: U.S. 2002. 
Navajo Winter-Vendor: D.V. Burrell Seed Growers. Parentage: open-pollinated. Characteristics: round; green rind with light stripes; pink to red flesh. Adaptation: U.S. 2002.

New Orchid-Vendor: Johnny's. Parentage: open-pollinated. Characteristics: 80 days to maturity; oval-round; dark green rind with high contrast stripes; orange flesh; tolerant to F1. Adaptation: U.S. 2002.

New Queen-Vendor: Stokes. Parentage: hybrid diploid. Characteristics: 63 days to maturity; $2 \mathrm{~kg}$; oval; striped rind; orange flesh. Adaptation: U.S. 2002.

Oasis 283-Vendor: Chia Tai Company. Parentage: hybrid diploid. Characteristics: $70-75$ days to maturity; 5-8 kg; round; black rind; red flesh; 11\% sugar; vigorous; disease tolerant. Adaptation: U.S. 2002.

Obelik 828-Vendor: Chia Tai Company. Parentage: hybrid diploid. Characteristics: 70-75 days to maturity; $5-8 \mathrm{~kg}$; elongated; light green rind; red flesh; $11 \%$ sugar; crisp with small seeds; excellent shipper. Adaptation: U.S. 2002.

Oberon 205-Vendor: Chia Tai Company. Parentage: hybrid diploid. Characteristics: 75 days to maturity; 5-7 kg; round; green with stripes; light red flesh; $11 \%$ sugar; vigorous vine; disease tolerant. Adaptation: U.S. 2002.

Octopus 335-Vendor: Chia Tai Company. Parentage: hybrid diploid. Characteristics: 70-75 days to maturity; 4-6 kg; round; black rind; red flesh; $11 \%$ sugar; sweet; good market seller. Adaptation: U.S. 2002.

Odem-Vendor: Hazera. Parentage: hybrid diploid. Characteristics: 80 days to maturity; $4-7 \mathrm{~kg}$; oblong; very dark green rind; red flesh; $12 \%$ sugar; tolerant to Fusarium 1; stores well. Adaptation: U.S. 2002 .

Odyssey 173-Vendor: Chia Tai Company. Parentage: openpollinated. Characteristics: 75 days to maturity; $1-2 \mathrm{~kg}$; round; green rind with stripes; light red flesh; 11\% sugar. Adaptation: U.S. 2002.

Offen 230-Vendor: Chia Tai Company. Parentage: openpollinated. Characteristics: 85 days to maturity; $1-2 \mathrm{~kg}$; oblong; light green rind; light red flesh; 12\% sugar. Adaptation: U.S. 2002.

Officer 764-Vendor: Chia Tai Company. Parentage: hybrid diploid. Characteristics: 70-75 days to maturity; 4-6 kg; round; green with stripes; bright red flesh; $12 \%$ sugar; firm flesh; small seeds; good shelf-life. Adaptation: U.S. 2002.

Ohio S1-Vendor: Chia Tai Company. Parentage: hybrid diploid. Characteristics: 70-75 days to maturity; 1-3 kg; round; black rind; red flesh; 11\% sugar. Adaptation: U.S. 2002.

Ohio 002-Vendor: Chia Tai Company. Parentage: hybrid diploid. Characteristics: $70-75$ days to maturity; $6-8 \mathrm{~kg}$; round; black rind; red flesh; 11\% sugar. Adaptation: U.S. 2002.

Okey 508-Vendor: Chia Tai Company. Parentage: hybrid diploid. Characteristics: $70-75$ days to maturity; 5-7 kg; round; green rind with stripes; red flesh; $11 \%$ sugar; early. Adaptation: U.S. 2002.

Ole'-Vendor: Willhite Seed Inc. Parentage: hybrid. Characteristics: 85 days to maturity; 22-25 lb; dark green striped rind; red flesh; uniform; tolerant to Fusarium wilt; small seed. Adaptation: U.S. 2002.

Olympia (PS 11005031) - Breeder and vendor: Seminis Vegetable Seeds-Petoseed. Parentage: triploid F1 hybrid. Characteristics: new seedless type, oval-blocky shape, better internal and external quality, rind has a dark green stripe on a medium green background, bright red flesh, mid season maturity, 18-20 lb fruit, seedlings should be transplanted. Similar: Millionaire. Adaptation: North America, Mexico. 2002.

Olympic 825 - Vendor: Chia Tai Company. Parentage: hybrid diploid. Characteristics: 70-75 days to maturity; 4-6 kg; round; black rind; red flesh; 11\% sugar; high yields; small seed. Adaptation: U.S. 2002.

Omega 666-Vendor: Chia Tai Company. Parentage: hybrid diploid. Characteristics: $70-75$ days to maturity; $6-8 \mathrm{~kg}$; round; light green rind with dark green stripes; red flesh; $12 \%$ sugar; early; very sweet; good shipper. Adaptation: U.S. 2002.

Oneness 830-Vendor: Chia Tai Company. Parentage: hybrid diploid. Characteristics: 70-75 days to maturity; 1-2 kg; round; dark green with stripes; deep yellow flesh; 11\% sugar. Adaptation: U.S 2002.

Opal 189-Vendor: Chia Tai Company. Parentage: hybrid diploid. Characteristics: 80 days to maturity; 6-9 kg; oblong; dark green; bright red flesh; $11 \%$ sugar; disease tolerant; easy to grow. Adaptation: U.S. 2002.

Opera 755-Vendor: Chia Tai Company. Parentage: hybrid diploid. Characteristics: 70 days to maturity; $2-4 \mathrm{~kg}$; short oblong; light green; deep red flesh; 11\% sugar; early; sweet; good shipper. Adaptation: U.S. 2002.

Optima 761 - Vendor: Chia Tai Company. Parentage: openpollinated. Characteristics: $70-75$ days to maturity; $1 \mathrm{~kg}$; round; green with stripes; bright red flesh; 11\% sugar. Adaptation: U.S. 2002.

Orange Julius - Breeder and vendor: D. Palmer Seed Co., Inc. Parentage: hybrid. Characteristics: new orange-flesh triploid watermelon; good shipper; excellent vine vigor; compacted plantings lowering fruit size; interior is very sweet and juicy with a beautiful, rich orange color. Adaptation: U.S. 2005.

Orange Sunshine - Vendor: Sakata. Parentage: hybrid triploid. Characteristics: 85 days to maturity; $7-9 \mathrm{~kg}$; round to slightly oval; medium green rind with dark green stripes; deep orange flesh; good shipper. Adaptation: U.S. 2002.

Orange Flesh Tendersweet-Vendor: Willhite; DeWitt Seed; Heirloom Seeds. Parentage: open-pollinated. Characteristics: 85 days to maturity; 13-22 kg; oblong; dark green with mottled stripe; orange flesh; local market. Adaptation: U.S. 2002.

Orange Sweet-Vendor: US Seedless. Parentage: hybrid triploid. Characteristics: light green rind with dark green stripes; deep orange flesh. Adaptation: U.S. 2002.

Orangeglo-Vendor: Willhite. Parentage: open-pollinated. Characteristics: 85 days to maturity; $23 \mathrm{~kg}$; light green with dark stripes; orange flesh; local market. Adaptation: U.S. 2002.

Orchestra 541 - Vendor: Chia Tai Company. Parentage: hybrid diploid. Characteristics: 80 days to maturity; 5-8 kg; oblong; light green rind; bright red flesh; 11\% sugar; uniform; crisp flesh; good shipper. Adaptation: U.S. 2002.

Orchid 782 - Vendor: Chia Tai Company. Characteristics: 70-75 days to maturity; $3-6 \mathrm{~kg}$; oval; light green with dark green stripes; bright red flesh; 11\% sugar. Adaptation: U.S. 2002.

Oregon G1-Vendor: Chia Tai Company. Characteristics: 80-85 days to maturity; $1-2 \mathrm{~kg}$; oblong; light green rind; light red flesh; 12\% sugar. Adaptation: U.S. 2002.

Organize 070 - Vendor: Chia Tai Company. Parentage: hybrid triploid. Characteristics: 80 days to maturity; $1 \mathrm{~kg}$; round; dark green rind with stripes; yellow flesh; $12 \%$ sugar; disease tolerant. Adaptation: U.S. 2002.

Oriental 170 - Vendor: Chia Tai Company. Parentage: openpollinated. Characteristics: $65-70$ days to maturity; 3-6 kg; globe; dark green rind with stripes; deep red flesh; 11\% sugar; very sweet; popular in market. Adaptation: U.S. 2002.

Orleans 232 - Vendor: Chia Tai Company. Parentage: hybrid diploid. Characteristics: $80-85$ days to maturity; $7-9 \mathrm{~kg}$; oblong; light green rind; light red flesh; $12 \%$ sugar. Adaptation: U.S. 2002 .

Orloff 085-Vendor: Chia Tai Company. Parentage: hybrid triploid. Characteristics: 80 days to maturity; 4-6 kg; round; dark green-black rind; bright red flesh; 13\% sugar; vigorous; disease tolerant; very sweet. Adaptation: U.S. 2002.

Ornament 144 - Vendor: Chia Tai Company. Parentage: hybrid triploid. Characteristics: $75-80$ days to maturity; 5-7 kg; round; green rind with stripes; red flesh; 12\% sugar; vigorous vine; very sweet and crisp. Adaptation: U.S. 2002.

Oscar 279-Vendor: Chia Tai Company. Parentage: hybrid diploid. Characteristics: 70-75 days to maturity; 4-6 kg; round; black rind; bright red flesh; 11\% sugar; vigorous; attractive bright flesh. Adaptation: U.S. 2002.

Osh Kirgizia - Vendor: Seed Savers Exchange. Characteristics: 90-100 days to maturity; $10-15 \mathrm{lb}$; round fruit; light green rind with unique jagged dark green stripes; sweet pink flesh. Adaptation: U.S. 2002. 
Ovaht 361-Vendor: Chia Tai Company. Parentage: hybrid diploid. Characteristics: 70-75 days to maturity; 4-6 kg; round; light green rind with stripes; yellow flesh; 11\% sugar; early; crisp sweet flesh. Adaptation: U.S. 2002.

Ovation 002 - Vendor: Chia Tai Company. Parentage: hybrid triploid. Characteristics: 80 days to maturity; 5-7 kg; round; green with stripes; light red flesh; 13\% sugar; sweet and tender; excellent shipper. Adaptation: U.S. 2002.

Oxford 190-Vendor: Chia Tai Company. Parentage: hybrid diploid. Characteristics: 80 days to maturity; 6-9 kg; oblong; dark green rind with stripes; bright red flesh; $12 \%$ sugar; very vigorous; firm sweet flesh. Adaptation: U.S. 2002.

Paladin-Vendor: Seed Way; Sakata. Parentage: hybrid diploid. Characteristics: 80 days to maturity; $11 \mathrm{~kg}$; blocky; light rind with dark stripes; bright pink-red flesh; tolerant to AN-1(R), FW(R); suited for shipping. Adaptation: U.S. 2002.

Paradise -Vendor: Chesmore Seed Co; Harris Seeds; Harris Moran Seed Co. Parentage: hybrid diploid. Characteristics: 80 days to maturity; $9 \mathrm{~kg}$; blocky; striped; bright red flesh; tolerant to Fw1, An1; early market deliveries. Adaptation: U.S. 2002.

Parker-Vendor: Willhite. Parentage: hybrid diploid. Characteristics: $80-85$ days to maturity; $10-12 \mathrm{~kg}$; blocky; tri-color rind; red flesh; tolerant to Fusarium wilt; commercial and local use. Adaptation: U.S. 2002.

Parks Whopper II-Vendor: Park Seed. Characteristics: 65 days to maturity; $3 \mathrm{~kg}$; thin strong glossy rind; bright red flesh; large yields. Adaptation: U.S. 2002.

Patriot-Vendor: Willhite; DeWitt Seed; Abbott \& Cobb; Siegers Seed Co. Parentage: hybrid diploid. Characteristics: 80-85 days to maturity; 10-12 kg; cylindrical; light green rind with wide medium green stripes; red flesh; tolerant to Fusarium wilt; excellent shipper. Adaptation: U.S. 2002.

Peacock Improved - Vendor: PS Petoseed; Chesmore Seed Co. Parentage: open-pollinated. Characteristics: 90 days to maturity; 9-11 kg; oblong; uniform, dark green tough rind; red flesh; used in Arizona, California; Mexico; long distance shipping. Adaptation: U.S. 2002.

Pilo Lady - Vendor: Takii. Parentage: hybrid diploid. Characteristics: 45 days to maturity; $2 \mathrm{~kg}$; oblong; deep green rind with clear black stripes; bright pinkish red flesh; 12\% sugar. Adaptation: U.S. 2002.

Pinata-Vendor: Willhite. Parentage: hybrid diploid. Characteristics: 85 days to maturity; $10-12 \mathrm{~kg}$; oblong; dark green striped rind; deep red flesh; tolerant to Fusarium wilt; excellent shipper. Adaptation: U.S. 2002.

Plantation Pride - Breeder and vendor: D. Palmer Seed, Co., Inc. Characteristics: a diploid watermelon that makes an excellent pollinator in seedless production fields; weighing between 23 and 25 $\mathrm{lb}$, this hybrid melon features a dark rind with light yellow stripes; seeds are small; lightly fibered flesh and strong rind. Adaptation: U.S. 2002.

Pluto 188 - Vendor: Chia Tai Company. Parentage: hybrid triploid. Characteristics: $75-80$ days to maturity; $5-7 \mathrm{~kg}$; round; light green with dark stripes; deep red flesh; 13\% sugar; sweet and crisp; excellent shipper. Adaptation: U.S. 2002.

Poquito-Breeder and vendor: D. Palmer Seed Co., Inc. Characteristics: new look in seedless watermelon; personal-size melon weighing between 3 and $5 \mathrm{lb}$; ideal for consumers with limited kitchen space; sweet, of good fiber, and attractive. Adaptation: U.S. 2005.

QV585 - Vendor: Sutter Seeds. Parentage: hybrid diploid. Characteristics: 90 days to maturity; 9-12 kg; oblong; light green rind with dark stripes; red flesh; $10 \%$ sugar; tolerant to anthracnose, Fusarium 1; good pollinator. Adaptation: U.S. 2002.

QV764-Vendor: Sutter Seeds. Parentage: hybrid diploid. Characteristics: 90 days to maturity; $8-10 \mathrm{~kg}$; round; dark green rind; red flesh; $10 \%$ sugar; tolerant to anthracnose, Fusarium 1; sunburn tolerant. Adaptation: U.S. 2002.

QV776 - Vendor: Sutter Seeds. Parentage: hybrid diploid. Characteristics: 90 days to maturity; $8-10 \mathrm{~kg}$; round; dark green rind; red flesh; $10 \%$ sugar; tolerant to Fusarium 1; sunburn tolerant. Adaptation: U.S. 2002.
QWD 380 - Breeder and vendor: Sutter Seeds LLC. Characteristics: diploid type quickly yields 25 - to $30-1 \mathrm{~b}$ melons with attractive red flesh within a rind that resists sunburning; works well as a pollinizer and a main crop. 2001.

QWT 443-Breeder and vendor: Sutter Seeds LLC. Parentage: F1 triploid hybrid. Characteristics: seedless; high yield; elongated blocky shape with deep red flesh within a rind that resists sunburning; fruit are $20 \mathrm{lb} 2001$.

Raptor 515-Vendor: Chia Tai Company. Parentage: hybrid diploid. Characteristics: 55-60 days to maturity; 3-4 kg; high round; green rind with stripes; dark red flesh; 14\% sugar; high yield; very sweet. Adaptation: U.S. 2002.

Raspa-Vendor: Willhite Seed Inc. Parentage: hybrid. Characteristics: 80-85 days to maturity; uniform blocky oval shape; 22-24 lb; firm, crispy, red flesh; very productive; tolerant to Fusarium wilt. Adaptation: U.S. 2002.

Rattlesnake - Vendor: Gurney's. Parentage: open-pollinated. Characteristics: 90 days to maturity; 16-18 kg; oval; red flesh. Adaptation: U.S. 2002.

Red Honey-Vendor: Seed Way. Parentage: hybrid diploid. Characteristics: 68 days to maturity; 4-6 kg; round; dark green rind; brilliant red flesh; good shipper. Adaptation: U.S. 2002.

Regency-Vendor: PS Petoseed; Twilley; Seed Way; DeWitt Seed; Siegers Seed Co. Parentage: hybrid diploid. Characteristics: 83 days to maturity; $8-10 \mathrm{~kg}$; oblong; green with medium green stripes; brilliant red firm flesh; tolerant to A-1, F-1; early shipper for markets needing slightly smaller size; good carton pack. Adaptation: U.S. 2002.

Revelation-Vendor: Seed Way. Parentage: hybrid diploid. Characteristics: 85 days to maturity; $6-7 \mathrm{~kg}$; oval-round; small broken dark green stripes over light green rind; red flesh; tolerant to Fusarium. Adaptation: U.S. 2002.

Revere-Vendor: Sunseeds. Parentage: hybrid triploid. Characteristics: 90-95 days to maturity; oblong; 16-22 lb; tolerant to Fusarium wilt race 1; bright red flesh; vigorous vines. Adaptation: U.S. 2002.

Revolution-Breeder and vendor: Sunseeds Co. Parentage: F1 triploid hybrid. Characteristics: elongated variety; deep red interior color; high sugar content; attractive outer appearance; good shipping ability; improved shelflife; blocky, All-sweet type with wide, darkgreen stripes; mid-season maturity (84 days); attractive red flesh; small seed traces; weighs in at 18 to $22 \mathrm{lb}$. Resistance: resists hollow heart; resistant/tolerant to Fusarium wilt race 1. Adaptation: U.S. 2005.

Rio Mayo Sakobari-Vendor: Native Seeds. Parentage: openpollinated. Characteristics: round; red flesh; good in dry seasons; small fruits. Adaptation: U.S. 2002.

Rio San Miguel-Vendor: Native Seeds. Parentage: openpollinated. Characteristics: round; solid green rind; pale red flesh; good in dry seasons; small fruits. Adaptation: U.S. 2002.

Rojo Grande - Vendor: Willhite. Parentage: hybrid. Characteristics: 85 days to maturity; Allsweet type; dark green striped rind; tough, good shipper; firm, sweet red flesh; 22-24 lb; tolerant to Fusarium wilt. Adaptation: U.S. 2002.

Royal Star-Vendor: PS Petoseed; Seed Way; DeWitt Seed; Stokes; Siegers Seed Co. Parentage: hybrid diploid. Characteristics: 84 days to maturity; 9-12 kg; oblong; green rind with medium green stripes; bright red crisp flesh; tolerant to F1; early vigorous hybrid; good shipper. Adaptation: U.S. 2002.

Royal Sweet-Vendor: PS Petoseed; Seed Way; DeWitt Seed; Stokes; Siegers Seed Co. Parentage: hybrid diploid. Characteristics: 85 days to maturity; 9-11 kg; oblong; green rind with medium green stripes; bright red crisp flesh; 12\% sugar; tolerant to A-1, F-1; early; good shipper; vigorous hybrid. Adaptation: U.S. 2002.

Royal Windsor-Vendor: Stokes. Parentage: hybrid diploid. Characteristics: 75 days to maturity; 9-13 kg; oblong blocky; jubilee stripes; red flesh; tolerant to Fusarium race1. Adaptation: U.S. 2002.

Royal Jubilee-Vendor: PS Petoseed; Twilley; Seed Way; DeWitt Seed; Siegers Seed Co. Parentage: hybrid diploid. Characteristics: 95 days to maturity; 11-14 kg; elongated; light green rind with dark green stripes; bright red crisp flesh; tolerant to A-1, F-1; shipping variety; tough rind. Adaptation: U.S. 2002. 
Royalty -Vendor: Rupp Seeds. Parentage: hybrid diploid. Characteristics: $75-80$ days to maturity; $10-12 \mathrm{~kg}$; oblong; green medium stripes; bright red flesh. Adaptation: U.S. 2002.

Ruby - Breeder and vendor: Hollar Seeds. Parentage: hybrid triploid. Characteristics: 85 days to maturity; seedless watermelon; bright stripes don't fade; highest quality bright red flesh; ships and stores well; sugar content is consistently high; weighs about $15 \mathrm{lb}$; tested and approved in several international markets. Resistance: Fusarium wilt, anthracnose. Adaptation: U.S. 2005.

Russian-Vendor: Eastern Native Seed Conservancy. Parentage: open-pollinated. Characteristics: $2-3 \mathrm{~kg}$; round; red flesh; seedy with long keeping qualities. Adaptation: U.S. 2002.

RWM 8036 - Vendor: Seed Way. Parentage: hybrid. Characteristics: 88 days to maturity; $11-12 \mathrm{~kg}$; elongated; allsweet; bright red flesh; tolerant to F, A1; large grower; friendly sangria. Adaptation: U.S. 2002.

RWM 8073-Vendor: Novartis. Parentage: hybrid triploid. Characteristics: oval; wide dark green stripes on medium green rind; red flesh; 11\% sugar. Adaptation: U.S. 2002.

San Juan-Vendor: Native Seeds. Parentage: open-pollinated. Characteristics: $0.5-5 \mathrm{~kg}$; round; from light green to dark green with stripes; yellow to red flesh; edible seeds; fruits sweet; productive. Adaptation: U.S. 2002.

Sapphire-Vendor: Hollar Seeds. Parentage: hybrid triploid. Characteristics: 90 days to maturity; $8-10 \mathrm{~kg}$; globular; dark green stripes on light green; medium red; $12 \%$ sugar; some tolerance to anthracnose; similar to Tri-X313. Adaptation: U.S. 2002.

Sapphire 182 - Vendor: Chia Tai Company. Parentage: hybrid triploid. Characteristics: 70 days to maturity; $1 \mathrm{~kg}$; round; light green rind with dark green stripes; yellow flesh; $12 \%$ sugar; early; very sweet; good shipper. Adaptation: U.S. 2002.

Scaley Bark-Vendor: R.H. Shumway's. Characteristics: 98 days to maturity; long \& cylindrical; crimson flesh; excellent for preserves. Adaptation: U.S. 2002.

Schlecter-Vendor: Eastern Native Seed Conservancy. Parentage: open-pollinated. Characteristics: $2-3 \mathrm{~kg}$; round; red flesh; good flavor and sweetness. Adaptation: U.S. 2002.

Seedless Sangria - Breeder: T. Williams. Vendor: Syngenta Seeds. Parentage: triploid seedless F1 hybrid. Characteristics: red fleshed; Allsweet rind pattern; fruit weight 16-20 lb.; semi-elongate shape. Resistance: Fusarium wilt races 0,1 ; anthracnose race 1. Similar: Revolution. 2001.

Small Shining Light-Vendor: Seed Savers Exchange. Characteristics: 80-90 days to maturity; round fruit; good for high altitudes. Adaptation: U.S. 2001.

Solid Gold-Vendor: Seed Way; Stokes. Parentage: hybrid triploid. Characteristics: 83 days to maturity; $18-20 \mathrm{~kg}$; round; light green rind with dark green stripes; bright yellow flesh. Adaptation: U.S. 2005.

Solitare-Vendor: Seed Way. Parentage: hybrid triploid. Characteristics: 85 days to maturity; 5-7 lb; round; dark green rind with mottle striping; deep red flesh; crisp flesh; high sugars; cuts well. Adaptation: U.S. 2005

Sornram 751 - Vendor: Chia Tai Company. Parentage: hybrid diploid. Characteristics: $75-80$ days to maturity; $1 \mathrm{~kg}$; short oblong; light green with dark green stripes; bright red flesh; 12\% sugar. Adaptation: U.S. 2002.

StarGazer (XPH 6189) - Breeder and vendor: Seminis Vegetable Seeds-Asgrow. Parentage: diploid F1 hybrid. Characteristics: 24-26 lb fruit; Allsweet type fruit with wide dark stripe on light green background and elongate shape; bright red flesh; high yield; uniformly shaped fruit; 85 days to harvest; dark colored, medium size seeds. Resistance: Anthracnose race 1, Fusarium wilt race 1. Similar: Allsweet. Adaptation: U.S.

Stars'n'Stripes-Breeder and vendor: Seminis Vegetable Seeds-Asgrow. Parentage: diploid F1 hybrid. Characteristics: 22$31 \mathrm{lb}$ fruit; wide dark stripe on light green background and elongate shape; uniform red flesh that is firm and very sweet; high yield; thick durable rind for shipping; 85 days to harvest; medium size black seeds. Resistance: Anthracnose race 1, Fusarium wilt race 1. Similar: Allsweet. Adaptation: U.S.
Sterling_-Vendor: Hollar Seeds; Seed Way. Parentage: hybrid triploid. Characteristics: 97 days to maturity; 9-12 kg; blocky oblong; dark green thin stripes on light green rind; deep red flesh; 11\% sugar; some tolerance to Fusarium wilt and anthracnose; unique. Adaptation: U.S. 2002.

Stokes Sugar Hybrid-Vendor: Stokes. Parentage: hybrid diploid. Characteristics: 70 days to maturity; $6 \mathrm{~kg}$; oblong; medium green rind; deep rose flesh. Adaptation: U.S. 2002.

Strawberry-Vendor: Southern Exposure Seed Exchange. Characteristics: 85 days to maturity; strawberry-red flesh; long fruit; dark green rind with darker green stripes; 15-25 lb; disease resistance is very good. Adaptation: U.S. 1989.

Striped Sugar - Vendor: Takii Seed. Parentage: hybrid diploid. Characteristics: 35 days to maturity; $1 \mathrm{~kg}$; round; dark green stipes; bright red flesh; good transporter. Adaptation: U.S. 2002.

Sugar Shack-Vendor: Sugar Creek Seed, Inc. Parentage: hybrid triploid. Characteristics: 85 days to maturity; oval; broad green stripes over light green rind; dark red, crisp flesh. Adaptation: U.S. 2002.

Sugar Slice-Vendor: Willhite. Parentage: hybrid triploid. Characteristics: 85 days to maturity; slightly oval; $15-18 \mathrm{lb}$; wilt tolerant; excellent red flesh. Adaptation: U.S. 2003.

Sugar Time-Vendor: Sugar Creek Seed, Inc. Parentage: hybrid triploid. Characteristics: 85 days to maturity; oval; broad green stipes over light green rind; dark red, crisp flesh. Adaptation: U.S. 2002.

Sugarheart-Breeder and vendor: Siegers Seed Company. Characteristics: triploid crimson sweet watermelon; oval; bright red flesh; excellent uniformity; outstanding internal and external quality; high yields; fruit weigh between 16 and $20 \mathrm{lb}$; matures in about 85 days from transplant. Resistance: tolerant to hollow heart. Adaptation: widely adapted. 2005.

Summer Flavor \#400-Vendor: Twilley; Abbott \& Cobb. Parentage: hybrid diploid. Characteristics: 85 days to maturity; $11 \mathrm{~kg}$; blocky oblong; medium green broad dark stripes; bright red flesh; long and short distance shipping; fresh market home garden. Adaptation: U.S. 2002.

Summer Flavor \#420-Vendor: Twilley; Abbott \& Cobb. Parentage: hybrid diploid. Characteristics: 87 days to maturity; 10-11 kg; blocky oblong; medium green broad dark stripes; bright red flesh; $11 \%$ sugar; long and short distance shipping; fresh market home garden. Adaptation: U.S. 2002.

Summer Flavor \#500-Vendor: Twilley; Abbott \& Cobb. Parentage: hybrid diploid. Characteristics: 88 days to maturity; 11-14 kg; blocky oblong; medium green broad dark stripes; bright red flesh; $12 \%$ sugar; long and short distance shipping; fresh market home garden. Adaptation: U.S. 2002.

Summer Flavor \#510-Vendor: Twilley; Abbott \& Cobb. Parentage: hybrid diploid. Characteristics: 84 days to maturity; $11 \mathrm{~kg}$; oblong; medium green broad dark stripes; deep red flesh; $11 \%$ sugar; long and short distance shipping; fresh market home garden. Adaptation: U.S. 2002.

Summer Flavor \#700-Vendor: Twilley; Abbott \& Cobb. Parentage: hybrid diploid. Characteristics: 85 days to maturity; 10-13 kg; blocky oblong; light green narrow dark stripes; bright red flesh; 11\% sugar; long and short distance shipping; fresh market home garden. Adaptation: U.S. 2002.

Summer Flavor 710 - Breeder and vendor: Otis S. Twilley. Parentage: F1 diploid hybrid. Characteristics: fruit size large, $30 \mathrm{lb}$; fruit are blocky to oblong, maturing in approximately 85 days; plants medium size, with very strong vines; light green narrow dark stripes; bright red flesh; $10 \%$ sugar. Resistance: Fusarium race 1 and anthracnose race 1. Adaptation: U.S. 2002.

Summer Flavor \#790HQ - Breeder and vendor: Abbott \& Cobb Inc. Characteristics: blocky, oblong watermelon with deep-red flesh color; this allsweet type melon is dark green with lighter green stripes; plant has a large, strong vine with good yields; excellent pollenizer for triploid production. Resistance: Anthracnose 1. Adaptation: U.S. 2005.

Summer Flavor \#800-Vendor: Twilley; Abbott \& Cobb. Parentage: hybrid diploid. Characteristics: 87 days to maturity; 
10-12 kg; blocky oblong; dark green stipes; deep red flesh; $12 \%$ sugar. Adaptation: U.S. 2002.

Summer Flavor \#810-Vendor: Twilley; Abbott \& Cobb. Parentage: hybrid diploid. Characteristics: 88 days to maturity; 11-13 kg; elongated blocky; dark green stripes; deep red flesh; 11\% sugar. Adaptation: U.S. 2002.

Summer Flavor \#820-Vendor: Twilley; Abbott \& Cobb. Parentage: hybrid diploid. Characteristics: 88 days to maturity; 11-13 kg; elongated blocky; dark green stripes; deep red flesh; $12 \%$ sugar. Adaptation: U.S. 2002.

Summer Flavor \#900-Vendor: Twilley; Abbott \& Cobb. Parentage: hybrid diploid. Characteristics: 86 days to maturity; 11-13 kg; elongated; dark green stripes; deep red flesh; 12\% sugar. Adaptation: U.S. 2002.

Summer Flavor \#910-Vendor: Twilley; Abbott \& Cobb. Parentage: hybrid diploid. Characteristics: 86 days to maturity; 10-12 kg; elongated; dark green stripes; deep red flesh; $10 \%$ sugar. Adaptation: U.S. 2002.

Summer Gold-Vendor: Willhite; DeWitt Seed. Parentage: hybrid diploid. Characteristics: $80-85$ days to maturity; oblong; dark green and mottled light green stripes; yellow flesh; tolerant to Fusarium wilt; good shipper. Adaptation: U.S. 2002.

Summer Rich-Vendor: Takii Seed. Parentage: hybrid diploid. Characteristics: 38 days to maturity; $0.5 \mathrm{~kg}$; oval; yellow rind; pink-red flesh; 11\% sugar; not a good transporter. Adaptation: U.S. 2002

Summer Sweet \#3731-Vendor: Abbott \& Cobb. Parentage: hybrid diploid. Characteristics: 90 days to maturity; 6-9 kg; oval; medium red flesh; $11 \%$ sugar; disease tolerant; high quality shipper. Adaptation: U.S. 2002.

Summer Sweet 5244 - Breeder and vendor: Abbott \& Cobb. Parentage: F1 triploid hybrid. Characteristics: seedless fruit weigh 14 to $18 \mathrm{lb}$, with dark-green stripes and limited light green background; fruit are oblong with bright-red flesh; mature in 90 days; good vigor; consistent yields; $12 \%$ sugar; high quality shipper. Resistance: Anthracnose race 1. Adaptation: U.S. 2001.

Summer Sweet \#5544-Vendor: Abbott \& Cobb. Parentage: hybrid triploid. Characteristics: 90 days to maturity; 6-9 kg; oval; dark red flesh; disease tolerant; high quality shipper. Adaptation: U.S. 2002.

Sun, Moon and Stars (Moon and Stars) -Parentage: inbred line. Characteristics: elongate fruit; dark green rind with bright yellow spots on it due to the $S p S p$ genotype; yellow spots on fruit range in size from tiny to several inches across; leaves also have yellow spots; sweet, red flesh; thick rind; brown seeds with black speckles; 95 days to maturity. Adaptation: U.S.

Sunday Special (EMR507) - Vendor: Harris Seeds. Parentage: hybrid triploid. Characteristics: 85 days to maturity; $6-10 \mathrm{~kg}$; roundoval; bright green with dark green stripes; yellow flesh; tolerant to F1. Adaptation: U.S. 2002.

Sunny-Vendor: Willhite. Parentage: hybrid triploid. Characteristics: 85 days to maturity; $16-20 \mathrm{lb}$; yellow gold flesh; very sweet taste; striped rind similar to Allsweet; round oval shape; tolerant to Fusarium wilt. Adaptation: U.S. 2002.

Sunshine — Vendor: Johnny's. Parentage: open-pollinated. Characteristics: 75 days to maturity; $3-5 \mathrm{~kg}$; oval round; bright green rind with dark green stripes; yellow flesh; tolerant to F1. Adaptation: U.S. 2002.

Sun Ray-Vendor: Nunhems. Parentage: hybrid triploid. Characteristics: $83-85$ days to maturity; $13-17 \mathrm{lb}$; round/oval; light green with medium green stripes; orange flesh; $11-12 \%$ sugar content; resists hollowheart; long shelf life; good shipper. Adaptation: U.S. 2005.

Super Crisp-Vendor: Zeraim Gedera. Parentage: hybrid triploid. Characteristics: 85 days to maturity; 16-20 lb; oval; medium green with light green, mottled stripes; brilliant red flesh. Adaptation: U.S. 2002.

Super Gold-Vendor: Willhite. Parentage: hybrid diploid. Characteristics: 80-85 days to maturity; $12 \mathrm{~kg}$; oblong; dark green rind with mottled stripe or light green; yellow flesh; tolerant to Fusarium wilt; good shipper. Adaptation: U.S. 2002.
Super Seedless-Vendor: Abbott \& Cobb. Parentage: hybrid triploid. Characteristics: oval/blocky; $14-18 \mathrm{lb}$; dark green stripes; crisp, bright red flesh. Adaptation: U.S. 2002.

Super Seedless \#7167-Breeder and vendor: Abbott \& Cobb Inc. Characteristics: dark green background; medium green stripes; offers potential for superior field performance over conventional seedless watermelon varieties; tests show this variety has more vigor, vine development, fruit set, better fruit quality, and the highest yield potential available in a seedless-type watermelon. Resistance: Anthracnose 1. Adaptation: U.S. 2005.

Super Seedless Variety \#7187-Breeder and vendor: Abbott \& Cobb Inc. Characteristics: high quality Super Seedless triploid watermelon with an interior like none before it; yield suits the grower, while internal quality pleases the shipper and consumer; excellent choice for seedless prog. Resistance: Anthracnose 1. 2005.

Super Top-Vendor: Sakata. Parentage: hybrid diploid. Characteristics: 83 days to maturity; $10 \mathrm{~kg}$; elongated; light green rind; deep red flesh; tolerant to AN-1(R), FW(T). Adaptation: U.S. 2002.

Supercool-Vendor: Ultimate Seeds Inc. Parentage: hybrid triploid. Characteristics: 83 days to maturity; $8-11 \mathrm{~kg}$; round to slightly oblong; medium green rind with darker green stripes; deep red flesh; consistent performer with high commercial potential. Adaptation: U.S. 2002.

SuperSweet \#2532 - Vendor: Twilley; Abbott \& Cobb. Parentage: hybrid triploid. Characteristics: 90 days to maturity; 5-7 kg; round; dark stripe pattern on light green rind; bright red flesh, crisp, no seed; fresh market. Adaptation: U.S. 2002.

SuperSweet \#3521Y - Vendor: Twilley; Abbot \& Cobb. Parentage: hybrid triploid. Characteristics: 88 days to maturity; $5-6 \mathrm{~kg}$, round; dark stripe pattern on light green rind; crisp, pure yellow flesh, very bright, no seed; fresh market. Adaptation: U.S. 2002.

SuperSweet \#5032 - Vendor: Twilley; Abbot \& Cobb. Parentage: hybrid triploid. Characteristics: 90 days to maturity; 5-7 kg; round; light green rind with dark green stripe; bright red flesh, medium fine crisp texture, no seed; fresh market. Adaptation: U.S. 2002.

SuperSweet \#5244 — Vendor: Twilley; Abbot \& Cobb. Parentage: hybrid triploid. Characteristics: 90 days to maturity; $6-8 \mathrm{~kg}$; oblong; light green rind with dark green stripe; brith red flesh, fine and crisp, no seed; fresh market. Adaptation: U.S. 2002.

SuperSweet \#5544 - Vendor: Twilley; Abbot \& Cobb. Parentage: hybrid triploid. Characteristics: 88 days to maturity; $6-8 \mathrm{~kg}$; wide light green rind with dark green stripe; fresh market. Adaptation: U.S. 2002

SW-6008-Vendor: Hazera. Parentage: hybrid triploid. Characteristics: 75 days to maturity; $1.5-2.5 \mathrm{~kg}$; round; dark green rind with lighter green stripes; red flesh; adapted to high planting density. Adaptation: U.S. 2002.

Sweet Amigo - Vendor: Seed Way. Parentage: hybrid. Characteristics: 88 days to maturity; $10-11 \mathrm{~kg}$; elongated; allsweet type; dark red flesh; excellent pollinator for seedless. Adaptation: U.S. 2002.

Sweet Boy 176-Vendor: Chia Tai Co. Parentage: hybrid diploid. Characteristics: 80 days to maturity; 7-9 kg; oblong; dark green; light red flesh; 11\% sugar; fast growing; disease tolerant. Adaptation: U.S. 2002

Sweet Caroline Improved-Vendor: D. Palmer Seed Co. Parentage: hybrid triploid. Characteristics: 90 days to maturity; light green rind with dark green mottled stripes; bright red flesh; very sweet; good shipper; tolerant to Fusarium wilt and anthracnose; seedless; high yielding potential. Adaptation: U.S. 2002.

Sweet Delight-Breeder and vendor: Syngenta Seeds, Inc./ Rogers Brand. Parentage: hybrid triploid. Characteristics: 86 days to maturity; $17-20 \mathrm{lb}$; fruit was consistently from 2 to $3 \mathrm{lb}$ larger than TRI-X ${ }^{\circledR}$ Brand 313 types; light green rind with mottled dark green stripes; fruit are oval in shape with bright red flesh color and excellent uniformity of fruit shape; very good fruit set. Similar: TRI-X® Brand 313. Adaptation: U.S. 2005.

Sweet Dream 758 - Vendor: Chia Tai Co. Parentage: hybrid diploid. Characteristics: 70-75 days to maturity; 4-6 kg; round; 
green with stripes; bright red flesh; 11\% sugar; vigorous; uniform; high fruit setting. Adaptation: U.S. 2002.

Sweet Eat'n-Breeder and vendor: D. Palmer Seed Co., Inc. Parentage: hybrid. Characteristics: triploid watermelon; Tri-X 313 type; exceptionally high producer; high fiber content; excellent shipper; strong brix, dark-red flesh; great flavor; high producer. Adaptation: U.S. 2005

Sweet Favorite-Vendor: Twilley; Johnny's; Stokes; Henry Fields; Sakata. Parentage: hybrid diploid. Characteristics: 82 days to maturity; $9 \mathrm{~kg}$; oblong; dark and light green stiped; red flesh; big yields; short distance shipping; fresh market; home garden. Adaptation: U.S. 2002.

Sweet Girl 175 — Vendor: Chia Tai Co. Characteristics: 75 days to maturity; 1-2 kg; short oblong; light green rind; bright red flesh; 12\% sugar; good shipper. Adaptation: U.S. 2002.

Sweet Marvel-Vendor: Takii Seed. Parentage: hybrid diploid. Characteristics: 45 days to maturity; $1 \mathrm{~kg}$; globe; dark green with blackgreen stripes; pink-red flesh; $12 \%$ sugar; high tolerant to A, F, leaf blight, and downy mildew; good transporter. Adaptation: U.S. 2002.

Sweet Siberian-Vendor: Seed Savers Exchange. Characteristics: medium sized; light green rind; oblong; $8 \mathrm{lb}$; sweet juicy bright yellow flesh; 80-85 days to maturity. Adaptation: U.S. 2002.

Sweet Slice-Vendor: Willhite Seed Inc. Parentage: hybrid triploid. Characteristics: 85 days to maturity; oval; $14-20 \mathrm{lb}$; wilt tolerant; bright red flesh. Adaptation: U.S. 2003.

SWD 8307-Vendor: Seed Way; Sakata. Parentage: hybrid diploid. Characteristics: 83 days to maturity; 19-22 lb; blocky; medium green rind with dark green, broad mottled stripes; deep red flesh; little bottlenecking; moderate resistance to Fusarium race 1. Adaptation: U.S. 2005.

SWM 2301 - Vendor: Sakata. Parentage: hybrid diploid. Characteristics: 85 days to maturity; 9-12 kg; 9-11 kg; blocky; light green rind with dark green stripes; rosy red flesh; tolerant to $\mathrm{AN}(\mathrm{T})$, F(T). Adaptation: U.S. 2002.

SWT 6703 - Vendor: Sakata. Parentage: hybrid triploid. Characteristics: round; narrow medium green stripes on light green rind; red flesh; 11\% sugar. Adaptation: U.S. 2002.

SWT 6903 (95-11) - Vendor: Sakata. Parentage: hybrid triploid. Characteristics: $82-85$ days to maturity; $6-8 \mathrm{~kg}$; round; thin dark green stripes on light green background; red flesh; 11\% sugar; tolerant to AN-1(T). Adaptation: U.S. 2002.

SWT 8705-Vendor: Sakata. Parentage: hybrid triploid. Characteristics: 90 days to maturity; $6-8 \mathrm{~kg}$; blocky, oval; sturdy rind with dark green stripes; intense red flesh. Adaptation: U.S. 2002.

SXW 4016 - Vendor: Sunseed. Parentage: hybrid triploid. Characteristics: blocky; light green stripes on dark green rind; red flesh; 11\% sugar. Adaptation: U.S. 2002.

SXW 5023-Vendor: Sunseeds. Parentage: hybrid diploid. Characteristics: $80-85$ days to maturity; $18-22 \mathrm{lb}$; blocky; tolerant to F-1; wide dark green stripes over light green background; high sugar content; excellent shipper; resists hollowheart. Adaptation: U.S. 2002

SXW 5038-Vendor: Sunseeds. Parentage: hybrid diploid. Characteristics: $80-85$ days to maturity; $26-30 \mathrm{lb}$; elongated tolerant to F-1; wide dark green stripes on light green background; excellent shipper; resists hollowheart. Adaptation: U.S. 2002.

SXW 5040 - Vendor: Sunseeds. Parentage: hybrid diploid. Characteristics: $80-85$ days to maturity; $22-26 \mathrm{lb}$; round to oval; tolerant to F-1; dark red flesh; resistant to hollowheart. Adaptation: U.S. 2002

SX 8035WM-Vendor: Sunseeds. Parentage: hybrid triploid. Characteristics: midseason maturity; round; 9-13 lb; dark green rind with no stripes; $12-13 \%$ sugars; bright red flesh. Adaptation: U.S 2005

Talladega-Vendor: Sakata. Parentage: hybrid triploid. Characteristics: 90 days to maturity; 14-18 lb; blocky/oval; medium green rind with light green stripes; bright red flesh; consistent yields. Adaptation: U.S. 2005.

Tastigold-Vendor: Willhite. Parentage: open-pollinated. Characteristics: 80 days to maturity; $10-11 \mathrm{~kg}$; round; gray rind; yellow flesh; wilt tolerant. Adaptation: U.S. 2002.
Tiger 180 -Vendor: Chia Tai. Parentage: open-pollinated. Characteristics: $70-75$ days to maturity; $1-2 \mathrm{~kg}$; round; green with dark green stripes; light red flesh; 12\% sugar. Adaptation: U.S. 2002.

Tiger Baby-Vendor: PS Petoseed; Twilley; Seed Way; Stokes; Park Seed. Parentage: hybrid diploid. Characteristics: 80 days to maturity; $3-5 \mathrm{~kg}$; round to slightly oval; dark green stripes on graygreen; pinkish-red dense sweet flesh; $12 \%$ sugar; tolerant to A-1, F-1; uniform; excellent fruit holding and shipping. Adaptation: U.S 2002.

Tohono O'odham Yellow-Vendor: Native Seeds. Parentage: open-pollinated. Characteristics: 9-17 kg; oval; yellow to orange flesh; sweet and crisp. Adaptation: U.S. 2002.

Tom 004-Vendor: Chia Tai. Parentage: hybrid diploid. Characteristics: 55-60 days to maturity; 4-6 kg; oblong; black rind; dark red flesh; 12\% sugar; very sweet. Adaptation: U.S. 2002.

Tong 810 - Vendor: Chia Tai. Parentage: hybrid diploid. Characteristics: $70-75$ days to maturity; $3-5 \mathrm{~kg}$; elongated; yellow rind; red flesh; $11 \%$ sugar; disease tolerant; uniform; small seed. Adaptation: U.S. 2002.

Top Yield-Vendor: Twilley; Abbott \& Cobb. Parentage: hybrid diploid. Characteristics: 80 days to maturity; $11-16 \mathrm{~kg}$; large oblong; gray green thick rind; red flesh; commercial shipping. Adaptation: U.S. 2002.

Topaz - Vendor: Hollar Seeds. Parentage: hybrid triploid. Characteristics: 87 days to maturity; 5-7 kg; globular; narrow stripe on light green; dark red flesh; some tolerance to anthracnose. Similar: Boston and Queen of Hearts. Adaptation: U.S. 2002.

Top Gun - Vendor: Syngenta. Parentage: hybrid diploid. Characteristics: 83 days to maturity; 21-24 lb; globe; medium green rind with broad, medium dark green stripes; bright red flesh; tolerant to $\mathrm{A}(\mathrm{t}), \mathrm{F}(\mathrm{T})$; excellent seedling vigor. Adaptation: U.S. 2005.

Treasure Chest - Vendor: Seed Way. Parentage: hybrid triploid. Characteristics: 88 days to maturity; 6-7 kg; oval; light green rind with broad green stripes; golden yellow flesh. Adaptation: U.S. 2002

TRI-X ${ }^{\circledR}$ Brand Palomar-Breeder and vendor: Syngenta Seeds, Inc./Rogers Brand. Parentage: hybrid triploid. Characteristics: 88 days to maturity; $6-8 \mathrm{~kg}$; round; medium green rind with narrow dark stripes; firm, crisp, solid flesh is bright-red in color and is wrapped with a unique rind pattern which can be identified by growers and consumers; 11\% sugar; excellent yield potential with high fruit setting ability and improved fruit arrivals due to the firm flesh. Resistance: tolerant to Fusarium race 1. Adaptation: U.S. 2005.

Tri-X Carousel-Breeder and vendor: Novartis Seeds, Inc. Parentage: hybrid triploid. Characteristics: light green rind with distinctive broad green stripes outside and crisp, sweet red flesh inside; maturing approximately 85 days from planting, this high yielding hybrid delivers oval-shaped fruit weighing 16 to $19 \mathrm{lb} ; 12 \%$ sugar; good shipper. Resistance: tolerant to Fusarium race 1. Adaptation: U.S. 1998.

Tri-X Chiffon-Parentage: hybrid triploid. Characteristics: 90 days to maturity; 4-5 kg; round; green with light green stripes; bright yellow flesh; good shipper. Adaptation: U.S. 2002.

Tri-X Shadow-Parentage: hybrid triploid. Characteristics: late main season; 6-7 kg; round to oval; green rind with dark green stripes red flesh; 11\% sugar; excellent shipper. Adaptation: U.S. 2002.

Tri-X Sunrise - Parentage: hybrid triploid. Characteristics: main season; 8-9 kg; round to oval; jubilee stripes; bright red flesh; superior shipping qualities. Adaptation: U.S. 2002.

Tri-X Triple Sweet-Parentage: hybrid triploid. Characteristics: 85 days to maturity; $7-8 \mathrm{~kg}$; round; mottled stripes crimson type stripe; red flesh. Adaptation: U.S. 2002.

Tri-X 313-Vendor: Seed Way. Parentage: hybrid triploid. Characteristics: 85 days to maturity; $15-18 \mathrm{lb}$; oval; light green rind with mottled dark green stripes; red flesh; seedless; good shelf life. Adaptation: U.S. 2005.

Tri-X 626-Parentage: hybrid triploid. Characteristics: early main season; 6-7 kg; round; dark green rind; red flesh. Adaptation U.S. 2002.

Triple Crown-Vendor: Seed Way. Parentage: hybrid triploid. Characteristics: 85 days to maturity; 7-8 kg; oval; light green rind with broad green stripes; red flesh. Adaptation: U.S. 2005. 
Triple Prize - Vendor: Seed Way. Parentage: hybrid triploid. Characteristics: 85 days to maturity; $7-8 \mathrm{~kg}$; oval; light green rind with dark green; red flesh. Adaptation: U.S. 2002.

Triplesweet F1-Vendor: Harris Seeds. Parentage: openpollinated. Characteristics: 85 days to maturity; $7-9 \mathrm{~kg}$; nearly round; light green with dark green stipes; pink-red flesh; crisp; seedless; good shipping. Adaptation: U.S. 2002.

Ultracool-Vendor: Ultimate Seeds Inc. Parentage: hybrid triploid. Characteristics: 75 days to maturity; $6-8 \mathrm{~kg}$; round; light green with narrow darker stripes; sweet bright red flesh; long-lasting vines for high yields. Adaptation: U.S. 2002.

USX-1-Vendor: Ultimate Seeds Inc. Parentage: hybrid triploid. Characteristics: 85 days to maturity; 9-11 kg; elongated; dark green rind with light stripes; red flesh. Adaptation: U.S. 2002.

Vagabond (HMX 8913) - Breeder and Vendor: Harris Moran. Characteristics: 13-16 lb. triploid packs in flavor within its firm, dark-red, juicy flesh; early season variety suitable for fresh cut; good brix, oval shape stacks easily. Resistance: intermediate resistance to Anthracnose. 2005.

Valdoria-Vendor: Nunhems. Parentage: hybrid diploid. Characteristics: 80 days to maturity; 7-9 kg; oblong; dark green; light red flesh; 11\% sugar; fast growing; disease tolerant. Adaptation: U.S. 2002.

Valentine-Vendor: Seed Way. Characteristics: personal-size; seedless; bright red flesh. Adaptation: U.S. 2004.

Vampiro (SSC 31790 \& SSC 1428)-Breeder: Sutter Seeds. Vendor: Shamrock Seed Co. Parentage: F1 hybrid; synonym Verde Grande. Characteristics: diploid hybrid; blocky-oblong fruit with a solid, dark green rind and red flesh; high yield of fruit weighing $20 \mathrm{lb}$; widely adapted; high quality fruit; 80 days to maturity. Similar: Peacock. Adaptation: U.S. watermelon areas. 2004.

Vanessa-Vendor: Seed Way. Parentage: hybrid triploid. Characteristics: 80-85 days to maturity; 5-7 lb; round; black rind; deep red flesh; seedless; compare to Sugar Baby; thin rind. Adaptation: U.S. 2005.

Veracruz-Vendor: Hollar Seeds. Parentage: open-pollinated. Characteristics: 87 days to maturity; $2-3 \mathrm{~kg}$; elongated; green stripe on green rind; dark red flesh. Adaptation: U.S. 2002.

Verde Grande - Vendor: D. Palmer Seed Co. Parentage: hybrid diploid. Characteristics: dark green rind; elongated smooth fruit; bright red, crispy, sweet flesh; 25-30 lb; tolerant to hollow heart. Adaptation: U.S. 2002.

Vista-Vendor: Hollar Seeds; Seed Way Parentage: hybrid diploid. Characteristics: 80 days to maturity; 9-11 kg; blocky oblong; light green with narrow dark green stripes; dark red flesh; some tolerance to Fusarium wilt and anthracnose; compare to Oasis. Adaptation: U.S. 2005.

Winter Melon (King \& Queen)—Vendor: R.H. Shumway's. Parentage: open-pollinated. Characteristics: 80 days to maturity; 7-9 kg; globe; greenish-white rind with yellow stripes; pink-red flesh; stores well. Adaptation: U.S. 2002.
WM8003 - Vendor: Zeraim Gadera. Parentage: hybrid triploid. Characteristics: 85 days to maturity; $6-10 \mathrm{~kg}$; oval; light green rind with dark green stripes; red flesh; 11\% sugar; crimson type. Adaptation: U.S. 2002.

WM8006 - Vendor: Zeraim Gadera. Parentage: hybrid triploid. Characteristics: 85 days to maturity; 6-10 kg; oval; light green with dark green stripes; red flesh; 11\% sugar. Adaptation: U.S. 2002.

Wonder (HA 5109) - Breeder and vendor: Siegers Seed Company. Characteristics: sweet mini triploid watermelon that delivers uniform size with consistently firm, high-quality flesh; ideal rind thickness; good yields; dark-green rind, round shape, weighs only $31 / 2$ to $51 / 2$ lb. Adaptation: U.S. 2005.

Wrigley-Vendor: Asgrow. Parentage: hybrid triploid. Characteristics: 90 days to maturity; 7-9 kg; oval; light green with dark green stripes; red flesh; 12\% sugar. Adaptation: U.S. 2002.

XWT 7701 - Vendor: Sakata. Parentage: hybrid triploid. Characteristics: oval; dark green stripes on light green rind; red flesh; $11 \%$ sugar. Adaptation: U.S. 2002.

XWT 7702 - Vendor: Sakata. Parentage: hybrid triploid. Characteristics: round; medium green stripes on light green rind; red flesh; 11\% sugar. Adaptation: U.S. 2002.

XWT 7703 - Vendor: Sakata. Parentage: hybrid triploid. Characteristics: oval/blocky; dark green stripes on light to medium green rind; red flesh; 11\% sugar. Adaptation: U.S. 2002.

Yellow Baby-Vendor: Stokes; Harris Seeds. Parentage: hybrid diploid. Characteristics: 4-5 kg; round; light green with dark green stripes; yellow flesh. Adaptation: U.S. 2002.

Yellow Belly Black Diamond-Vendor: Willhite; DeWitt Seed. Parentage: open-pollinated. Characteristics: 90 days to maturity; 27-35 kg; slight oblong; blue-black with yellow belly; bright red flesh. Adaptation: U.S. 2002.

Yellow Crimson-Vendor: Willhite. Parentage: open-pollinated. Characteristics: 80 days to maturity; $12 \mathrm{~kg}$; round; striped rind; bright yellow flesh. Adaptation: U.S. 2002.

Yellow Cutie-Vendor: Sakata. Parentage: hybrid diploid. Characteristics: 68 days to maturity; $1 \mathrm{~kg}$; round to oval; light green rind with dark stripes; lemon yellow flesh; local market. Adaptation: U.S. 2002.

Yellow Flesh Black Diamond-Vendor: Willhite. Characteristics: 90 days to maturity; 60-70 lb; glossy dark green rind; yellow flesh; good shipper. Adaptation: U.S. 2002.

Young Beauty 1000 - Vendor: Chia Tai Co. Characteristics: 35-40 days to maturity; $0.12 \mathrm{~kg}$; high round; green rind. Adaptation: U.S. 2002.

Young Boy 1001 - Vendor: Chia Tai Co. Characteristics: 40-45 days to maturity; $0.3 \mathrm{~kg}$; oblong; light green rind; good for packing. Adaptation: U.S. 2002.

Young Girl 1002 - Vendor: Chia Tai Co. Characteristics: 35-40 days to maturity; $0.12 \mathrm{~kg}$; oval; light green rind with dark stripes. Adaptation: U.S. 2002. 